
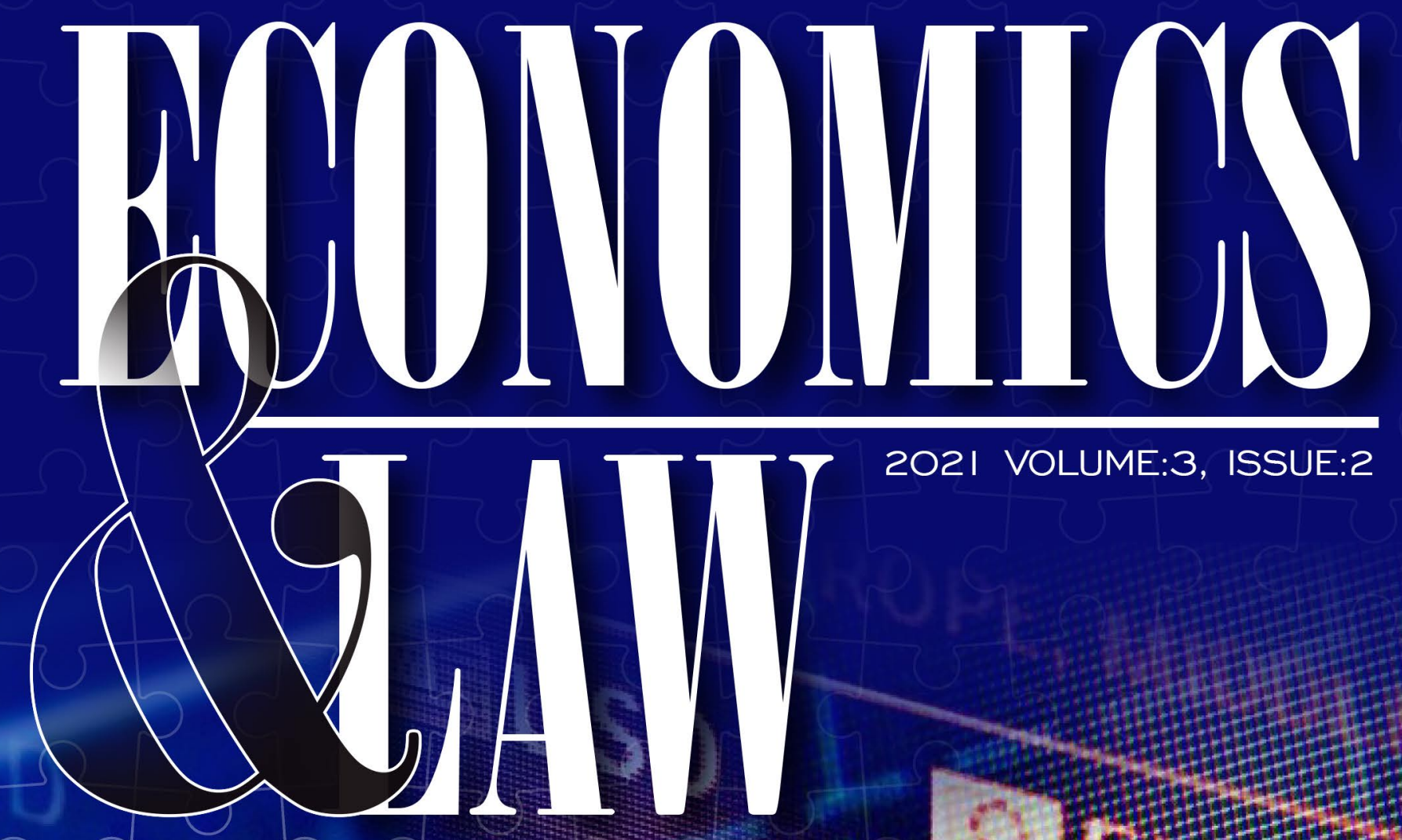

202I VOLUME:3, ISSUE:2

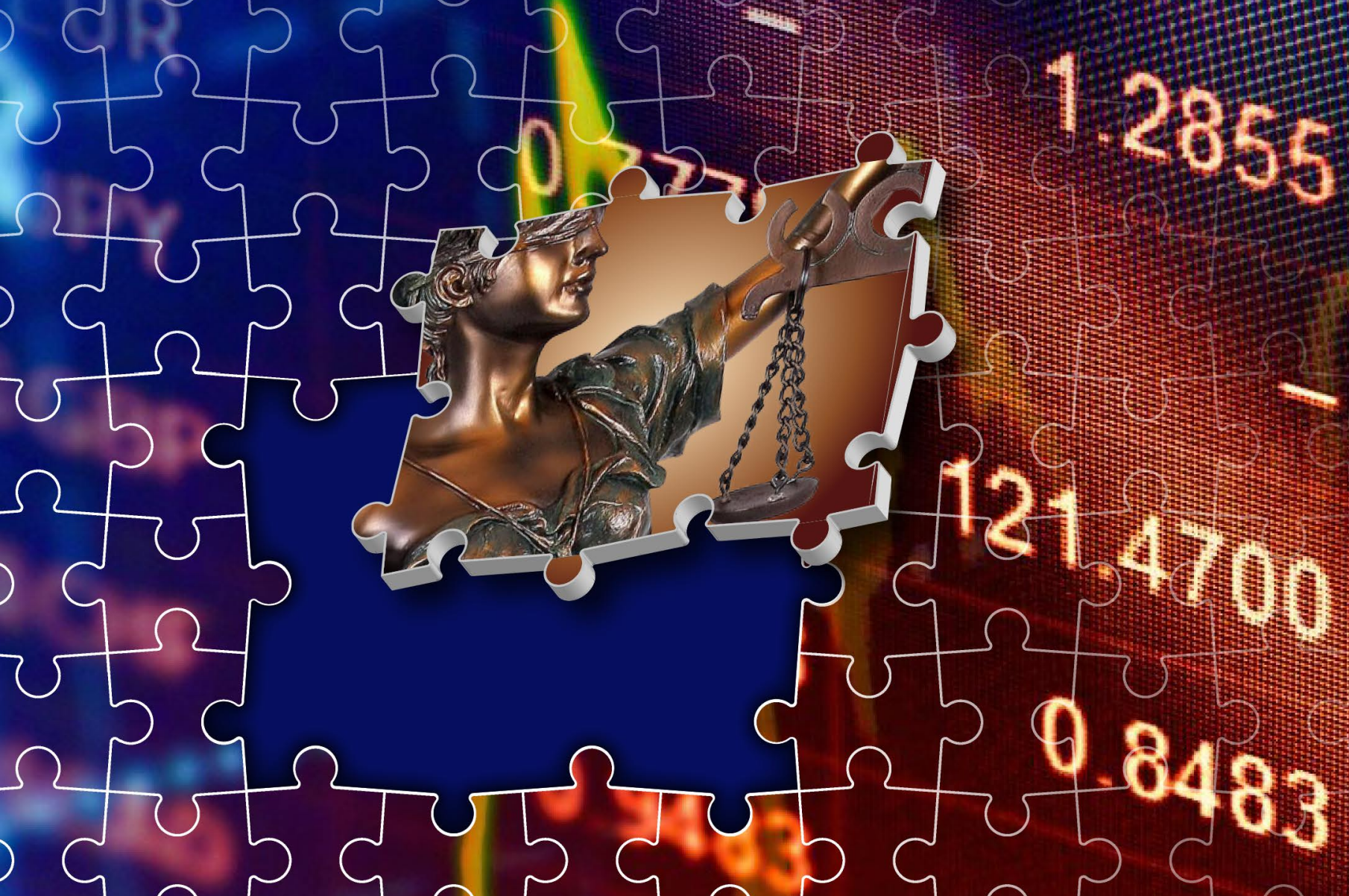

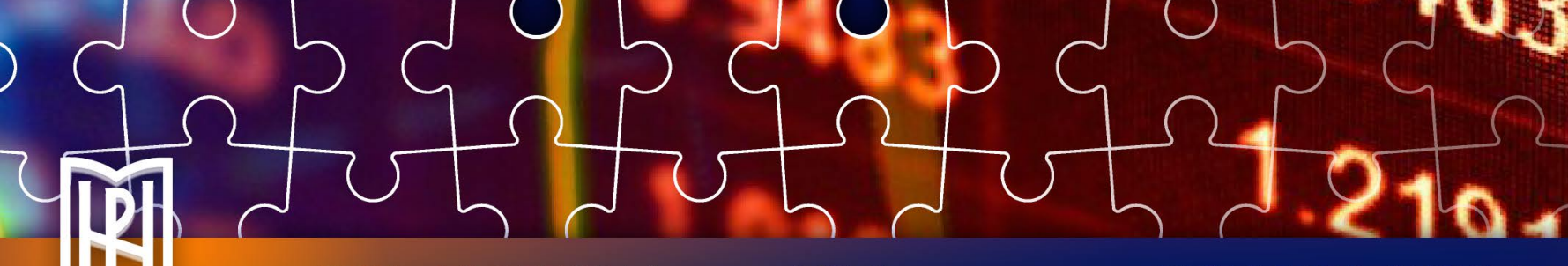

DOI: 10.37708/el.swu.v3i2.0

ISSN 2682-972X (ONLINE) 


\section{$\underline{\text { Editor-in-Chief }}$}

Maria Kicheva, SWU “Neofit Rilski”, Blagoevgrad, Bulgaria

\section{Deputy Chief Editor}

Vladislav Krastev, SWU “Neofit Rilski”, Blagoevgrad, Bulgaria

\section{Editorial Board}

\section{Paul Leonard Gallina,}

Williams School of Business, Bishop's University Sherbrooke, Québec, Canada

José António Conceição Santos,

The School of Management, Hospitality and Tourism of the University of Algarve, Portugal

Preslav Dimitrov,

SWU “Neofit Rilski”, Blagoevgrad, Bulgaria

Dimitar Dimitrov,

SWU “Neofit Rilski”, Blagoevgrad, Bulgaria

Nikolay Marin,

SWU "Neofit Rilski”, Blagoevgrad, Bulgaria

\section{Yuliana Mateeva,}

Varna Free University, Bulgaria

\section{Andriyana Andreeva,}

University of Economics - Varna, Bulgaria

\section{Stanka Tonkova,}

University of National and World Economy, Bulgaria

Gancho Ganchev,

SWU “Neofit Rilski”, Blagoevgrad, Bulgaria

\section{Almaz Kadyraliev,}

Musa Ruskulbekov Kyrgyz Economic University

\section{Bakas Bakhtiyar uulu,}

Musa Ruskulbekov Kyrgyz Economic University

\section{Tran Van Hoa,}

Hue University, Vietnam

Truong Tan Quan,

Hue University, Vietnam

\section{Pham Xuan Hung,}

Hue University, Vietnam

Farhad Sariev,

K. Tynystanov Issyk-Kul State University, Kyrgyzstan 


\section{Maksat Erkimbaev,}

K. Tynystanov Issyk-Kul State University, Kyrgyzstan

\section{Svetlana Sirmbard,}

Adam University, Kyrgyzstan

Abdyrakhman Subankulovich Mavlyanov,

Adam University, Kyrgyzstan

Almakuchukov Keneshbek Mukashevich,

Adam University, Kyrgyzstan

\section{Dimitris Aidonis,}

Technological Educational Institute of Central Macedonia at Serres

Dimitris Folinas,

Technological Educational Institute of Central Macedonia at Serres

\section{Doaa Salman,}

October University for Modern Sciences and Arts, Cairo, Egypt

Petar Parvanov,

SWU “Neofit Rilski”, Blagoevgrad, Bulgaria

\section{Katarina Valaskova,}

University of Zilina, Slovakia

\section{Pavol Durana,}

University of Zilina, Slovakia

Bistra Vasileva,

University of Economics - Varna, Bulgaria

Desislava Serafimova,

University of Economics - Varna, Bulgaria

\section{Hristina Blagoycheva,}

University of Economics - Varna, Bulgaria

\section{$\underline{\text { Production Editors }}$}

Blagovesta Koyundzhiyska-Davidkova,

SWU “Neofit Rilski”, Blagoevgrad, Bulgaria

Ivanka Vasenska,

SWU “Neofit Rilski”, Blagoevgrad, Bulgaria

Vesela Mircheva,

SWU “Neofit Rilski”, Blagoevgrad, Bulgaria 


\section{CONTENT}

PROTECTING THE RIGHTS OF CRIME VICTIMS FOR THE SAKE OF PEOPLE BROUGHT TO CRIMINAL LIABILITY... p. 1-8

Stefcho Bankov

ENVIRONMENTAL PROBLEMS IN NIGERIA: POLLUTION IN FOCUS p. 9-19 Kehinde Adeola Olufunke

PROSPECTS OF INVESTMENT IN DIGITAL ART: CASE OF ETHEREUM AND NONFUNGIBLE TOKEN (NFT) .p. 20-30

Doaa Salman Abdou

Fatma Abou Elnasr

IDEALIZATION OF ESTABLISHING THE PROFESSIONAL DATA PROTECTION OFFICER FOR FINANCIAL TRANSACTION MANAGEMENT IN INDONESIA:

REFLECTING ON EUROPEAN UNION p. 31-42

Carissa Christybella Wijaya

Fajar Sugianto

Rizky P.P. Karo Karo

Tomy Michael

EFFECTIVNESS OF WORK MOTIVATION AND ITS INFLUENCE ON WORK OUTCOMES.

Philip R. Ivanov

Mariana N. Usheva

CAPITAL FLOWS AND ECONOMIC GROWTH. EVIDENCE FROM

VIETNAM.

Yen Hai Nguyen

Pham Xuan Hung

LEGAL PROTECTION FOR DEATH PENALTY CONVICTS WHO ARE NOT

EXECUTED IMMEDIATELY AFTER THE PERMANENT LEGAL FORCE.......p. 72-84 Abdul Azis Muhammad

Prija Djatmika

Dhiana Puspitawati

Nurini Aprilianda

DISCIPLINARY RESPONSIBILITY OF HABILITATED PERSONS FOR VIOLATION OF LABOR DISCIPLINE UNDER BULGARIAN LEGISLATION. p. 85-97 Andriyana Andreeva

ACTIVE POLICIES IN THE EUROPEAN LABOR MARKET DURING THE COVID-19 PANDEMIC. p. 98-110 


\title{
PROTECTING THE RIGHTS OF CRIME VICTIMS FOR THE SAKE OF PEOPLE BROUGHT TO CRIMINAL LIABILITY
}

\section{STEFCHO BANKOV ${ }^{1}$}

\begin{abstract}
The article raises issues related to the lack of effective mechanisms for protection of the rights of victims of crime under the Bulgarian Penal Code. The author discusses the shortcomings in the criminal proceedings and how the application of the norms for protection of the accused's consignment in the commission of the crime, in fact, limits the right to defense of the victim. An overview of the existing regulation of the problem in the European legal system has been made. Finally, the author examines the contradictory case law and how it in itself restricts the victim's right to a fair trial.
\end{abstract}

Keywords: criminal law, European legal system, victim, accused, court trial

JEL Codes: $K 42$

\section{Introduction}

The insufficient guarantee for protecting the rights of crime victims /victims of crime/ from the people, brought to criminal liability, is one of the current outstanding questions for the criminal justice in the Republic of Bulgaria. Its disputed character and the complicity of these matters are due to the necessity to find the balance between protecting the rights of those, brought to criminal liability and those that are victims of the crime. It can be noted that there is an increasing tendance to change the paradigm of criminal proceedings aimed at focusing more on the rights of the victims and of those harmed by the crime.

According to the Interpretative Decision of the SCC № 1 / 04.02.2013. it is established that there is contradictory case law on the application of the legal provisions related to the fate of the civil claim, duly accepted for joint consideration in the criminal proceedings, upon occurrence of any of the grounds for repayment of the criminal prosecution, specified in Art. 79, para. 1 of the Penal Code. The Decision states that the latter Art. is reduced to two main statements: first, the court must rule on the civil claim, regardless of the grounds for repayment of the criminal prosecution against the defendant and second - after the termination of criminal proceedings due to any of these grounds, the court can not deals with the accepted civil claim.

The issue of considering the civil claim in criminal proceedings, when the grounds for repayment of the prosecution - expired statute of limitations, subsequent amnesty or death of the perpetrator, must be clarified in accordance with established in theory and practice the principles of the legal nature of civil claims in criminal proceedings, in compliance with the new rules for the status of the victim 3 of a crime, introduced by the Criminal Procedure Code / prom. SG, no. 86 / 28.10.2005, in force since 29.04.2006 / and respect for the international acts and the decisions of the European Court of Human Rights / ECHR /, related to their implementation.

For the first time in the new PPC / prom. SG, no. 86 / 28.10.2005, in force from 29.04.2006 / the person who has the capacity of a victim of the crime is brought out as a separate

\footnotetext{
${ }^{1}$ Ph.D., South-West University „Neofit Rilski“, Blagoevgrad, Bulgaria, smbankov14@gmail.com ORCID iDhttps://orcid.org/0000-0002-8327-2874
}

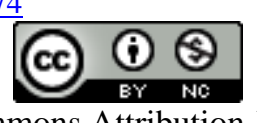

This work is licensed under a Creative Commons Attribution-Non Commercial 4.0 International License. 
figure in the pre-trial phase of the criminal proceedings, in view of the systematic place of Chapter Eight, Section I of PPC in Part One „General Rules“ of the Procedural Code, containing the regulations of all other subjects in criminal proceedings.

Its status is also exhaustively regulated. Upon an explicit request of the victim to participate in the investigation, he/she shall use the provisions of Art. 75 of the PPC rights - to be informed about his/her rights in the criminal process, to receive protection for his/her security and that of his/her relatives, to be informed about the course of the criminal proceedings and to participate in it according to the PPC, to make requests, remarks and objections, to appeal against the acts leading to the termination or suspension of the criminal proceedings, to have a trustee.

It is a noticeable tendency in the criminal process the change of the new paradigm and its objective to focus on the rights of the victims of the crime. For a long time now the rights of the crime victims and their effective legal defence has been a keen topic of interest for the criminal law and theory and practice of criminal proceedings. According to the Criminal Procedure Law currently in force the role of the defendant holds a central place in the criminal proceedings and the defendant has a set of certain rights - relatively better secured by the corresponding procedural guarantees than those of the crime victims. In this respect we need to emphasize that the issue - of the victims of crime is the focus point of attention for the European Union institutions and occupies a leading role in the its work plans. It's not a coincidence that this issue is settled by way of the institutional triangle - European commission - European parliament - Council of the European Union in accordance with their competences laid down in Art. 288 from the Treaty of the European Union².

Relationships between people are built on their personality and behaviour, moral and law and are based on their human desires and strives. In most cases desires and strives are connected to generally accepted values but also tend to vary with the changes in the routine of everybody's life that occur in the way of development. On the other hand today's society is facing one very dynamic social and economic situation, which causes the origin of many contact points between people. Based on this the relationships that get formed are complicated, multi-layered, interconnected, and are regulated by many and different legal divisions. One of the most delicate and problematic spheres to regulate is the one with criminal law relations. In theory it is unambiguously accepted that criminal law relations occur on the occasion of criminal act and its subjects are the state and its institutions that have the power to act in order to impact the legal status of the criminal on one hand and the crime victim on the other hand.

Criminal law relations are regulated by the norms of the criminal law, whose system of norms is committed to protecting the society by regulating the behaviour of the subjects of social relations. The latter regulation is connected to imposing sanction consequences when committing socially dangerous crimes enlisted in the laws, which are declared as crimes according to the criminal codes that are currently in force. Criminal responsibility incorporates three basic authorities of the state and these are: to judge the criminal, to execute the sentence and to treat him/her according to the sentence. The content of the last authority incorporates two interconnected elements - on the one hand, lawful restriction of the rights and on the other hand, the negative public assessment which results in registering the sentence in the criminal

\footnotetext{
${ }^{2}$ Art. 288 Treaty of the European Union: To exercise the Union's competences, the institutions shall adopt regulations, directives, decisions, recommendations and opinions. A regulation shall have general application. It shall be binding in its entirety and directly applicable in all Member States. 26.10.2012 Official EN Journal of the European Union C 326/171 A directive shall be binding, as to the result to be achieved, upon each Member State to which it is addressed, but shall leave to the national authorities the choice of form and methods. A decision shall be binding in its entirety. A decision which specifies those to whom it is addressed shall be binding only on them.

Recommendations and opinions shall have no binding force.
} 
record certificate. And because people are seldom completely isolated in the society as we form and maintain relationships with family, friends and colleagues the criminal liability enforced in its full spectrum is never by itself. It comes and affects not only his/her attitude towards the relationships in the society but also the society itself with the circle of relations of the convicted.

The criminal liability enforced upon the perpetrator is initiated because of the crime he/she accomplished and is not on its own and some kind of "vendetta" towards him. On the other hand the rights of the perpetrator of the crime are well guaranteed during all stages of the trial. This is valid even in the pre-trial phase when the perpetrator becomes defendant and much more during the trial when he/she becomes a party to the legal trial and takes part in it within the conditions of adversarial proceedings. The practice of the European Court of Human Rights in Strasbourg has accepted in multiple cases that the rights of the perpetrator do not originate solely upon his/her formal introduction as defendant to the trial, but can also begin at a much earlier stage. According to the court a person shall be considered a defendant at the beginning of the investigation towards him/her - for instance personal search, criminal examination (check-up) and others of the kind. From this moment onwards the defendant shall have legal rights to defend his/her rights and lawful interests. In the current version of the actual Bulgarian Criminal Law Proceedings and together with the imposed by the European Court of Human Rights practice the figure of the defendant is created - the person brought to prosecution (be it respondent or defendant depending on the different stages of the trial), who has plenty of legal instruments to actively organize his/her legal defence. As a result of all this and based on the huge possibilities to defend the person brought to justice the crime victims have not enough legal instruments to defend their rights and lawful interests and this leads to contradiction with some basic principles, one of which is the rule of law principle stemming from the Constitution of Republic of Bulgaria, the principal of protection against criminal violation of one's rights, the rights of the citizens, the established state legal order, proclaimed in the Criminal Law, the principle of equality of citizen in the criminal proceedings within the framework of adversarial proceedings and equal rights of the parties and last but not least - the principle of cae adjudication within a reasonable timeframe. In this way a recognisable balance is created in the legal opportunities for defending the rights of the defendants on the one hand and the rights of victims of crimes on the other hand. In my opinion and without claiming to be exhaustive on the subject some of the most evident differences that lead to misbalance in the options for protecting the rights of both defendants and crime victims are some of the listed below:

We shall start firstly with the excessive formalization of the legal prerequisites for securing the possibility of thorough and effective protection of the respondent upon his/her choice during the pre-trial phase and of the defendant during the court proceedings. This leads to substantial delays in the court proceedings, in securing the timely defence of the crime victims and even when the rights of the crime victims are protected in many cases it comes too late and because of this delay it is ineffective. In the first place this is due to the option allowed by the law to delay different acts during the pre-trail and the actual trial. The option for the respondent and respectively the defendant to change his advocate in the trial and pre-trial is practically unlimited. In many of the criminal proceedings the defendant speculatively uses his/her lawful right to change the advocate in order to delay certain acts like - appearing in front of the court as a defendant and following this - for interrogation, reviewing materials of the case, taking part in the investigation in those areas where he/she is allowed. The stage of the criminal proceedings is not in any way different - on the contrary - the situation is nearly identical. By using the well-known to all practicing lawyers phrase ,insurmountable differences regarding the line of defence" the laws allow repetitive changes of advocates by cancelling one and delegating authority to a new one in which case the new one in most cases requests a delay in the trial in order to familiarize himself/herself with the materials on the case 
and better organize the defence of the defendant. It is true that criminal proceedings are inter partes and their timely termination within a reasonable timefame should not be affecting the options of the defendant and the crime victim for receiving the adequate defence. However, the latest regulations in the Code of Criminal Procedure give lawful opportunity for the defendant/respondent to manage the trial in the most favourable direction by delaying it considerably and thus preventing the crime victim to get his/her rights and lawful interest protected. To illustrate the above listed statements here are the provisions of Art. 247, par. 1, item 3, where the defendant's participation in the dispositional meeting is appointed as obligatory and his/her failure to attend, no matter the reason, leads to the cancellation of the meeting and rescheduling for another date. Such an option to postpone a court meeting is also provided by provision in paragraph 3, Art. 287 from Code of Criminal Procedure where it is stated that in case of a change in the prosecution, the court shall postpone the court meeting in case the parties need to prepare for the new prosecution. Another well-known situation to all working lawyers is that when a court meeting needs to be rescheduled because the advocate has to participate in another court meeting at the same time. This is another option given by the Bulgarian Code of Criminal Procedure to postpone a court meeting, taking into consideration only the rights of the defendant, but not those of the victim of the crime. A further exemplary situation is in the pre-trial phase when the case gets delayed because even if not so often the advocate of the defendant has to reschedule the court meeting because of other appointments at the same time, but at another location.

Another example is returning the cases from appellate or cassation to lower instances instances which also delays the criminal proceedings and as a result less attention is paid to protecting the rights and lawful interests of the crime victims. The focus in this case rather than being on the victim of the crime is on eliminating the violations in the criminal process that lead to limiting the possibilities of defending the rights of the defendant, which in many cases is an absolute formality and does not exist in reality. However, because of the existing formalism in criminal proceedings this situation cannot be avoided in the trial despite the court's commitment for timely closing of the criminal proceedings.

It is worth mentioning that any delay that occurs in the criminal proceedings is always affecting in a bad way the defence of the crime victims' rights and even more - in most cases it not only cause detriment to the defence of the crime victim, but is definitely an advantage for the defendant. There are many cases known in practice when because of witnesses' death and lack of remembrance of important facts by other witnesses the case is closed by acquittal simply because a conviction cannot be grounded on assumptions while for reaching acquittal it is enough to spread suspicion in the indictment of the prosecutor. The latter is easy to achieve when there is a case of death among the witnesses or when important facts cannot be clarified with sufficient certainty by other witnesses. Because of this and as a conclusion I think it is right to say that any delay in the crime proceedings no matter if it favours the culprit (or the defendant in that respect) is always detrimental for the victim of the crime. It is one of the factors that contributes to the misbalance in the possibilities to protect the rights of the crime victims and opens the door for the culprit or defendant to the unlimited possibility to protect himself/herself, who in many cases will deceitfully take the chance to use it.

The next issue in line to be mentioned is that according to Art. 124 from Bulgarian Code of Criminal Procedure, the prosecution and the sentence cannot be based solely on the testimony of the witnesses, given by the regulation of Art. 141 or 141a, namely interrogation of a witness with secret identity (which proves to be one of the ways to secure the protection of the witness, who in many cases is also one of the victims of the crime) and also of an undercover officer. This regulation includes the idealistic legislative idea that the person considered to be the respondent has to have the option to defend his/her rights and lawful 
interests and at the same time be protected against „the Inquisitorial” crime proceedings based solely on the testimony of witness with secret identity or testimony of an undercover officer. Despite the good legislative intention a legislative regulation is created that additionally increases the misbalance in proceedings providing more options to predominantly protect the respondent and much less the victim of crimes. Not only this but the regulation also detriments the rights of the crime victims in two different aspects. First of all it is impossible to keep the identity of the crime victim secret and this by itself infringes on his constitutional right to have his/her rights and legitimate interests protected as well as the right to participate in the criminal proceedings, which must be conducted in the conditions of adversarial proceedings. This also contradicts the constitutional principle of the rule of law and contributes to the ineffective protection of the victim of crime, who, if afraid and feeling threatened, cannot keep his/her identity a secret. This also contributes to the fact that some of the committed crimes are classified as latent, undeclared criminal activity. Second of all this provision also undermines the ability of the victims of the crime to be protected by the means, given by the criminal proceedings which could lead to a conviction of the perpetrator of the crime, whose sentence would fully protect the rights of victims of crime. This limits the ability of victims of crime to participate equally and adversarially in criminal proceedings, as in practice their testimony cannot be the only evidence against the person prosecuted, as the accusation and the sentence cannot be based on them alone.

The infringement of the adversarial principle of criminal proceedings, based on the above provision is the second aspect which outlines the violation of the right to protection of victims of crime and the creation of a privileged position to protect the rights of the person who has been prosecuted.

It is well known to all citizens that the Constitution of the Republic of Bulgaria does not allow any restrictions of the rights or privileges, based on race, nationality, ethnicity, sex, origin, religion, education, beliefs, political affiliation, personal and social status or property status. (according to Art. 6 of the Constitution of the Republic of Bulgaria). On the other hand, in the specific case with the provision of Art. 124 of the Code of Criminal Procedure a privileged position of the person brought to criminal responsibility at the expense of the victims of crimes is allowed and leads to the restriction of the right to protection of the latter. A privilege is created on the basis of acquiring the procedural capacity of "respondent" for the pre-trial proceedings, respectively a "defendant" in the court phase. Another provision of the current Bulgarian Criminal Procedure Code, which leads to a restriction of the possibilities for protection of the rights of the victims of crimes, giving precedence in ensuring the protection of the rights of persons brought to criminal justice is that of Art. 281, para. 3. According to it under the conditions of Art.. 281, pp. $1-6$ of the Code of Criminal Procedure the testimony of a witness given before the bodies of the pre-trial proceedings may be read only when and if the accused and his defence counsel have been present in the interrogation when the testimony was given. It is clear that the legislative idea was to ensure the possibility for the accused and his defence counsel to participate in the criminal proceedings in a direct manner, such as their direct participation in the interrogation of a witness. However, this provision in no way contributes to the protection of the rights and legitimate interests of victims of crime. This provision is, to put it mildly, discriminatory against the victims and even against the pre-trial authorities leading to the evidence collected by them being practically worthless when the person prosecuted and his/her defence counsel have not participated in the interrogation. In this case, the legislator has chosen to helpfully credit with more trust the person prosecuted and his defence counsel instead of the civil servants conducting investigations and ensuring their comprehensiveness, objectivity and completeness, as well as the disclosure of the objective truth. The legislator openly shows to the public his distrust and prejudice against the pre-trial 
authorities, which not only reflects publicly on the trust granted to the latter, but also ruins the opportunities for protection of victims of crime while at the same time provides a limitless and biased opportunity to ensure the protection of the persons being prosecuted.

To this already established imbalance also contributes pp. 4 of Art. 281, which in turn further restricts the ability to read witness statements, given in front of the pre-trial authorities when the person prosecuted and his defence counsel have not been present, only up to the cases of Art. 281, para 1, items 1-2 of the Code of Criminal Procedure. Here again, all the arguments listed in the previous paragraph can be repeated one more time.

The last procedural norm, which contributes to the already existing imbalance in the possibilities for legal protection of the rights of victims of crime, regarding the interpretation of the interrogation of witnesses, is the provision of para. 8 of Art. 281, in which it is stated that the conviction cannot be based only on amtestimony read under para. 4 of the same article. As can be stated again, this constitutes a legislative ,devaluation" of the evidence, collected in the course of the pre - trial proceedings by its authorities (most often the investigating police officers or investigators) at the expense of ensuring the apparent adversarial nature of the criminal proceedings during which the main role occupies the court phase. Indisputably however the meaning of the current Criminal Procedure Code is to provide an opportunity to protect the citizens of the Republic of Bulgaria, including victims of crime, and rather not only those brought to justice whilst demonstrating an obvious disinterest in the possibilities of protecting the rights of victims of crime.

It is good to know that regarding the imbalance in the possibilities for protection of the rights of the victims of crimes and the persons brought to criminal justice the provision of Art. 371, item 1 of Criminal Procedure Code is also valid. According to this provision ,at the preliminary hearing of the parties the defendant and his defence counsel, the civil plaintiff, the private prosecutor and their trustees may agree not to question all or some witnesses and experts, and when announcing the sentence to directly use the content of the relevant protocols and expert opinions from the pre-trial proceedings". At first sight, that provision in no way affects the possibilities for protecting the rights of victims of crime. But all lawyers actively working in the system are well aware that it is possible in a shortened court investigation under Art. 371 item 1 of the Criminal Procedure Code to reach an acquittal. In this sense, if the prosecutor did not observe the pre-trial proceedings strictly enough and because of this the same has „omissions or weaknesses“ it is quite possible when requesting an abbreviated court investigation under item 1 of Art. 371 of the Criminal Procedure Code to reach an acquittal. This occurs whether or not the „omissions or weaknesses in question“ were found by the civil plaintiff and the private prosecutor and their trustees and whether or not they did not disagree with the conduct of an abbreviated court investigation, because their opinion in connection with the defendant's initiative to conduct the abbreviated cour investigation is not binding on the court. This principle is adopted in Interpretative Decision № 1/2009 under Interpretative Case 1/2008 from General Meeting of the Criminal Colleges of Supreme Court of Cassation. This is another example of a norm of the current Criminal Procedure Code, in which the defendant was given a legal opportunity to organize the line of defence in his/her own interest, which possibility he may exercise independently and without consent, and even with the unambiguous disagreement of victims of crime, who in this case may have the procedural capacity of a private prosecutor or a civil plaintiff. This norm again undermines the possibilities for protection of the rights of victims of crime and shows the real imbalance and excessive "legislative concern" towards persons brought to criminal justice.

And last but not least we should mention the contradictory practice of the courts. There is a certain group among the judges in the Republic of Bulgaria who accept that upon filing an indictment and initiating court proceedings an agreement may be concluded between the 
prosecution and the defendant and his defence counsel for a crime that is less punishable and/or not qualified, provided that the indictment indicates a more seriously punishable or qualified constitution of the same crime. There are other judges who believe that the proposed agreement contradicts the law and therefore should not be approved.

We can definitely say that the first opinion is more correct. The main argument in support of the above is that that as soon as the court can find the defendant guilty of a less punishable offense of the same crime, by acquitting him/her for the more seriously punished crime, this does not prevent it from approving the agreement thus reached. But despite the formal protection and safeguarding of the rights of the defendant, I believe that such an interpretation and application of the law is incorrect and even contradicts the law itself. But the worse consequence of this misinterpretation is that it is again focused only on the possibilities for procedural protection of the rights of the persons brought to criminal justice and the court totally neglects the protection of the rights of victims of crime. Notwithstanding the subsequent possibility of the defendant being convicted by another court panel this inevitably leads to at least a delay in the criminal proceedings and the enactment of a final judicial act, which would have generated legal action and created a sense of security, justice and even retribution for victims of crime.

In this regard and without claiming to be exhaustive, the author considers that some of the norms of the current Code of Criminal Procedure that have been listed above protect better the rights of the persons brought to criminal justice showing criminal indifference to the protection of the rights of victims of crime. Moreover, these norms are to the detriment of the legal possibilities for protecting the rights of victims of crime. Generally speaking, some of basic principles proclaimed in the National Republic of Bulgaria have been violated, namely that of the rule of law, the right to the protection of the rights and legitimate interests of citizens, their equality and the adversarial nature of the criminal process, giving priority to the protection of the rights of persons brought to criminal responsibility at the expense of the victims of crime. The democratic society in Bulgaria, being part of the European Union, should take its responsibility and take the necessary urgent and immediate measures, by making the necessary legislative amendments and provide equal opportunities for the protection of victims of crime with those of the persons brought to prosecution. Otherwise, there is a serious danger that the existing imbalance would lead to a serious debilitation of the democratic foundations in Bulgarian society and to demeaning and neglecting the constitutionally proclaimed principle of the rule of law. 


\section{References}

Stoynov, A. (2017). Criminal law - in general (first edition). Ciela Publishing House.

\section{Law and Regulation}

Criminal Code of the Republic of Bulgaria

Criminal Procedure Code of the Republic of Bulgaria. (PPC / prom. SG, no. 86/28.10.2005, in force since 29.04.2006).

Interpretative Decision № 1/2009 under Interpretative Case 1/2008 from General Meeting of the Criminal Colleges of Bulgarian Supreme Court of Cassation.

Law of protection of persons threatened in connection with criminal procedure. (2004). Retrieved from http://www.legaltheory-forums.org 


\title{
ENVIRONMENTAL PROBLEMS IN NIGERIA: POLLUTION IN FOCUS
}

\section{KEHINDE ADEOLA OLUFUNKE ${ }^{1}$}

\begin{abstract}
Environmental problem in Nigeria is a phenomenon that needs urgent attention from the relevant stakeholders and concerned individuals. Environmental problem in Nigeria comes in diverse ways and forms and they lead to various forms of hazards both on the citizens and the environment at large. It has been discovered that the laws put in place for regulating the environment is grossly inadequate and thus, there is a need to amend some of these laws and ensure adequate enforcement of the ones already enacted as it has been identified that there is a lack of enforcement mechanism by the bodies saddled with the responsibility of enforcing these laws already put in place. This paper examined some of the environmental problems in Nigeria and focuses mainly on pollution as a significant problem affecting the Nigeria environment. Various forms of pollution were identified, causes and effects of pollution were adequately addressed in this paper. The paper was not concluded without proffering solutions to the identified problems.
\end{abstract}

Keywords: Environment, Pollution, Environmental problem, Environmental Law, Nigeria

JEL Codes: K32, K38

\section{Introduction}

Generally speaking, whenever there is a new environmental problem in any part of the world, it becomes a global issue and international conference will be held in that regard to address the issue and a new treaty is negotiated: and such include depletion of the stratospheric ozone layer (United Nations, 1985), transboundry movements of hazardous wastes (United Nations, 1989), climate change (United Nations, 1992a), the loss of biological diversity (United Nations, 1992b), desertification (United Nations, 1994), pollution and so on. Environmental problems generally occur as a result of activities of human beings in the environment. People abuse the environment through their acts of disobedience to the laws enacted relating to the protection of the environment and their own selfish interest without putting other habitats of the environment into adequate consideration. It must be pointed out that the laws relating to the environment is of little importance unless accompanied by effective means for ensuring the recognition, application/enforcement, compliance and the settlement of disputes arising therefrom. In other words, those laws are as toothless dogs unless and until they are enforced. Thus, violation and non-compliance with these laws will definitely lead to environmental problems. This article will focus mainly on pollution as an environmental problem in Nigeria.

\section{Methodology}

The article relies on the doctrinal research methodology. Doctrinal research is concerned with legal propositions, the sources of data are legal and appellate courts decisions. It is library research; it includes primary and secondary sources. The primary sources are Statutes, Constitution, Acts and Laws while secondary sources are books, articles etc.

\section{${ }^{1}$ Faculty of Law, Federal University Oye Ekiti, Ekiti State, Nigeria, olufunke.kehinde@ @uoye.edu.ng ORCID iDhttps://orcid.org/0000-0002-1554-6247}

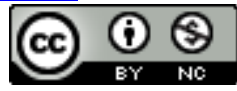

This work is licensed under a Creative Commons Attribution-Non Commercial 4.0 International License. 
Some of the primary sources explored here are: The 1999 Constitution of the Federal Republic of Nigeria (as amended), National Environmental Standard Regulatory and Enforcement Agency Act (NESREA Act), Petroleum Regulation, Environmental Impact Assessment Act (EIA Act), Land Use Act among others. The secondary sources include books, articles and journals related to the subject matter of this research. The internet has turned the whole world not only into a global village but also a global room. It helps a lot in various researches of various natures. There is no information needed that cannot be obtained from the internet. Thus, the internet is of tremendous help in putting this article together.

\section{Definition of terms}

\section{Environment}

Environment was defined ${ }^{2}$ as consisting of all or any of the following media, namely the air, water and land; and the medium of air includes the air within buildings and the air within other natural or manmade structures above or below ground. This has been repealed by the Pollution Prevention Act 1999 which retains the same definition in the context of environmental pollution. Elements of the environment has also been described as including air and atmosphere, water, soil, land, landscape and natural sites including wetlands, coastal and marine areas, biological diversity and its components including genetically modified organisms, and the interaction among these elements (Osborn et al., 2013, p. 165). Environment is a very difficult word to define. Its normal meaning relates to the surroundings but obviously that is a concept which is relatable to whatever object it is which is surrounded. ${ }^{3}$ Environment has also been viewed as a complex relationship existing between the ecosystem and its inhabitants. Scientific explanation contends that environment is the product of a complex ecological system in which human beings and other living and non-living organisms co-exist.

In this context, environment is characterized and classified into two broad categories: physical and cultural. The physical environment is the natural environment, which consists of biosphere, atmosphere, hydrosphere, and lithosphere and their inherent resources. The cultural environment generally encompasses the way of life of a set of people in a specific location including human settlements, cultural, historical and religious aspects of human activities (Amokaye, 2004, p. 4). The environment includes the ways in which the environmental media interact with one another and the ways in which they interact with the man-made environment, the fauna and flora which inhabit them. ${ }^{4}$ It is the total sum of all the external conditions affecting the life, development and survival of an organism (Olawuyi, 2015, p. 6). The environment has also been described to consist of all, or any of the following media, namely the air, water and land, and the medium of air includes the air within buildings and the air within other natural or man -made structures above or below the ground. ${ }^{5}$ It has been defined to include all aspects of the surroundings of man whether affecting him as an individual or in his social and aesthetic factors of those surroundings. ${ }^{6}$

The term environment has also been defined to include Water, Air, Land, and all plants and human beings or animals living therein and the interaction which exist among any or all of them ${ }^{7}$. From whatever perspective the environment is defined, it is our source of sustenance that we depend upon. We depend on it for food, fuel, medicines and other materials needed.

\footnotetext{
${ }^{2}$ Environmental Protection Act 1990 S1(2)

${ }^{3}$ Encyclopedia Law Dictionary (3 ${ }^{\text {rd }}$ ed.)(2008). Nathan and company Law publishers new delhi

${ }^{4}$ ibid

${ }^{5}$ Section 1 British Environmental Act, 1990

${ }^{6}$ Section 20 Water Resources Act 1993 (Nigeria)

${ }^{7}$ Section 38, Federal Environmental Protection Agency Act Cap F 10 LFN 2004
} 


\section{Environmental Law}

Environmental law can be described as a body of rules and regulations, and orders and statutes concerned with the maintenance and protection of the natural environment of a country. It provides basis for measuring and apportioning liability in cases of environmental crime and the failure to comply with its provisions.

Environmental protection proceeded from the moral and ethical belief that those things we all share such the air, water, and land should be protected by all of us who share them; environmental law is the transformation of those moral principles into norms that can be legally enforced (Amokaye, 2004, p. 3). Environmental Law is a body of rules and regulations, orders and statutes that are concerned with the maintenance and protection of the natural environment of a country. It provides basis for measuring and apportioning liability in cases of environmental crime and the failure to comply with its provisions (www.businessdictionary.com). It has also been defined as the branch of law which provides the legal framework for the regulation and protection of elements of the environment such as air, land, water to mention but a few (Olawuyi, 2015, p. 14). It includes the body of laws rules, regulations and statutes that regulate the interactions between humans and the natural environment with the aim of reducing the impacts of man's activity on the environment. ${ }^{8}$

In another view, it represents the body of rules both from the national and international perspectives, for the sustainable utilization of resources for the social and economic development of the society (Amokaye, 2004, pp. 5-6). It is the law that governs the control of the effects of human activities on the physical environment in the overall interest of the public. It embraces the subject matter of several important international agreements and municipal laws, regulations, standards and institutional framework for the equitable and sustainability of the natural deposits. ${ }^{9}$ The primary consideration of laws governing the environment is the provision of the legal platform upon which the environment could be protected and natural resources conserved through the sustainable use of natural resources, pollution control measures, and the integration of environment considerations into developmental process. ${ }^{10}$ There are a lot of international, federal and state environmental statutes that make up environmental law and all these will be discussed in this paper; they are targeted at bringing to the minimal level the hazards associated to the environment and ensure an increase in the level at which the public is enlightened with respect to their health.

Despite the fact that environmental law has made significant progress in ensuring environmental protection in ensuring that some dangers are averted in the environment, there is still need for improvement since the eco-system is still threatened on daily basis as a result of human activities (http/www.cleanwaterpartners.org).

Considering the state of environment today in Nigeria, a lot has changed with respect to the weather we experience: excessive heat, hotter than the one we have years back, harmattan is no longer experienced at the usual time, the same thing happens to raining season, deforestation, loss of natural resources, loss of biodiversity, improper waste management, energy crisis, destruction of habitat as well as pollution levels are some of the emerging environmental crises that is experienced on daily basis. Some laws have been put in place in Nigeria to regulate the use of the environment, these laws will be highlighted one after the other.

\section{Some Laws Regulating Environmental Protection In Nigeria}

\section{Environmental Impact Assessment (EIA) Act ${ }^{11}$ :}

\footnotetext{
8 ibid

${ }^{9}$ ibid

10 ibid

${ }^{11}$ Environmental Protection Act, Cap E12, LFN 2004
} 
This was promulgated to assess the impact of any kind of project on the environment and it further makes it mandatory for an EIA report to be issued from the Federal Ministry of Environment. Environmental Impact Assessment is the process of identification of any contrary effect that may arise from siting certain projects in a particular area as well as the mechanisms put in place to contain, curtail, mitigate such contrary effect and as well ensure that parties who are adversely affected get restitution (William, 2009). Thus, the Environmental Impact Assessment should ensure that before an approval is granted in respect of any project, the appropriate government authorities have fully identified and considered the environmental effects of the activities to be carried out under their jurisdiction and control and affected citizens had an opportunity to understand the proposed project and expressed their views to the decision makers.

\section{The National Environmental Standards and Regulations Enforcement Agency (NESREA) Act ${ }^{12}$ :}

This Act was established in the year 2007. NESREA ${ }^{13}$ as a body replaced FEPA ${ }^{14}$. NESREA was established as a parastatal of the Federal Ministry of Environment, Housing and Urban Development ${ }^{15}$. It is charged with the responsibility for the protection and development of the environment, biodiversity conservation and suitable development in Nigeria's natural resources in general ${ }^{16}$. The vision of the Agency is to ensure that Nigerians have access to a cleaner and healthier environment while the mission is to inspire personal and collective responsibility in building an environmentally conscious society for the achievement of sustainable development in Nigeria (Ariyoosu, 2014).

The Agency's powers are so wide. In the area of protecting the environment, the Agency has the power to prohibit processes and the use of equipment or technology that undermine environmental quality ${ }^{17}$. It also has the power to conduct field follow up compliance with set standards and take procedures prescribed by law against any violator ${ }^{18}$. The Agency also reserves the power to establish mobile courts in order to dispense off cases of environmental violations expeditiously ${ }^{19}$. The Agency can conduct public investigations and make proposals to the minister for the review of existing guidelines, regulations and standards on environment ${ }^{20}$. Also, the Agency can establish programmes for setting standards and regulations for the prevention, reduction and elimination of pollution and other forms of environmental degradation in the nation's air, land, oceans, seas and other water bodies and for restoration and enhancement of nation's environment and natural resources ${ }^{21}$.

\section{Criminal Code Act $^{22}$}

The Acts is Nigeria's principal law on criminal matters. This Act deals with prevention of public health hazard and imposition of punishment in the event of its violation. As earlier stated, most of the provisions of these Laws are obeyed by the citizens as there is a lack of

\footnotetext{
${ }^{12}$ National Environmental Standards and Regulations Enforcement Agency Act 2007Cap 301LFN 2010

${ }^{13}$ National Environmental Standards and Regulations Enforcement Agency

${ }^{14}$ Federal Environmental Protection Agency

15 NESREA was established by the National Environmental Standards and Regulations Enforcement Agency (Establishment) Act No 25 of 2007. Its commencement date was $30^{\text {th }}$ July, 2007. By virtue of the provisions of Section 36 of NESREA Act, the FEPA Act had been repealed

${ }^{16}$ See Section 2, NESREA Act

${ }^{17}$ Section 8 (d) NESREA Act

${ }^{18}$ Section 8 (e) NESREA Act

${ }^{19}$ Section 8 (f) NESREA Act

${ }^{20}$ Section $8(\mathrm{k})$ NESREA Act

${ }^{21}$ Section 8 (o) NESREA Act

${ }^{22}$ Criminal Code Act, Cap C38, LFN 2004
} 
enforcement mechanism. Also, the punishments so prescribed are extremely minimal and in consequence of no effect. There are so many provisions of Criminal Code that are not enforced even till date; for instance, Criminal Code makes it an offence for any dead person to be buried within a dwelling house. It is evident in Nigeria today that many people for different reasons which include but not limited to tradition, the love they have for their loved ones still bury their dead ones in their houses and still get away with it. It is pertinent to state here that any Law that lacks enforcement mechanism is ineffective; and that is what we have in Nigeria. A lot of beautiful Laws are in existence but they are not being properly enforced. When a Law is made and same is not enforced, it is as good as saying there is no Law in that regard.

\section{Kanji Lake National Park Act ${ }^{23}$}

This Act provides for the establishment of Kanji Lake Park. It also makes further provision for controlling, managing and maintaining the park as well as ensuring the security of animal and plant life within the park. It has been discovered that this law has been ineffective too as a result of non enforcement of its provisions.

\section{Endangered Species (Control of International Trade and Traffic) $\mathbf{A c t}^{24}$}

This Act provides for the conservation and management of the wildlife of the country and the protection of species in danger of extinction due to over-exploitation.

\section{Petroleum Regulation ${ }^{25}$}

This prohibits the discharge or escape of petroleum into waters within harbor areas and makes provisions for precaution in the conveyance of petroleum and rules for safe operations of pipeline.

\section{Oil in Navigable Waters Act ${ }^{26}$}

By the provisions of this Act, the discharge of oil or any mixture containing oil into the territorial or navigable inland waters is prohibited. The Acts by the provisions ${ }^{27}$ makes it an offence for any Nigerian ship to discharge oil into the prohibited sea areas created under the international convention and contained in the Schedule to the Act. The oils include crude oil, fuel and lubricating oil and heavy diesel oil. ${ }^{28}$

\section{Oil Pipeline Act ${ }^{29}$}

This Acts prohibits the pollution of land or any waters. It provides further that the holder of an oil license shall pay compensation to the victim(s) of oil spillage. ${ }^{30}$ The provisions of the law are grossly abused in Nigeria and this is really disheartening as water is polluted on daily basis as a result of activities of oil industries and operators.

\section{The Land Use Act ${ }^{31}$}

Land ownership structure is relevant for environmental protection, in that the control and ownership of land often dictates the right to important resources such as oil, natural gas,

\footnotetext{
${ }^{23}$ Kanji Lake Park Act, Cap 197, LFN 1990

${ }^{24}$ Endangered Species (Control of International Trade and Traffic) Act Cap E9, LFN 2004

${ }^{25}$ Petroleum Regulations, 1967

${ }^{26}$ Oil in Navigable Waters Act, Cap O6, LFN 2004

${ }^{27}$ Section 1(1) ibid

${ }^{28}$ Section 1(2) (ibid)

${ }^{29}$ Oil Pipeline Act Cap O7, LFN 2004

${ }^{30}$ Section 11 (5) (a-c) ibid

${ }^{31}$ The Land Use Act, Cap L5 LFN2004
} 
mineral resources and agricultural products found on the land. Section 1 of the Act now vests ownership of land within a state in the State Governor who holds the land in trust and administers it for the benefit of all Nigerians. The general aim of the Act was to vest absolute ownership of land in each state in the state governor. The governor allocates such land for commercial, agricultural and other purposes via a grant of statutory right of occupancy or customary right of occupancy.

The Act further provides that such a right given to an individual by the governor may also be revoked by him for overriding public interests. ${ }^{32}$ This includes the requirement of the land for mining purposes or oil pipelines or for any purpose connected therewith. This provision makes it possible for the Nigerian government to appropriate land containing oil and gas. To that effect, government can take over even private or industrial land, wherever oil is found, in the interest of the general public (Olawuyi, 2015, pp. 21-22).

\section{The National Guidelines and Standards for Environmental Pollution Control}

This was launched on March $12^{\text {th }} 1991$ and represents the basic instrument for monitoring and controlling industrial and urban pollution.

\section{The 1999 Constitution of the Federal Republic of Nigeria ${ }^{33}$}

It is worthy of note that the 1999 Constitution of the Federal Republic of Nigeria recognizes the need to protect the environment. The Constitution recognizes the need for environmental protection as it provides that "the state shall protect and improve the environment and safeguard the water, air and land, forest and wild life of Nigeria." It is obvious from this provision that the government realizes that there is a need to protect the environment so as to make it worth living for the Nigerian people.

It is worthy of note that as beautiful as this provision is, it falls within the rights under Chapter II of the Constitution which are non justiciable rights ${ }^{34}$. It is my view that this right should be one of the rights under Chapter IV of the Constitution so as to enable it have the kind of weight it ought to have in the country. As far as this right is concerned, it is just a toothless bull dog. The Constitution as the principal legislation in the country should ensure that this right is justiciable.

This paper move on to consider environmental pollution in Nigeria without leaving behind its impacts or effects on Nigerians, other living organisms and the Nigeria environment at large.

\section{Pollution}

Pollution is what we experience daily in Nigeria, it can be safely concluded that the problem has become part of us as we live with it without any form of concrete intervention from the government and the relevant stakeholders in the industry, thus, people have assumed that it is probably something they have to continue to live with without any option. Pollution generally simply means the introduction of harmful products into the natural environment that can lead to various negative or unfavorable effects.

There are different types or forms of pollution, they include but not limited to: Air pollution, Water pollution, Soil pollution and Noise pollution. These will be discussed one after the other.

\section{Air pollution}

\footnotetext{
${ }^{32}$ Section 28 ibid

${ }^{33}$ The 1999 Constitution of the Federal Republic of Nigeria, Cap C23, LFN 2004

${ }^{34}$ Section 6 (6) (c) of the Constitution of the Federal Republic of Nigeria 1999 (as amended)
} 
This happens whenever there is a release of hazardous substances into the environment. Some air pollutants include nitrogen oxide, sulfur oxide, carbon monoxide and Chlorofluorocarbons. Primary pollutants are referred to as the harmful substances that directly affects the air we breathe in. Examples of such contaminants include carbon monoxide and sulfur dioxide. Likewise, secondary pollutants arise if primary pollutants in the atmosphere undergo chemical reactions, example of this is photochemical smog (Nathanson, 2020).

Air pollution is what we experience daily in Nigeria; due to the electricity challenges Nigeria as a country is facing, people are compelled to make use of alternative source of power supply which include the use of generators. Nigerians use this generator for different purposes which include domestic and commercial purposes. It may be used for a period of 24 hours which amounts to a whole day. The smoke released by the generator definitely pollutes the air which is so harmful to human health.

Furthermore, the machineries used in most industries generate smoke and release gaseous emissions which are also harmful to the public at large. Our mode of refuse disposal in Nigeria is so terrible and disheartening. Refuse are dumped into drainages, close to premises inhabited by human beings, some waste boxes even provided for refuse dumping by the government or organizations are placed so close to places people live in or carry on their businesses: this infact affects the people because inhalation of these refuse leads to one disease or the other which is as a result of polluting the environment. Some even go to the extent of collecting the refuse in a place and later set it ablaze in a location so close to them, some instead of cutting the grasses around them prefer to put fire on it and there is no way the smoke generated from these burning will not be inhaled; this constitutes air pollution.

\section{Water Pollution}

This arises in a situation whereby wastes are released into water which leads to the contamination of such waster and this could be by chemical, physical, radioactive or pathogenic microbial substances (Kehinde, 2019). Water is said to be contaminated when it is affected by various activities whether natural or artificial which makes it impossible for human use and renders it inhabitable for aquatic organisms. ${ }^{35}$

There are several instances when water close to an industry is contaminated from emissions from the industry. It is very essential that Environmental Impact Assessment is carried out before an industry is sited; any company that fails to comply with this regulation should be sanctioned accordingly. Those who suffer a lot in this respect are people living in the Niger Delta area of Nigeria. For instance, three teenagers were reported dead in Lotugbene community in Bayelsa State Nigeria after allegedly drinking water from a river polluted by the rig operation of an oil company in the area. The affected children supposedly died of cholera after vomiting and stooling for a while. The river is the only source of drinking water to the community. The chiefs, elders and youth leaders of the community then handed down a sevendays ultimatum to the company to quit the area. It was said the quality of water in Lotugbene was affected since October 6, 2011 when the oil company started drilling a rig and allegedly polluted the entire river in the process.

\section{Soil Pollution}

Soil pollution is defined as the contamination of the soil by chemicals, salts, radioactive materials, disease causing agents or toxic compounds which have unfavorable effects on plant's growth and animal health. ${ }^{36}$ It happens as a result of man-made activities in the environment which alters the natural soil environment. Thus, it can be rightly said that pollution of soil

\footnotetext{
35 ibid

36 ibid
} 
happens due to the presence of manmade elements which could be through industrial activities, improper waste disposal or chemicals used for agricultural purposes.

Soil Pollution has the following effects:

\section{(1) It affects Human Health}

Contamination of soil has a negative effect on human health. Crops and plants grown on the soil that has been contaminated do absorb much of the pollution and then pass these on to us whenever such crop or plant is taken or consumed by us. It can lead to famine since plants will be unable to grow well on it as a result of the contamination.

\section{(2) It affects plants growth}

As earlier mentioned, once a soil is contaminated, it will be difficult for any plant to thrive on it, thus, making it impossible for the said plants to grow as expected because the chemistry of the soil has been altered. This creates an additional problem of soil erosion.

(3) It leads to reduction of soil fertility

Soil fertility is grossly reduced as result of contamination. The contaminated soil cannot produce healthy fruits and vegetables. The said fruits and vegetables may contain some poisonous substances which can lead to serious health problems for those who consume them.

\section{(4) It changes soil structure}

When soil is polluted, it becomes absolutely impossible for organisms living therein to thrive which eventually lead to their death. The death of these soil organisms (e.g. earthworms) leads to alteration of soil composition (Conserve Energy Future, 2018).

\section{Noise Pollution}

This happens when the noise level crosses the normal decibel level. Sound is essential to our daily lives, but noise is not. Noise is generally referred to as an unwanted sound, or sound which produces unpleasant effects and discomfort on the ears (www.eSchoolToday.com).

Generally speaking, noise is generated from household gadgets, big trucks, vehicles and motorbikes on the road, jet planes and helicopters hovering over cities, loud speakers and son on. All these are experienced on daily basis in Nigeria which is really affecting all living organisms including human beings (Khanna, 2011).

It must however be pointed out that the Federal and State governments across Nigeria have put in several efforts to ensure that safety of the environment is guaranteed by way of promulgation of various laws. It has been observed that most of these laws are ineffective as they are obsolete, penalties prescribed for violations of the laws are ridiculous and serves as no means of deterrence to violators because some prefer to violate the laws and pay the ridiculous fines if even prosecuted atall. It has also been observed that the enforcement mechanism is so weak, most of these laws are not obeyed and violators get away with same as there is no one to enforce the laws. The executive arm of government responsible for enforcement of laws across the country are not rising up to the responsibility and nobody sanctions them for failure on their part to ensure enforcement of the existing laws. In effect, three major issues have been identified in this work: inadequacy of the existing laws, non-compliance with the existing laws and lack of enforcement of the existing laws.

Form the above discussion, the hazards associated with pollution in Nigeria have been identified and discussed, it can be deduced that the level of pollution in the country is on the high side and such needs to be urgently addressed by the Nigerian government and other relevant stakeholders in the environmental sector in order to guarantee environmental safety and protection for Nigerians which will be in line with the provisions of the 1999 Constitution of the Federal Republic of Nigeria (as amended) as discussed above. 


\section{Recommendations and Conclusion}

Pollution in Nigeria has become a daily occurrence and in fact, Nigerians can be said to be accustomed to it because it is what they experience all time. It must however be pointed out here that the mere fact that they are accustomed to it because they do not have a choice does not limit its effect on their health generally. The effect of pollution cannot be underestimated. Nigerians should ensure they avoid the habit of polluting the atmosphere with their negligent acts because most of the pollution as discussed above are manmade. The Nigeria Government should ensure that adequate laws are enacted in addition to the existing ones so as to guarantee environmental protection. The Nigerian Government should also ensure strict compliance with the provisions of the laws already enacted and the ones to be enacted so as to guarantee environmental protection because if these laws are enacted and they are not complied with, they are of no use and the purpose of such enactment is defeated. In addition, there is an urgent need to amend most of the existing laws as mentioned above because some of the provisions are obsolete, penalties prescribed are ridiculous as the world is changing on daily basis; and one of the characteristics of law is its dynamism, as it is not static; thus, laws must be amended to meet up with the current challenges of the country. Also, the enforcement mechanism must as a matter of urgency be strengthened; when people are sanctioned for their actions, this will serve as a form of deterrence to prevent future occurrence of same.

In addition, Nigeria Government should ensure stable provision/supply of electricity. Although the Government has commenced a good work in this regard by privatizing the power sector which was officially done in October 2013, it should ensure that the privatization effort is not frustrated and that its effect is made known and enjoyed by Nigerians, this will minimize the level of pollution generated from the use of generators and so on.

\section{Abbreviation:}

FEPA: Federal Environmental Protection Agency

NESREA: National Environmental Standards and Regulation Enforcement Agency 


\section{References}

Amokaye G. O. (2004). Environmental Law and Practice in Nigeria. University of Lagos Press

Ariyoosu, D. A. (2014). An Examination of legal regulation and environmental impacts of telecommunications installations in Nigeria. Journal of Law, Policy and Globalization, 30, 88-96.

Conserve Energy Future. (2018, January 20). Soil Pollution: Definition, Causes, Effects and Solutions. Retrieved from http://www.conserve-energy-future.com/causes-andeffects-of-soil-pollution.php

eSchoolToday. (2021, January 20). Pollution: What is noise pollution? Learn Something New Today. Retrieved from https://eschooltoday.com/learn/what-is-noise-pollution/

Kehinde, A.O. (2019). Legal Control of improper and effect of improper solid waste management in Nigeria. Novena Law Journal, 6(2).

Khanna, B. (2011, January 3). What are the harmful effects of Noise Pollution. PreserveArticles.Com: Preserving Your Articles for Eternity. Retrieved January 20, 2014, from https://www.preservearticles.com/environment/harmful-effects-of-noisepollution/785

Nathanson, J. A. (2020, October 19). air pollution. Encyclopedia Britannica. Retrieved from https://www.britannica.com/science/air-pollution. Accessed 29 Ocober, 2021

Olawuyi, D. S. (2015). The principles of Nigerian environmental law. Afe Babalola University Press.

Osborn, P. G., Woodley, M., \& Bainbridge, J. (2013). Osborn's Concise Law Dictionary. Sweet \& Maxwell.

United Nations. (1985). Vienna Convention for the Protection of the Ozone Layer. Treaty Series, vol. 1155, p. 331. Retrieved from https://treaties.un.org/pages/ViewDetails.aspx?src=IND\&mtdsg_no=XXVII$\underline{2 \& \text { chapter }=27 \& \text { clang }=\_ \text {en }}$.

United Nations. (1989). Basel Convention on the control of transboundary movements of hazardous wastes and their disposal. 5 May 1992, No. 28911. Retrieved from https://treaties.un.org/pages/ViewDetails.aspx?src=IND\&mtdsg_no=XXVII$\underline{3 \& \text { chapter }=27 \& \text { clang }=\_ \text {en }}$

United Nations. (1992a). UN United Nations Conference On Environment And Development: Framework Convention On on Climate Change. FCCC/INFORMAL/84 GE.05-62220 (E) 2007. 05, May, 1992. Retrieved from https://unfccc.int/resource/docs/convkp/conveng.pdf. Accessed on 01 November, 2021

United Nations. (1992b). Convention on Biological Diversity. Retrieved from https://www.cbd.int/doc/legal/cbd-en.pdf. Accessed on 01 November, 2021 
United Nations. (1994). Convention To Combat Desertification In Those Countries Experiencing Serious Drought And/Or Desertification, Particularly In Africa. Paris, 14 October 1994. Retrieved from https://treaties.un.org/Pages/ViewDetails.aspx?src=TREATY\&mtdsg_no=XXVII$10 \&$ chapter $=27 \&$ clang $=$ en\#1 Accessed on 01 November, 2021

William, P. C. (2009). The Environmental Impact Assessment Act and the process as an Environmental and Livelihood Advocacy Tool in Defending the Environment. Environmental Defense Newsletter 31(3).

\section{Regulations (Nigeria)}

British Environmental Act, 1990

Criminal Code Act, Cap C38, LFN 2004

Endangered Species (Control of International Trade and Traffic) Act Cap E9, LFN 2004

Environmental Protection Act 1990 S1(2)

Environmental Protection Act, Cap E12, LFN 2004

Federal Environmental Protection Agency Act Cap F 10 LFN 2004

Kanji Lake Park Act, Cap 197, LFN 1990

National Environmental Standards and Regulations Enforcement Agency Act 2007 Cap 301LFN 2010

Oil in Navigable Waters Act, Cap O6, LFN 2004

Oil Pipeline Act Cap O7, LFN 2004

Petroleum Regulations, 1967

The 1999 Constitution of the Federal Republic of Nigeria, Cap C23, LFN 2004

The Land Use Act, Cap L5 LFN2004

Water Resources Act 1993 (Nigeria) 


\title{
PROSPECTS OF INVESTMENT IN DIGITAL ART: THE CASE OF ETHEREUM AND NON-FUNGIBLE TOKEN (NFT)
}

\author{
DOAA SALMAN ABDOU ${ }^{1}$ \\ FATMA ABOU ELNASR ${ }^{2}$
}

\begin{abstract}
This paper focuses on the technology impact via Blockchain to change consumer behavior in the digital art industry. The paper objectives are three folds: first, analyze the impact of Ethereum in selling digital artwork and on the bank world. Second, investigate the effects of Non-Fungible Token on the art industry. Third, highlight how people can sell their artworks, tweets, or even memes for thousands of dollars. Fourth, explain the effect of Ethereum in creating value for artwork and why a meme that includes nothing unique to be sold for an unbelievable price?

The paper provides insights on the future of the digital arts industry and the rational behavior of the developers, artists, and even customers, as the three parties shape the business of the NFL's success. It reflects on the investment behavior in digital arts and the importance of a secure long-term investment for a niche segment that seeks to satisfy their need of acquiring unique products. The paper serves as a guide for digital art and focuses on how AI applications create profitable markets.
\end{abstract}

Keywords: Blockchain, Ethereum, NFT, Crypto art, mining

JEL Codes: L17, L22, L86, L82, O31

\section{Introduction}

The objective of this paper is to analyze the impact of Ethereum on the bank world, and to know the effect of Non-Fungible Token on the art industry, to investigate how people can sell their artworks, tweets, or even memes by thousands of dollars, to explain the effect of NFT on the environment.

Sending money is a simple process that can be done by using any application like PayPal, Apple Pay, or Venmo, these applications are useful and a great option as they keep your money safe and all transactions are secured, even though in the capitalist world they are expensive, as they always try to maximize their profit by applying fees on any transaction. Unlike these apps, Blockchain allows any person to send money safely without using a third party, so no one must pay extra money to cover the transactions fees. Before 2009, Blockchain technology was unknown, it became widely known by launching its first cryptocurrency "the Bitcoin network" and become even more widely known by launching Ethereum cryptocurrency. The core of Blockchain technology was to create a modern cryptocurrency to create secured electronic cash (Nofer, Gomber, Hinz, \& Schiereck, 2017).

\footnotetext{
${ }^{1}$ Prof. of Economics, Head of the Economic Department, October University for Modern Sciences and Arts, Cairo, Egypt, e-mail: dr.doaaslman@gmail.com; dsalman@msa.edu.eg

ORCID iD https://orcid.org/0000-0001-5050-6104

${ }^{2}$ October University for Modern Sciences and Arts, Cairo, Egypt

e-mail: fatma.mohamed15@msa.edu.eg
}

ORCID ID https://orcid.org/0000-0003-3244-0513

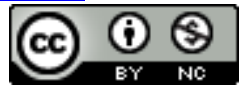

This work is licensed under a Creative Commons Attribution-Non Commercial 4.0 International License. 
Blockchain is a distributed database of a public ledger of all transactions that happened among the participating parties. It is also simply defined as a decentralized ledger. Ledgers are essentially lists that contain who owns what. In Blockchain, they take a copy of the private ledger and make it public -for only the participating parties- then make many copies of these ledgers, and all participating parties maintain their copy, to make sure that all transactions are verified, and nothing is suspicious. No third party is included, so it is decentralized (Gupta, 2017). Blockchain Contains a large database that needs to be hosted on servers made of powerful computers, those servers are built of thousands of computers to have the power and capacity to make it easy and possible to let users access the database. In simple words Blockchain sort data into groups and we can call those groups "blocks", every block has a specific storage capacity when filled the block is chained onto the previse filled block, so they create the "Blockchain", so blockchain is as the name suggest it is a chain of blocks (Filippi, Shimony, \& Fornés, 2021).

The rest of the paper is organized into nine sections: the first section is the introduction in which it introduces the topic and the aim of the paper, Section 2 is the literature review in which it will discuss the history of Ethereum and new trends in the digital art. The third section focuses mainly on the impact of Ethereum on digital art, and how artists double their profit by using Non-Fungible Token. The fourth section will discuss the future of NFTs. The fifth section will summarize the main points in this paper and suggestion of some recommendations.

\section{Literature Review}

Although Ethereum is decentralized digital money, it has failed to achieve its primary goal of real decentralization, as Ethereum has been classified as an oligopoly business. Even though Ethereum's structure does not need to be centralized, it has a track record of limited participation. It's not easy to get Ethereum; you'll need entities known as miners. Miners' primary goal is to record and verify transactions. The Ethereum community is concerned about the concentration of power. Ethereum's developer, Vitalik Buterin, designed it to be decentralized. Unfortunately, the Proof of Work mechanism - which is used to mine Ethereum - provides incentives, and these incentives lead to a system of centralization, which is the polar opposite of what Buterin desired (Vujičić, Jagodić \& Ranđić, 2018).

Mining power is very concentrated, as the cost for mining is not symmetric. Therefore, market share is determined by a simple equation, the one who has a higher ability to pay and get more mining power is the one who has a higher market share. The major reason behind why no one predicted that Ethereum would become not fully decentralized is that there are many studies prove that the more invested in mining the less to be gained from the mining process, as each mining device will decrease the gain from the other device (Dannen, 2017). Unluckily, such studies were incorrect, as numerous factors might reduce the costs of new mining devices. For example, one of the reasons why new devices would cost more is that power would be more expensive. People managed to solve this problem by putting their mining devices in countries with cheap electricity, like China for example. China is the best location for the mining process, which is why China is the basement of Ethereum mining. In China the cost of electricity, cooling hardware is a little bit rational for investors. As a result, they can put up a large number of Ethereum mining devices and increase their mining return without lowering their marginal income. As a result, the Ethereum sector became more centralized, and TTM Digital Assets \& Technologies now has a huge market share (Feng, Niu, Zhang, Wang \& Cheng, 2019).

Ethereum was created to replace PayPal and Visa as they are centralized and authorized currencies. Customers were unhappy because they were bewildered that they paid fees to move their money and that the money merely went to the CEO's pocket, and they were also confused and concerned that all of their transactions might be easily revealed. The developer of Ethereum 
guaranteed that no one or even entity has the authority to freeze client assets or divulge transaction history, hence the goal of Ethereum was to demolish CEOs or any corporation that has the authority to know any transaction at any time. Instate of creating an entity that maintains the record of transactions, there are billions of miners that maintain records (Panescu \& Manta, 2018). The big challenge for Ethereum was how to keep the consistency of the Blockchain. They secure the consistency by a very strict protocol that it is difficult to change anything in the ledger by making every block join to the solution of a complex crypto puzzle. This crypto puzzle is designed to make the first one who guesses the right solution of the puzzle, is the one who gains Ethereum reward. Guessing the solution is the mining devices' mission. When Vitalik Buterin created Ethereum, he had to find a way to confirm transactions in the Blockchain without a third party. Consequently, he used the proof of work model (Dannen, 2017). Mainly, proof of work is used to make nodes know how to secure transactions, to make sure that every transaction is valid, to make sure that no one can break the chain of the Blockchain and put fake block inside the chain, and to make sure that no one is selling his Ethereum twice (Tikhomirov, 2017).

Proof of work depends on a mathematical form called cryptography, and this is why Ethereum is called cryptocurrency. Proof to work uses very complex equations that no one can solve except powerful devices. Once the equation is solved, it can't be repeated twice, which makes every Ethereum unique, as the solution of the equation makes a unique ID for the new Ethereum that is created (Natoli \& Gramoli, 2016). Although proof to work is a successful method, it has several flaws, including the requirement for powerful devices and a large amount of electricity, as well as the fact that this system can only handle a limited number of transactions at once. There is a lot of evidence that mining Ethereum contributed to global warming. Thus developers tried to come up with a new way to mine Ethereum. In 2012, Scott Nadal and Sunny King developed new consensus mechanisms called proof of stake. At first mining, Ethereum by this model cost $\$ 150,000$ for electricity per day. Later, they managed to develop this model to consume less electricity. Unluckily, Ethereum has had a lot of difficulties adopting the proof of stake model; till today, no proof of stake data has been confirmed, therefore there is no document or other evidence that Ethereum has successfully transitioned from Proof of Work to Proof of Stake (Sajana, Sindhu \& Sethumadhavan, 2018).

By using Ethereum you can buy Xbox games, book a hotel on Expedia, or even invest in it and sell Ethereum after with a higher price. One of the most recent ways to use Ethereum is to get a digital wallet and connect it to some of the crypto art websites and buy some NFTs (Non-fungible tokens). NFT is a fresh business that started in 2017. Therefore, only a few studies are made about this business. NFT is a unique asset that cannot be exchanged with another NFT, as it is a Non-fungible token (Trautman, 2021). What do non-fungible tokens mean? In simple words, it is something that cannot be easily swapped or divided up, to simplify it USD can easily be exchanged with the Egyptian pound, and on the other hand, no one can exchange The Last Supper by Leonardo da Vinci for The Starry Night by van Gogh, both artworks do not have the same value for everyone. One can see The Last Supper painting as worthless and the other as priceless, it's all based on opinion. The same thing applied in the NFT business, there is no NFT that has the same value as the other NFT, so NFTs cannot be exchanged with another NFT. NFT is not a stable business to invest in, as it has no real value. The only value it has is the value the media gives to them (Franceschet, 2020).

\section{NFTs opportunities and challenges}

It is used to prove that a digital asset is unique and therefore not interchangeable. NFT can be used to represent digital assets like images, movies, audio, etc. NFTs are electronic tokens that can be used to buy and trade digital art. However, unlike a painting, which may be exhibited in a buyer's home, an NFT is more equivalent to a piece of paper saying that you own 
something, digital artwork, or a movie. Occasionally, a strange-looking cat will appear (Kastrenakes, 2021).

NFT is a new trend that not everyone knows about. OpenSea, Mintable, and Rarible are the most popular platforms that allow you to buy NFT. Most of these sites do not deal in digital currencies but deal in cryptocurrencies. OpenSea, Mintable, and Rarible platforms are working just like eBay, when you want to buy an NFT, you can bid on it. The one who sets the higher bid is the one who gets this NFT. Unlike any internet auction site, the purchasing process is not done by using the USD, trading in OpenSea, Mintable, and Raible are done by using cryptocurrencies. The popular cryptocurrency for buying NFTs is Ethereum and Bitcoin. Cryptocurrencies, in simple word, it is digital assets, and it can be definite also as secure electronic cash. In OpenSea, Mintable, and Rarible no one can use the USD, so the buyer needs to convert his dollars into Ethereum and put them in a digital wallet (Clark, 2021).

The fundamental problem with cryptocurrencies is that they enable people to undertake large-scale transactions that the government cannot easily trace. It promotes tax evasion, money laundering, criminality, and terrorism, all of which governments cannot allow quietly. However, central banks and regulators have been slow to respond. Long-term growth is possible for Bitcoin and other cryptocurrencies (Reyburn, 2021). The initial purchase of NFT was motivated by a desire to collect. These crazes were driven by people who wanted to own these objects rather than trade them. Different collectibles become popular for a variety of reasons, but they all appear to have something in common: a desire for control and order. However, the point is that such objectives did not always involve a desire to get wealthyLater, speculators and investors recognized that the enormous demand for these items meant that if you bought the correct ones, you might make a lot of money, which fueled even more demand, driving prices further higher, and so on (Surowiecki, 2021).

\section{NFT System and how it operates?}

Buying NFTs is a process that not many people would understand. NFT space will grow fast, so people will want it to become more accessible. The process of buying NFTs has some barriers. A lot of platforms that sell NFTs require the buyer to use his crypto wallet. According to Blockchain.com (2021), only 73 million people have a crypto wallet. It is about $1 \%$ of the population of the world. Some developers aimed to let anyone be an art collector, so they developed user-friendly platforms. Those platforms accept credit card payments. Nifty Gateway is one of those platforms that allow users to buy using their credit cards. Nifty Gateway is a centralized platform, as this platform does not require buyers and sellers to have a crypto wallet. The only one who owns a digital wallet is the platform and it is called "Nifty Gateway Omnibus Wallet". All NFTs there are owned by Nifty Gateway-omnibus. That may make it easy for buyers, but this centralizing service made user account vulnerable. Several Twitter users stated that their Nifty Gateway accounts had been hacked and NFTs valued thousands of dollars had been stolen. This brings up another important point about NFTs: they are equally as susceptible to hacking as your email or other online accounts (Schneider, 2021).

After Gateway was hacked, owners announced that their website was not hacked, the stolen items were because account owners did not secure their accounts, they also advised them to use two-factor authentication to secure their accounts (Schneider, 2021). Two-factor authentication (2FA) is a security solution that necessitates the use of two distinct forms of identity to obtain access to anything. A password is usually the first factor, followed by a text message with a code sent to your smartphone or biometrics like your fingerprint, face, or retina (Wallace, 2020). Every transaction, even those that are effectively theft, is nearly permanent due to the immutability of the Blockchain record and the lack of a centralized authority to oversee it. It is irrevocable for both the account owner and the NFT. If they gain access to your 
NFT account and transfer the NFT to them, they are the owner. You have no control over the situation. There is no central authority to rely on, and there is no bank to call (Schneider, 2021).

\section{NFT customers}

When you buy an NFT from one of the different NFT marketplaces, you are paying for a token that symbolizes a unique object. In other words, you're paying for a very small digital record, usually only a few bytes in size that often contains a URL or a serial number and is sent to your Blockchain address. Possession of an NFT is similar to possession of a house's deeds. The deeds, not the house, serve as proof of ownership. Similarly, an NFT is a record of the ownership or legality of an asset, not the thing itself (Nightihgale, 2021).

When a person purchases an NFT, they can gain access to the unique token, but only on the Blockchain. When someone buys an image or meme, they can claim ownership on the Blockchain, but they cannot control how it is distributed. When you purchase an NFT, you are typically purchasing a token that links your name to the artist's work on the Blockchain. It's impossible to predict if NFTs will hold their value in the long run. Billionaire Mark Cuban told Insider that buying NFTs is motivated by scarcity. The buyer knows that there is only one token was made. Buyers are not necessarily fans of the artists. Many buyers are investors. NFTs can function similarly to any other speculative asset in that you buy it and hope that the value of it rises one day so that you can sell it for a profit (Kay, 2021).

One of the most obvious benefits of buying art is that you may financially support artists you admire. When you buy an NFT, you usually get some basic usage rights, such as the ability to share the image online or use it as your profile picture. Of course, owning the painting comes with bragging rights, as well as a Blockchain entry to verify it (Clark, 2021). To buy NFT you will not be obligate to pay only the certain amount of money that the sellers require. There is a hidden cost called gas fees. Simply gas fees are the payment that buyer and seller have to pay to compensate for the computer power necessary to process and validate transactions on the Ethereum blockchain. Because Ethereum transactions need the expenditure of processing energy, the Blockchain imposes a gas fee based on the Ethereum metric of Gwei on users. Gwei is simply a little amount of Ethereum that is used to calculate the costs associated with transaction processing. On most NFT platforms, buyers pay a gas cost to validate a transaction on the Blockchain network using their digital wallet. Sellers may also pay for gas to list and sell NFTs. The price of gasoline varies greatly depending on the time of day. Buyers and sellers can save a lot of money by waiting for gas prices to decline. While you may not be able to avoid paying for gas, you can always lower the expense. Actual charges are difficult to estimate because NFT gas fees vary based on the size of the digital asset and the complexity of the transaction.

There are a lot of fees that any platform takes when anyone tries to sell an NFT. These fees vary from one platform to another. Opensea the largest NFT platform gets a $2.5 \%$ fee on the sale price. Seller is not required to pay gas fees, gas fees are on the buyer that makes Opensea popular with sellers, as they are only charged $2.5 \%$ on the sale price. Another reason for the platform's popularity among sellers is that sellers can charge consumers a 2.5 percent fee. The Nifty Gateway platform also functions as an NFT marketplace. Sellers can seek a 550 percent commission on secondary sales using Nifty Gateway. On secondary sales, Nifty Gateway receives a 5\% commission plus a $\$ 0.30$ charge. There are no petrol fees; they only apply when withdrawing money from an ATM. That means dealers can list and sell NFTs without having to pay for gas. The reason why Nifty Gateway does not apply any gas fees is that Nifty Gateway is a centralized website, which has its digital wallet called "Nifty Gateway Omnibus Wallet". This wallet contains all of the transactions conducted on this website. Nifty Gateway-omnibus owns all of the NFTs in the area (Schneider, 2021). 
First and foremost, NFT is predicated on trust, belief in the value of these tokens. Buyers are simply purchasing metadata that describes what they have purchased. That faith isn't placed in the correct place. The system that NFT employs is extremely risky. For the buyer of the $\$ 69$ million NFT that Beeple sold at Christie's, this system produced the most costly 404 ERROR. The artist's identity, the title of the work, and the NFT itself have all vanished from Christie's.

That isn't a problem in Beeple's NFT; it's simply the way the system operates (Iyengar \& Sarlin, 2021). NFTs use connections to send you to another area where the art and any information about it are preserved. This is a crucial weakness in the NFT system that ensures an NFT remains intact. Links can and do go down, as anyone who has used the internet knows. The NFT provides information on where to locate a description of the artist's identity and the work's title, although such information is rarely seen on the Blockchain. NFTs include directions for finding the artwork they represent.

NFTs face significant hurdles when using traditional URLs. The domain owner may redirect the URL to somewhere else, or they may simply forget to pay their hosting subscription, and everything goes away. Grimes' animation, which sold for $\$ 389,000$, is mostly sourced from a pair of traditional URLs, which might fail if one of the two firms (Nifty Gateway, the auction platform, or Cloudinary, the webserver) goes down. Unless you were wealthy enough to buy the entire domain and pay to keep it online, you would have no control as the buyer (Kastrenakes, 2021).

\section{NFT Future}

Dataset used in this paper comprises 1,912 daily observations from June 22, 2017, to October 312021 on the NFT sales volume in USD, NFT Art sales in million USD, NFT Games sales in million USD, and NFT Art sales in million USD. All datasets are collected from NonFungible Corporation (NonFungible, 2021).

Figure 1: NFT sales in Billion USD

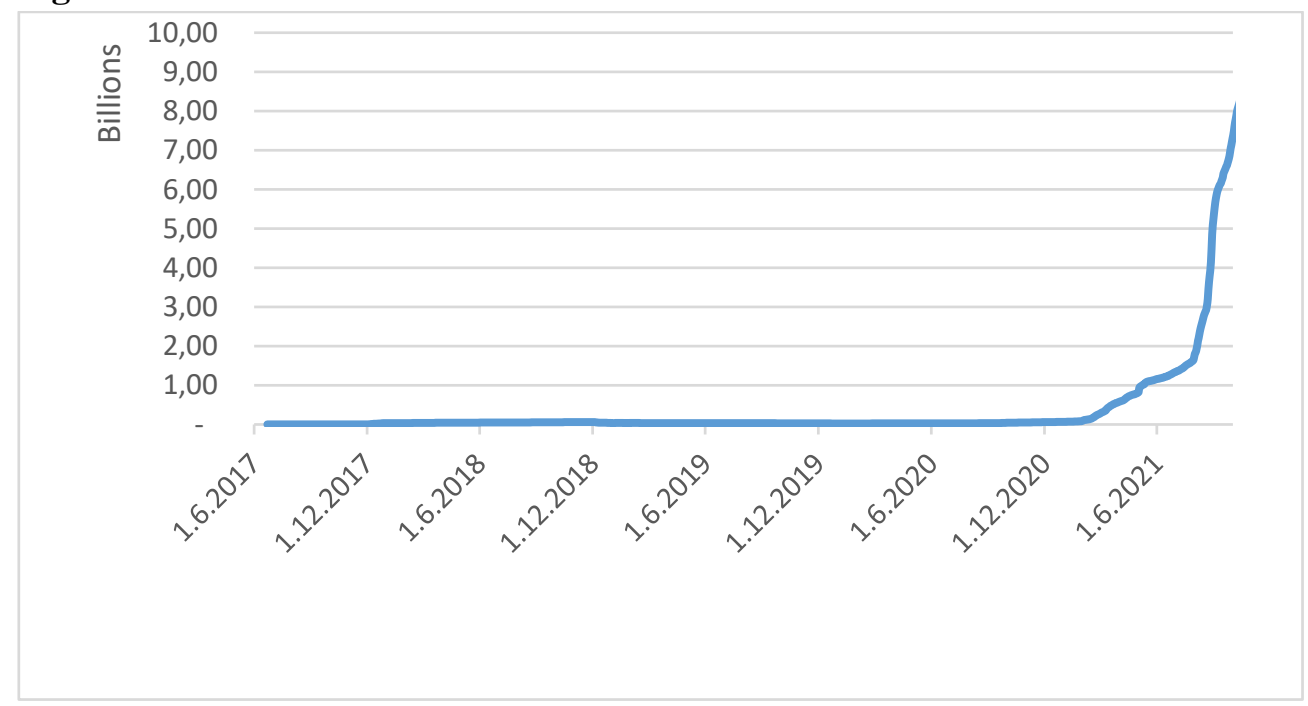

Source: NonFungible, NFT Market History

Figure 1 represents the volume of NFT sales in billion USD during the period from 2017 to 2021. It shows that there was an intense increase in the NFT sales during the end of 2020. Sales jumped from $\$ 66$ million on December 31, 2020, to become $\$ 575$ million. During the year 2017, the volume of NFT sales reached \$33 million. This volume increased to become 58 million at the end of 2018. Sales did not increase at all in 2019. It declined to become 23 
million which was lower than NFT sales in 2017. During the quarantine and the extreme media coverage of NFT sales increased and became billions not millions during early 2021, sales were \$2billion. In October 2021, sales reached \$ 9 billion. Needless to say, that the NFT market is growing rapidly.

Figure 2: Number of active NFT wallets

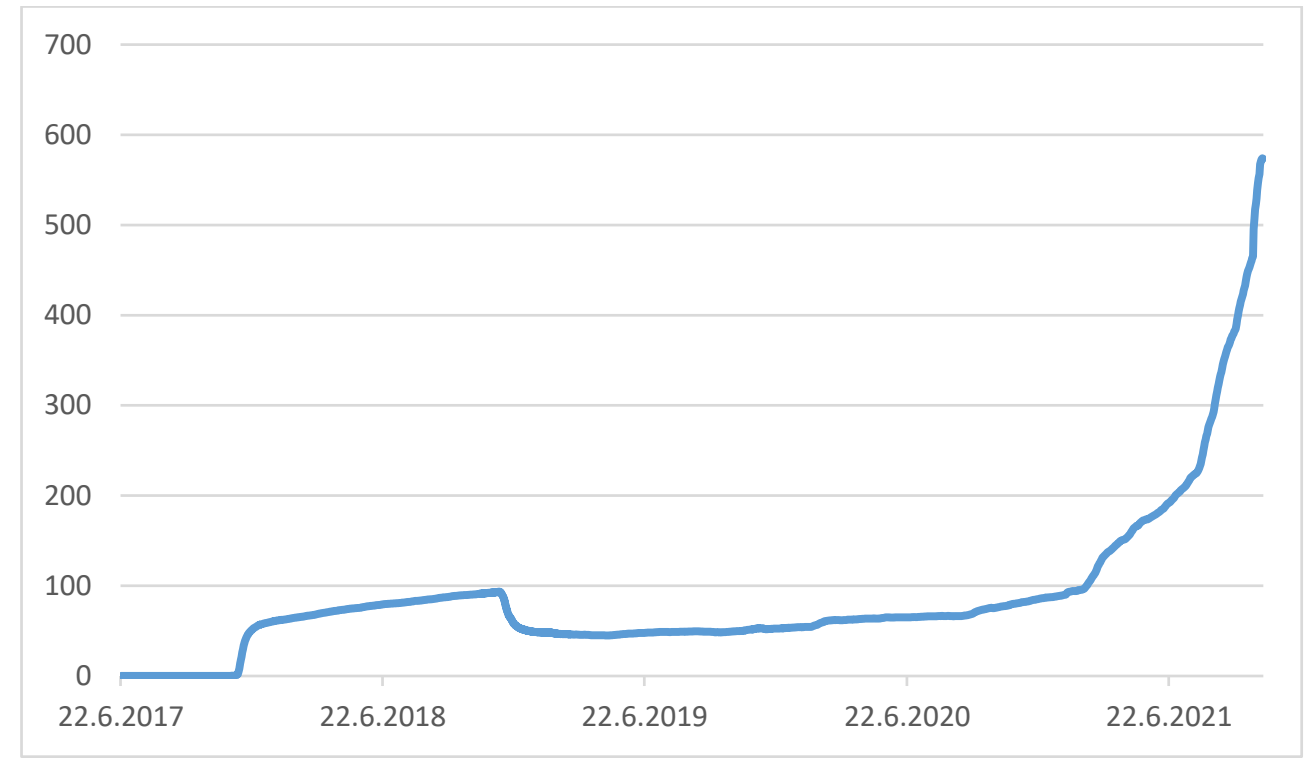

Source: NonFungible, NFT Market History

This graph shows the number of wallets that bought or sold an NFT during the period from 2017 to 2021. This data shows the number of people who are interested in NFT. There was around 2 thousand wallet interaction during June/November 2017, this number increased to reach its max during this year to be 56,279 active wallets. The number of new wallets interacting with NFT kept increasing during 2018 to reach 92 thousand wallets. Needless to say that during the Quarantine the number of active wallets increased to reach 8 million wallets. There was an extreme increase in active wallets since early 2021 due to the peak of media coverage.

It should also be emphasized that during epidemics, when people spend a lot of time indoors, there is a lot of frenetic speculating in assets that have no physical substance. Between 1635 and 1636, tulip mania coincided with a bubonic plague outbreak in the Netherlands, which killed one-fifth of Amsterdam's population (Cuthbertson, 2021).

Concerns about the environment may be one-factor dampening interest in NFTs. Another potential is a drop in the value of Bitcoin and Ethereum, which are related to NFT values. According to Ante (2021), Bitcoin and Ethereum pricing affect NFT sales, but NFT sales do not affect the price of Bitcoin and Ethereum. A drop in Bitcoin and Ethereum value will cause affect negatively the NFT sales.

\section{Conclusion}

NFT is a new product where a group of people perceives it as a craze behavior during 2021. The paper tries to answer if this crazy behavior can secure a long-term investment or not? The paper shows that human behavior of buying unique things is not new where people will repeat what old does. Customers of cryptocurrency are more than satisfied with this currency as it is secured and there is no third party in any transaction that occurs. No one can fake any transaction as the whole devices in the blockchain are maintaining transactions and every transaction should be verified by all devices. The existence of NTFS in the art industry 
made more profit for artists. It even made them get profit from things they did not think they could sell, like memes, and tweets. NFTs are a new business that needs a lot of studies to know how to get more profit from it. No one knows how the NFT market will evolve over the next few years or decades.

Even though many experts believe that NFTs are here to stay, many others believe that the industry is a bubble. In this paper we analyzed NFT sales and the number of active wallets to examine the real number of people who are interested in NFT, finding that there are 2 main peaks in the active wallets first one in late 2017, the second in late 2020 . We also found that NFT sales are dependent on cryptocurrency prices. NFT is a new industry that not many researchers have done on it. NFT theft is an issue that has yet to be entirely resolved. The recommendation in this paper emphasizes the importance of rationality and thinking twice before entering this business in order not to lose huge amounts of money, as in this business anyone can either get high profit or lose a huge amount of money, as this business deponents on the price of the cryptocurrency.

\section{Acknowledgment}

The author is grateful to Dr. Asmaa S. Abdou for her feedback and support to insights and provides links to different aspects in the paper. 


\section{References}

Ante, L. (2021). The non-fungible token (NFT) market and its relationship with Bitcoin and Ethereum. Blockchain Research Lab. Retrieved from http://dx.doi.org/10.2139/ssrn.3861106.

Blockchain.com. (2021). The total number of unique Blockchain.com wallets created. Retrieved from https://www.Blockchain.com/charts/my-wallet-n-users.

Clark, M. (2021). NFTs explained. THE VERGE. Retrieved from https://www.theverge.com/22310188/nft-explainer-what-is-Blockchain-crypto-artfaq.

Cuthbertson, A. (2021). How Bad are Nfts for the Environment? Independent. Retrieved from https://www.independent.co.uk/climate-change/sustainable-living/nftenvironment-climate-change-crypto-b1835220.html.

Dannen, C. (2017). Introducing Ethereum and solidity. Apress, Berkeley, CA. Retrieved from https://link.springer.com/book/10.1007/978-1-4842-2535-6

De Filippi, P., Shimony, O., \& Tenorio-Fornés, A. (2021). Reputation. Internet Policy Review, 10(2). Retrieved from: https://doi.org/10.14763/2021.2.1547.

Feng, Z. K., Niu, W. J., Zhang, R., Wang, S., \& Cheng, C. T. (2019). Operation rule derivation of hydropower reservoir by k-means clustering method and extreme learning machine based on particle swarm optimization. Journal of hydrology, 576, 229-238. Retrieved from https://doi.org/10.1016/j.jhydrol.2019.06.045.

Franceschet, M. (2020). Art for space. Journal on Computing and Cultural Heritage (JOCCH), 13(3), 1-9. Retrieved from https://doi.org/10.1145/3402443.

Gupta, S. S. (2017). Blockchain. The foundation behind Bitcoin [Slides]. Retrieved from https://www.isical.ac.in/ debrup/slides/Bitcoin.pdf

Iyengar, R., \& Sarlin, J. (2021). NFTs are suddenly everywhere, but they have some big problems. Action News Now. Retrieved from http://bridge-

stage.occipital.com/books/content.php?filename $=$ eric.cole $\&$ pub $=0 \mathrm{f} 72 \mathrm{be} 95305 \mathrm{f} 517 \mathrm{~d} 8$ $\underline{585653 \text { cad5faad4. }}$

Kastrenakes, J. (2021). Your Million-Dollar Nft can Break Tomorrow if you're Not Careful. THE VERGE. Retrieved from https://www.theverge.com/2021/3/25/22349242/nftmetadata-explained-art-crypto-urls-links-ipfs.

Kay, G. (2021). Selling crypto art can come with huge hidden fees, leading some people to lose hundreds of dollars. Business Insider. Retrieved from https://www.businessinsider.com/nft-investing-crypto-art-what-is-a-gas-feeexplained-2021-3. 
Natoli, C., \& Gramoli, V. (2016). The blockchain anomaly. In IEEE 15th International Symposium on Network Computing and Applications (NCA), pp. 310-317. Retrieved from DOI: 10.1109/NCA.2016.7778635.

Nft's street. (2021). How much does it cost to sell NFT art? NFT'S STREET. Retrieved October 10, 2021 from https://www.nftsstreet.com/how-much-does-it-cost-to-sell-nft$\underline{\operatorname{art} / .}$

Nightihgale, R. (2021, March 29). What do you actually own if you buy an NFT? Makeuseof. Retrieved October 10, 2021, from https://www.makeuseof.com/what-do-you-actuallyown-if-you-buy-an-nft/.

Nofer, M., Gomber, P., Hinz, O., \& Schiereck, D. (2017). Blockchain. Business \& Information Systems Engineering, 59(3), 183-187. Retrieved from https://doi.org/10.1007/s12599-017-0467-3

NonFungible. (2021). NFT Market History. Retrieved from https://nonfungible.com/market/history.

Panescu, A. T., \& Manta, V. (2018). Smart contracts for research data rights management over the ethereum blockchain network. Science \& Technology Libraries, 37(3), 235245. Retrieved from https://doi.org/10.1080/0194262X.2018.1474838

Reyburn, S. (2021, March 30). Art's NFT Question: Next Frontier in Trading, or a New Form of Tulip? The New York Times. Retrieved October 10, 2021, from https://www.nytimes.com/2021/03/30/arts/design/nft-bubble.html.

Sajana, P., Sindhu, M., \& Sethumadhavan, M. (2018). On blockchain applications: hyperledger fabric and ethereum. International Journal of Pure and Applied Mathematics, 118(18), 2965-2970. Retrieved from https://www.acadpubl.eu/jsi/2018118-18/articles/18c/84.pdf

Schneider, T. (2021, March 22). The Gray Market: Why the Hack of Nifty Gateway Raises Far-Reaching Questions About the Entire NFT Market. Artnet News. Retrieved October 10, 2021, from https://news.artnet.com/opinion/nifty-gateway-nft-hack-graymarket-1953549.

Surowiecki, J. (2021, March 8). Why the NFT Craze Is a Bubble Waiting to Pop. Marker. medium. . Retrieved October 10, 2021, from https://marker.medium.com/why-the-nftcraze-is-a-bubble-waiting-to-pop-ad35922ca210.

Tikhomirov, S. (2017). Ethereum: state of knowledge and research perspectives. Foundations and Practice of Security, 206-221. Retrieved from https://www.springerprofessional.de/ethereum-state-of-knowledge-and-researchperspectives $/ 15471472$.

Trautman, L. J. (2021). Virtual Art and Non-fungible Tokens. SSRN 3814087. Retrieved from http://dx.doi.org/10.2139/ssrn.3814087. 
Vujičić, D., Jagodić, D., \& Ranđić, S. (2018, March). Blockchain technology, bitcoin, and Ethereum: A brief overview. In 17th international symposium INFOTEH-JAHORINA (INFOTEH), IEEE, 1-6. Retrieved from http://dx.doi.org/10.1109/INFOTEH.2018.8345547.

Wallace, B. (2020, March 2). The Twin Blockchain Entrepreneurs Who Dream of "Digital Air Jordans". New York Magazine. Retrieved from: https://nymag.com/intelligencer/2020/03/duncan-and-griffin-cock-foster-niftygateway-gemini.html. 


\title{
IDEALIZATION OF ESTABLISHING THE PROFESSIONAL DATA PROTECTION OFFICER FOR FINANCIAL TRANSACTION MANAGEMENT IN INDONESIA: REFLECTING ON EUROPEAN UNION
}

\author{
CARISSA CHRISTYBELLA WIJAYA ${ }^{1}$ \\ FAJAR SUGIANTO ${ }^{2}$ \\ RIZKY P.P. KARO KARO ${ }^{3}$ \\ TOMY MICHAEL ${ }^{4}$
}

\begin{abstract}
In the current digital era, digital economic and financial transactions are increasing rapidly in line with the use of digital platforms during the pandemic caused by Large-Scale Social Restrictions (PSBB). The growth was offset by the rampant cases of personal data leakage in digital financial transactions in Indonesia. Besides, personal data itself is a person's personal right that must be protected as best as possible and efforts to protect personal data for users of digital platforms is needed. The application of a Data Protection Officer that reflects the General Data Protection Regulation is the right solution for protecting personal data. This research was conducted with the aim of giving companies and consumers confidence in the Data Protection Officer as an independent institution capable of protecting personal data on digital platforms. The research method used is juridical normative with a statute approach, a case approach, and a comparative legal approach. The results and conclusions of this study are that it is necessary to formulate a regulatory formulation for the Data Protection Officer profession so that it can function according to its protection function
\end{abstract}

Keywords: Data Protection Officer, Digital Era, Financial Transactions, Profession

JEL Codes: F38, K38

\section{Introduction}

In the Industrial Revolution 4.0, all activities in aspects of human life are closely related to digital access. Now, human productivity is assessed through the efficiency of technology which plays an important role in improving the standard of living of the nation. Along with the rapid development of the digital era, especially in information and communication technology which was previously not carried out thoroughly online, is currently experiencing a transition period where all activities switch digitally. This happened in connection with the conditions of the world affected by the COVID-19 pandemic. The public is required to carry out all activities from home, from meetings to financial transactions to obtain the necessities of daily life that are carried out remotely through online media. This situation cannot be avoided by various

\footnotetext{
${ }^{1}$ Faculty of Law, Pelita Harapan University, Indonesia. E-mail: carissachr@gmail.com

ORCID IDhttps://orcid.org/0000-0001-5627-4834

${ }^{2}$ Faculty of Law, Pelita Harapan University, Indonesia. E-mail: fajar.sugianto@uph.edu

ORCID ID https://orcid.org/0000-0002-5969-4495

${ }^{3}$ Faculty of Law, Pelita Harapan University, Indonesia. E-mail: rizky.karokaro@uph.edu

ORCID iD https://orcid.org/0000-0002-2361-6903

${ }^{4}$ Faculty of Law, Universitas 17 Agustus 1945 Surabaya. E-mail: tomy@untag-sby.ac.id ORCID iD https://orcid.org/0000-0003-1707-6119
}

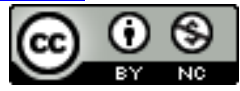

This work is licensed under a Creative Commons Attribution-Non Commercial 4.0 International License. 
nations so that readiness to face the digital era is very much needed in order to improve the quality of life of the world community.

The pandemic period also had a significant impact on the Indonesian people, which was marked by the acceleration of digitalization, especially in the economic field. As can be seen from the increase in digital financial transactions through the use of digital platforms during the pandemic caused by Large-Scale Social Restrictions ("PSBB") until now it has developed into the Enforcement of Restrictions on Community Activities ("PPKM") so that the community's space for movement is very limited. The implementation of the PSBB has a real impact, namely the strengthening of public preferences and acceptance for digital transactions. The increase in digital financial transactions that occurred in Indonesia can be strengthened based on electronic money transaction data according to Bank Indonesia, namely, in October 2020 , the value of electronic money transactions reached $\mathrm{Rp} 18.79$ trillion with a volume of 392.88 million transactions. This achievement shows that throughout 2020, October had the highest value of electronic money transactions. Meanwhile, in terms of volume, the largest occurred in January with 457.94 million transactions worth Rp 15.87 trillion (Malik, 2020).

In more detail, the author will provide data related to the increase in digital financial transactions, both in the form of digital banking, financial technology ("fintech"), electronic wallet ("e-wallet"), to electronic commerce ("e-commerce") transactions. First, in the scope of digital banking, there was an increase in PT Bank Rakyat Indonesia Tbk which recorded that throughout May 2020 there was an increase of $100 \%$ in BRImo mobile banking transaction services, when compared to before the Government announced the COVID-19 pandemic in early March 2020 with an average number of transactions an average of almost 6 million every day. Meanwhile, PT Bank Central Asia Tbk recorded digital payment growth of $20 \%$ to $30 \%$ with account opening via video banking reaching 5,100 accounts per day. Furthermore, Jenius as a digital banking product from PT Bank BTPN Tbk which recorded the addition of new online and organic customers increased by $25 \%$ compared to before the pandemic period.

Second, fintech-based digital payment transactions experienced an increase in transactions, namely new OVO users recorded an increase of $267 \%$ during the pandemic. Third, in the e-wallet, there was a 50\% growth in transactions in the DANA application from January to mid-May. Next, there is the Gopay application, Gojek's e-wallet, which recorded an increase in transactions during the pandemic, which increased by $103 \%$. Fourth, in e-commerce transactions, namely Bukalapak, which recorded an increase of up to 50\% in June 2020 compared to the same month in 2019. Sales at Tokopedia also managed to penetrate 8.6 million in the middle of the year, an increase of 1.4 million compared to January, 2020. Then, Shopee also recorded a 3-fold increase in demand for the food and staple category during the pandemic (Astutik \& Hastuti, 2020). This percentage shows that everything from meeting daily needs to financial transactions can be done efficiently through digital platforms so that one of the effects of the COVID-19 pandemic is the development of digital technology for all aspects of Indonesian people's lives.

The use of various kinds of digital platforms above has become a routine for the community as a form of ease of transacting to meet their daily needs so that the public as users must give full trust to the digital platform which in its arrangement is further managed by the electronic system operator. ${ }^{5}$ In this case, the trust in question is that the public entrusts the electronic system operator to manage all information regarding their personal data submitted as a mandatory requirement for using the digital platform. Personal data itself can be interpreted as single information or a collection of information, whether confidential or not, provided by

${ }^{5}$ Article 1 number 4 of Government Regulation Number 71 of 2019 concerning the Implementation of Electronic Systems and Transactions reads, "Electronic System Operators are any Person, state administrators, Business Entities, and the public who provide, manage, and/or operate Electronic Systems individually or together with Electronic System Users for their own needs and/or the needs of other parties." 
the owner of the personal/consumer data and collected into an electronic system that is processed by the electronic system operator to be used in accordance with its purpose and use. If the electronic system operator does not manage data properly, then the consequences of personal data leakage can occur, and also if misused, the owner/ consumers can resolve it through civil law media and/or criminal law media (Agren, Bjelkmar \& Allison, 2021). In connection with the rise of digital financial transactions, if there is a leakage of personal data on the digital platform, it can potentially cause financial losses to threaten the security and safety of the owner of the personal data that is harmed (Hutchinson \& Treščáková, 2021).

Since the beginning of 2020, there have been several cases of personal data leakage in Indonesia, namely:

Table 1. Some of Personal Data Leakage Cases in Indonesia in 2020

\begin{tabular}{|c|c|l|}
\hline No. & Platform Digital & \multicolumn{1}{c|}{ Number of Data Misuse } \\
\hline 1. & Tokopedia & $\begin{array}{l}\text { At the beginning of May 2020, as many as 91 million user data and more } \\
\text { than 7 million Tokopedia merchant data were reportedly sold on dark } \\
\text { websites. }\end{array}$ \\
\hline 2. & Bhinneka.com & $\begin{array}{l}\text { A group of hackers by the name of ShinyHunters claims to have sold 1.2 } \\
\text { million Bhinneka.com customer data in May 2020. }\end{array}$ \\
\hline 3. & KreditPlus & $\begin{array}{l}\text { KreditPlus user data leaks are described in a report from the cybersecurity } \\
\text { firm from the United States, Cyble. Based on the report, personal data } \\
\text { belonging to around 890,000 KreditPlus customers was allegedly leaked } \\
\text { in August 2020. }\end{array}$ \\
\hline 4. & RedDoorz & $\begin{array}{l}\text { The founder of the Indonesian Ethical Hacker community, Teguh } \\
\text { Aprianto revealed that there were 5.8 million data on RedDoorz users } \\
\text { which were sold for US } \$ 2,000 \text { or around Rp 28.2 million in November } \\
\text { 2020. }\end{array}$ \\
\hline 5. & Cermati & $\begin{array}{l}\text { At the beginning of November 2020, around 2.9 million data from } \\
\text { Indonesian fintech platform users, namely Cermati, were reportedly } \\
\text { hacked and sold freely. }\end{array}$ \\
\hline
\end{tabular}

Source: Stephanie (2021)

Based on several cases of data leakage on digital platforms used by the public, it can be seen that there is an urgency for the protection of personal data in Indonesia. Previously, it should be realized that personal data is a fundamental right that exists in every person's personality. Based on the Indonesian constitution which is stated in Article 28G paragraph (1) of the 1945 Constitution of the Republic of Indonesia, namely, "Everyone has the right to protect himself, his family, honor, dignity, and property under his control, and has the right to a sense of security and protection from the threat of fear to do or not do something which is a human right." The statement relates to the purpose of protecting personal data based on the ratio legis in the Bill on the Protection of Personal Data as of January 2020 ("RUU PDP"), which is to guarantee the right of citizens to personal protection and to raise public awareness as well as to guarantee recognition and respect for the importance of protecting personal data.

In this all-digital era, the public must realize that the protection of personal data is a very important effort as a part of privacy rights to monitor access to information about a person's life and personal data. In accordance with Article 26 paragraph (1) of Law Number 11 of 2008 concerning Information and Electronic Transactions as amended by Law no. 19 of 
2016 ("UU ITE") which states that, "Unless otherwise stipulated by the Laws and Regulations, the use of any information through electronic media concerning a person's personal data must be carried out with the consent of the person concerned". Protection of personal data is an effort that must be enforced because the more rapid the use of digital platforms, the more misuse of personal data by irresponsible parties. Public trust as users of digital access is at stake if there is no guarantee for the protection and management of personal data in the applicable digital economy system. Therefore, the protection of personal data is very much needed in this digital era. The protection of personal data does not only aim at the respective owners themselves but there needs to be a realization of action from officers who are able to guarantee the protection of personal data in every sector of digital platform companies that act as controllers or processors of personal data (Kaya, 2020).

Officers who play a role in carrying out the function of protecting personal data are listed in the RUU PDP. The idea about the officer was obtained from a regulation established by European countries that are members of the European Union, namely the General Data Protection Regulation ("GDPR") which specifically regulates the protection of personal data and came into force on 25 May 2018. In the regulation, there is a regulation regarding the Data Protection Officer ("DPO"), which is a data protection officer assigned to the internal company. Not only triggering a sense of security for consumers who provide personal data to digital platform companies as providers of electronic systems, the formation of officers who are able to guarantee the protection of personal data can also open up new job opportunities for the people of Indonesia. Along with the development of technological sophistication in the digital era, accompanied by all aspects of human life that are starting to depend on existing information and communication technology, Indonesia can take advantage of it all as an opportunity to improve the standard of living of the nation in accordance with Indonesia's vision of the Industrial Revolution 4.0, namely to create an advanced digital nation (Sinaga \& Putri, 2020).

\section{Method}

In writing a scientific paper entitled "Idealization of the Establishment of a Professional Code of Ethics Commission for Data Protection Officers on Financial Transactions in Indonesia", the research method used by the author is a normative juridical method, namely library law research conducted by examining library materials or secondary data mere (Kurien $\&$ Chikkamannur, 2019). The author uses the scope of research on the principles of law and comparative law.

The data collection procedure used by the author is primary data (primary data), namely the reality in the field, and secondary data (secondary data) sourced from library materials. In this study, the author uses secondary data, namely First, primary legal materials consisting of the 1945 Constitution of the Republic of Indonesia, Law Number 11 of 2008 concerning Information and Electronic Transactions as amended by Law Number 19 of 2016, Government Regulation Number 71 of 2019 concerning the Implementation of Electronic Systems and Transactions, Regulation of the Minister of Communication and Information Technology Number 20 of 2016 concerning Protection of Personal Data in Electronic Systems, Financial Services Authority Regulation Number 13/POJK.02/2018 concerning Digital Financial Innovation in the Financial Services Sector, Circular Letter of the Financial Services Authority Number 14/SEOJK 07/2014 concerning Confidentiality and Security of Consumer Personal Data and/or Information, Draft Law on Personal Data Protection as of January 2020. Second, secondary legal materials such as books, scientific journals, seminar proceedings, and websites. Third, tertiary legal materials such as dictionaries and encyclopedias.

The author uses several approaches that are considered relevant to the issue being researched, namely First, the legal approach is carried out by examining all laws and 
regulations related to the legal issues being handled. Second, the case approach is carried out by examining cases related to the issues at hand. Third, a comparative approach is carried out by comparing the laws of a country with the laws of one or more other countries on the same matter. Furthermore, the author uses qualitative research methods because in processing the data, the author does it by means of a literature study, namely analyzing laws and regulations, legal theories, books, journals, and a number of other literature that can be accounted for. The author also uses descriptive research methods in order to explain the problems and solutions in detail and accurately (Nikkel, 2020).

\section{Formulation of Data Protection Officer Profession Arrangements in Indonesia}

Protection of personal data is very necessary, in addition to being carried out by users of personal data themselves to be managed and maintained so they are not easily hacked, electronic system operators have an obligation to protect information that has been entrusted by users to be managed as well as possible. The increasing use of digital financial transactions must be balanced with appropriate protection measures to protect consumers' personal rights to avoid misuse of personal data. Cases of misuse of consumer personal data that are rife can have an impact on decreasing the level of consumer confidence as all financial transactions currently rely on digital access. Therefore, to restore consumer confidence in the use of digital financial transactions, efforts to protect personal data by electronic system operators must be increased.

In order to protect personal data on the internet, under certain conditions when a company handles consumer's personal information, the GDPR requires the company to appoint a DPO who is in charge of overseeing GDPR compliance. In this case, the DPO or data protection officer is required to have knowledge of the law and expertise in data protection practices. In addition, the GDPR also provides advice for most companies that manage personal data to employ DPOs. As DPO within the scope of the European Union provides a major contribution to the protection of consumer personal data. The role of DPOs in the European Union has avoided severe penalties of up to $4 \%$ of global revenues. If Indonesia participates in implementing the existence of DPO, then the right solution has been found to reduce the occurrence of personal data leakage in this digital era (Wolford, 2018).

The regulation regarding the obligation to appoint DPOs in Indonesia is stated in Article 45 paragraph (1) of the RUU PDP, namely that personal data controllers and personal data processors are required to appoint an official or officer who carries out the function of protecting Personal Data. This provision is closely related to Article 14 paragraph (1) of PP PSTE which regulates the obligations of electronic system operators to implement the principle of personal data protection in processing personal data. With the establishment of the DPO in the RUU PDP, the organizer of the electronic system in processing personal data has the obligation to appoint the DPO as an officer who carries out the function of protecting personal data. More clearly, the company as the operator of the electronic system that controls and processes personal data has an obligation that must be fulfilled, namely appointing a DPO in accordance with statutory provisions. Because it needs to be realized that by appointing a DPO, the electronic system operator has made efforts to protect consumers' personal data.

Furthermore, to provide social security and control in carrying out the obligation to appoint DPOs, there is a provision in the RUU PDP regarding administrative sanctions for electronic system operators who do not comply. When referring to the case that occurred in Spain on June 9, 2020, Glovo Delivery was subject to a sanction in the form of an administrative fine of 25,000 euros for not appointing a DPO in accordance with Article 37 of the GDPR (Divi, 2020). The action taken by the Spanish Data Protection Agency by imposing sanctions on Glovo Delivery is very appropriate because it is able to make other electronic operators aware that DPO is very important in order to protect personal data. The Indonesian 
nation can reflect on this case by enforcing the embodiment of the regulations related to administrative sanctions as stated in Article 50 paragraph (1) of the RUU PDP for electronic system operators who do not meet the provisions of Article 45 paragraph (1) of the RUU PDP regarding the obligation to appoint DPOs. The administrative sanctions referred to in Article 50 paragraph (2) of the RUU PDP are in the form of written warnings, temporary cessation of personal data processing activities, deletion, and destruction of personal data, compensation, and/or administrative fines.

In connection with the implementation of DPO in Indonesia which is in line with the opportunities for new job openings influenced by the development of the digital era, DPOs have their own qualifications in accordance with the provisions of Article 37 of the GDPR, which are stated in Article 45 paragraphs (3) and (4) of the RUU PDP which states that The officer or officer who performs the function of protecting Personal Data must be appointed based on professional quality, knowledge of the law and practice of protecting Personal Data, and ability to fulfill his/her duties. As for recruiting DPOs in a company, they can come from inside and/or outside the Personal Data Controller or Personal Data Processor.

Further to the position of DPOs, Article 38 of the GDPR states that other employees in the organization are not permitted to issue any instructions to DPOs regarding the performance of their duties. So, DPOs not only have broad responsibilities but their positions are also protected from potential interference from the company so as not to misuse personal data based on the independence of their profession. Then, DPOs are also bound by confidentiality in carrying out their duties and will only report tasks related to the company directly to the highest management as stakeholders of the company. In this case, it can be seen that the DPO has significant duties and positions as an independent institution with special expertise that can be occupied by many parties in accordance with applicable regulations (Mulligan, Freeman \& Linebaugh, 2019, p. 42).

DPO is a manifestation of the formation of a new profession in the digital era. To become a professional after the RUU PDP is passed, DPO must be associated with ethical discipline, code of ethics, and certification in the field of law and practice of protecting personal data. The legal characteristics of a profession are having legal standing and in obtaining a job one must go through special training required by law so that a person has the right to serve in that position. DPO as a professional figure, namely a person who has expertise and knowledge in increasing the protection of personal data of digital platform users. Therefore, a person independently must be able to meet the needs of the community in terms of services in fields that require expertise and knowledge. The bearer of the profession concerned will decide what to do in carrying out his/her professional development. They are personally responsible for the quality of the services that they carry out (Sidharta, 2015, p. 228).

In connection with the DPO profession which is adapted to the understanding of the profession, to work as a DPO in a company requires special preparation and knowledge that is guided by skill education. DPOs also need professional ethics to act and take the right attitude in carrying out their profession. With the existence of ethics in a profession, there will be rules and high moral standards so that DPOs can serve the interests of many people to protect their personal data. Ethics will guide DPOs who are professionals in their fields to make decisions. Thus, in the future, professionals will have an ethical discipline that can be developed and applied by DPOs as professionals.

In addition, to establish more specific norms of professional ethics, DPOs can formulate a code of ethics as a basis for carrying out their duties. The code of ethics in question is selfregulation established by the DPO profession itself so that it can animate the ideals and values of the implementation of DPO in Indonesia. The code of ethics is very important as a guideline for every member of the DPO profession regarding the principle of professionalism in carrying out the profession in accordance with the applicable duties and authorities. Therefore, the code 
of ethics must include sanctions for violations if the DPO violates the duties set by the government through the RUU PDP. Sanctions that can be recommended are in the form of moral sanctions to legal sanctions as a means of social control for the community over the DPO profession. With the enactment of the code of ethics, an Honorary Council or Professional Commission can also be formed which is authorized to handle cases of violations of the code of ethics by DPOs. The establishment of a code of ethics in accordance with these provisions aims to ensure that DPOs have full responsibility for the profession they have been engaged in and prevent unethical behavior from occurring (Sugianto, 2017).

After compiling provisions regarding the aspects needed to form DPO into a profession, standardization of standards to train the skills and skills of the DPO profession is also very much needed. This is done to increase the trust of companies that want to appoint DPOs, so that before being assigned to a company, DPOs already have adequate skills to carry out the function of protecting personal data in accordance with existing laws and regulations. In this case, to gather every member of the DPO profession with the aim of training and maintaining skills and conducting professional certification to them, an association can be formed as a statutory mandate to protect personal data.

Provisions regarding steps to make DPOs a profession can be enacted in the RUU PDP by adding a clear systematic to the new article, namely Article 45A which reads as follows:

"(1) In order to maintain the dignity and honor of the profession of officials or officers who carry out the function of protecting personal data, a professional code of ethics is drawn up by the Association of officials or officers who carry out the function of protecting personal data.

(2) Officials or officers who carry out the function of protecting personal data are obligated to comply with the code of ethics and the provisions concerning the Code of Ethics Commission.

(3) The code of ethics commission examines and prosecutes violations of the professional code of ethics of officials or officers who carry out the function of protecting personal data based on the procedures for the commission of the code of ethics.

(4) Officials or officers who carry out the function of protecting personal data as referred to in Article 45 paragraph (3) must meet the standardization of standards prepared by the Association of officials or officers who carry out the function of protecting personal data.

(5) The association of officials or officers carrying out the function of protecting personal data is a free and independent professional forum established in accordance with the provisions of this Law with the aim and purpose of improving the professional quality of the official or officer carrying out the function of protecting personal data."

In relation to the provisions regarding associations, in Indonesia itself there has been the first association for DPOs which was established in 2020, namely the Association of Indonesian Data Privacy Professionals (“APPDI"). It is hoped that the associations that oversee DPOs in Indonesia will be able to guarantee the development of DPOs into a profession with legal stages determined by Indonesian legislation. Thus, the proposal for the addition of Article 45A above can be made before the RUU PDP is passed, as the ratification of the RUU PDP requires a united political will by the legislature. As for the development of the RUU PDP, until this paper was formed in May 2021, it has not been ratified and has only been included in the 2021 Priority National Legislation Program Bill ("Prolegnas"). It can be seen that there is an urgency that the RUU PDP must be promulgated immediately because the formulation is very necessary for the context of ensuring the existence of DPO as a necessity to protect 
individual rights in society. In addition, further provisions regarding the existence of DPOs in Indonesia can be regulated in a Government Regulation and/or Regulation of the Minister of Communication and Information in accordance with the mandate of the RUU PDP. Through adequate protection of personal data, it will be able to provide trust for the public to provide personal data for the greater public interest without being misused or violating their personal rights.

\section{The Role of the Data Protection Officer in Performing the Function of Personal Data Protection for Financial Transactions in Indonesia}

In connection with the above explanation regarding the formulation of the regulation of the DPO profession in Indonesia, it will be closely related to the role of the DPO in carrying out the function of protecting personal data in financial transactions in Indonesia. Each DPO that has been appointed by the company as the operator of the electronic system has the task as stated in Article 46 paragraph (1) of the RUU PDP. In this task, DPOs who are already internal to the company can inform and provide suggestions for personal data controllers or personal data processors to comply with the provisions in the RUU PDP. DPOs can also monitor and ensure compliance with the RUU PDP and policies on personal data controllers or personal data processors, including assignments, responsibilities, awareness-raising, and training of parties involved in the processing of personal data, and audits within related companies. DPOs can provide advice on assessing the impact of protecting Personal Data and monitoring the performance of Personal Data Controllers and Personal Data Processors.

While working within the company internally, the DPO is the party that coordinates and acts as a liaison for issues related to the processing of Personal Data, including conducting consultations on risk mitigation and/or other matters related to their duties in protecting consumer's personal data. Recruitment of DPOs in a company engaged in the digital economy and finance that manages personal data will be very much needed in line with the rapid development of the digital era in Indonesia today. Therefore, users of digital financial transactions as consumers need guarantees that the personal data they share with digital platforms will be safe when managed. Thus, as a preventive measure to avoid errors during data management to the occurrence of personal data leakage, DPOs are required to carry out all their duties in protecting personal data and enforcing the personal rights of consumers.

Based on the data that has been presented by the author in Table 1 regarding several cases of personal data leakage in Indonesia in 2020, if there are 5 digital platforms divided into the realm of digital financial transactions, namely e-commerce and fintech, which have these problems. As for digital financial regulation, it is further regulated in Financial Services Authority Regulation Number 13/POJK.02/2018 concerning Digital Financial Innovation in the Financial Services Sector. A fintech platform is a form of Digital Financial Innovation ("IKD"), so Article 4 states the IKD criteria and in letter $g$ it is written that the IKD criteria must pay attention to aspects of consumer protection and data protection. This shows that the protection of personal data in financial transactions in this digital era is very much needed, as is the existence of DPOs in Indonesia.

In the author's opinion, problems related to personal data leakage can be prevented by preventive measures taken by the company from the five digital platforms. If the RUU PDP and the DPO profession have been passed, companies can appoint DPO as an effort to protect consumers' personal data. The case that happened to Tokopedia was one of the cases of leakage of personal data in a fairly large financial transaction in 2020 yesterday, which amounted to 91 million accounts and 7 million merchant accounts were hacked by irresponsible actors. In 2019, Tokopedia revealed that there were around 91 million active accounts on its digital platform. This means that almost all accounts on Tokopedia have been successfully retrieved by hackers. This case of personal data leakage has caused considerable losses as the perpetrators sold data 
on the dark web in the form of user ID, email, full name, date of birth, gender, phone number, and password that were still hashed or encrypted at a price of US $\$ 5,000$ or around Rp 74 million (CNN Indonesia, 2020b).

The actions taken by Tokopedia related to this problem are First, after knowing the incident, Tokopedia immediately provided information to all Tokopedia users, then started the investigation process and took the necessary steps to ensure that accounts and transactions were maintained. Second, Tokopedia has communicated and collaborated with the government, including the Ministry of Communication and Information and the National Cyber and Crypto Agency to investigate this incident while ensuring the security and protection of consumer personal data. Third, in addition to conducting internal investigations, Tokopedia has appointed a world-class independent institution that specializes in cybersecurity to assist in the investigation and identification of the steps needed to improve data protection for Tokopedia users. Furthermore, Tokopedia also asks users to follow security measures such as changing the Tokopedia account password periodically, not using the same password on various digital platforms, and maintaining OTP by not giving the OTP code to any party, including those on behalf of Tokopedia and for whatever reason (CNN Indonesia, 2020a).

The repressive steps that have been taken by Tokopedia in the case of personal data leakage above, shows that DPO is clearly needed for every company engaged in digital platforms such as Tokopedia to perform the function of protecting personal data as a preventive measure. The preventive function of protection needs to be carried out by Tokopedia so that it can avoid the occurrence of personal data leakage cases that harm consumers to the good name of the digital platform itself. Prevention can be carried out by Tokopedia by appointing DPOs to carry out their duties and work within the company's internal operations to protect consumers' personal data. DPO will also be a liaison between companies and consumers with regard to personal data management, so that in the event of a personal data leakage case carried out by irresponsible parties, DPO will provide solutions and handle it with transparency to the public and the government.

It should be remembered that DPOs as a profession have tools that are able to monitor their work performance, namely the Code of Ethics Commission so that DPOs will be trusted parties in dealing with these problems. Based on the repressive measures that have been taken by Tokopedia, at least it can be seen that Tokopedia appoints a world-class independent institution that specializes in cybersecurity as the institution has the same task as the DPO. Therefore, DPO is the most appropriate measure to be implemented in Indonesia, because DPOs will carry out their duties professionally in protecting consumers' personal data so that digital economy platforms, both Tokopedia and Bhinneka.com, KreditPlus, RedDoorz, and Cermati, also experienced data leaks. According to Table 1, individuals can take protection and prevention to minimize the occurrence of problems like this in the future.

\section{Conclusion}

Based on the formulation of the existing problems, the author concludes that: First, the formulation of the regulation of the DPO profession in Indonesia is very necessary so that it is able to make the DPO as an independent institution with skills that are trained and professionally certified in protecting personal data. Thus, it can give full confidence to the company as the controller or processor of personal data to appoint a DPO as the executor of the function of protecting personal data owned by users of the digital platform. Second, in accordance with the current development of the digital economy, DPOs have an important role, namely to take preventive steps by protecting consumer personal data at companies operating on digital platforms and taking repressive steps by providing solutions in dealing with problems surrounding personal data leakage. With the DPO, it is hoped that it will increase public 
confidence in providing personal data for the greater public interest without being misused or violating their personal rights.

The author also recommends applying the formulation of the DPO profession regulation in Indonesia. Through the initial step for the government, especially the legislature, to immediately ratify the RUU PDP so that social control can be enforced for electronic system operators who do not carry out the obligation to appoint DPOs in accordance with Article 45 paragraph (1) of the RUU PDP with efforts to realize administrative sanctions in Article 50 paragraph (1) RUU PDP. Furthermore, making DPO a profession with clear systematics according to the formulation of the addition of Article 45A to the RUU PDP which discusses the provisions for the formation of ethical discipline, code of ethics along with the setting of a code of ethics commission to oversee the performance of DPOs, standardization of standards to train the skills and skills of the DPO profession, and association as a statutory mandate to make efforts to protect personal data. With the formulation of the DPO professional regulation, it can also provide a role for DPOs in carrying out the function of protecting personal data and providing more trust for digital financial users to conduct transactions in the digital era in Indonesia. 


\section{References}

Agren, K., Bjelkmar, P., \& Allison, E. (2021). The use of anonymized and aggregated telecom mobility data by a public health agency during the COVID-19 pandemic: Learnings from both the operator and agency perspective. Data \& Policy, 3.

APPDI. (2021). Asosiasi Profesional Privasi Data Indonesia. Retrived from https://appdi.org.

Astutik, Y, \& Hastuti, R. K. (2020). Transaksi Digital Sampai E-Commerce Melesat Di Era Pandemi, CNBC Indonesia, Retrived March 18, 2021 from https://www.cnbcindonesia.com/tech/20200825151913-37-181854/transaksi-digitalsampai-e-commerce-melesat-di-era-pandemi.

CNN Indonesia. (2020a). Bos Tokopedia Bicara Soal Pencurian 91 Juta Data Pengguna. Retrived March 18, 2021 from https://www.cnnindonesia.com/teknologi/20200512123606-185-502440/bostokopedia-bicara-soal-pencurian-91-juta-data-pengguna.

CNN Indonesia. (2020b). Kronologi Lengkap 91 Juta Akun Tokopedia Bocor Dan Dijual. Retrived March 18, 2021 from https://www.cnnindonesia.com/teknologi/20200503153210-185-499553/kronologilengkap-91-juta-akun-tokopedia-bocor-dan-dijual.

Divi, M. (2020, June15). Delivery: First Sanction in Spain for Not Having a Data Protection Officer. $H \& A$. Retrived March 20, 2021 from https://www.hyaip.com/en/news/glovodelivery-first-sanction-in-spain-for-not-having-a-data-protection-officer/.

Hutchinson, C. S., \& Treščáková, D. (2021). The challenges of personalized pricing to competition and personal data protection law. European Competition Journal, 1-24. https://doi.org/10.1080/17441056.2021.1936400.

Kaya, M. (2020). The New Paradigm of Data Protection Law: The Principle of Accountability. Istanbul Law Review, 78(4), 1859-1897.

DOI:10.26650/mecmua.2020.78.4.0005.

Kurien, K. L., \& Chikkamannur, A. (2019). Detection and prediction of credit card fraud transactions using machine learning. International Journal Of Engineering Sciences \& Research Technolog.

Malik, A. (2020, Nov 19). Transaksi Uang Elektronik Hingga Oktober 2020 Tembus Rp 163 Triliun, Lampaui 2019. Bareksa. Retrived March 18, 2021 from https://www.bareksa.com/berita/reksa-dana/2020-11-19/transaksi-uang-elektronikhingga-oktober-2020-tembus-rp163-triliun-lampaui-2019.

Mulligan, S. P., Freeman, W. C., \& Linebaugh, C. D. (2019, March 25). Data protection law: An overview. In R45631. Congressional Research Service. Retrived from https://crsreports.congress.gov/product/pdf/R/R45631. 
Nikkel, B. (2020). Fintech forensics: Criminal investigation and digital evidence in financial technologies. Forensic Science International: Digital Investigation, 33, 200908. https://doi.org/10.1016/j.fsidi.2020.200908.

Sidharta, B. A. (2015). Etika dan Kode Etik Profesi Hukum. Veritas et Justitia, 1(1). Retrived from https://journal.unpar.ac.id/index.php/veritas/article/view/1423.

Sinaga, E. M. C., \& Putri, M. C. (2020). Formulasi Legislasi Perlindungan Data Pribadi dalam Revolusi Industri 4.0. Jurnal Rechts Vinding: Media Pembinaan Hukum Nasional, 9(2), 237. http://dx.doi.org/10.33331/rechtsvinding.v9i2.428.

Stephanie, C. (2021, January 1). 7 Kasus Kebocoran Data Yang Terjadi Sepanjang 2020. Kompas.Com. Retrived March 19, 2021 from https://tekno.kompas.com/read/2021/01/01/14260027/7-kasus-kebocoran-data-yangterjadi-sepanjang-2020?page $=$ all

Sugianto, Fajar. Kode Etik Profesi. (2017). Program Studi Magister Profesi Psikologi Fakultas Psikologi Universitas 17 Agustus 1945 Surabaya.

Wolford, B. (2018). Everything You Need to Know About the GDPR Data Protection Officer (DPO). Retrived from https://gdpr.eu/data-protection-officer/ 


\title{
EFFECTIVNESS OF WORK MOTIVATION AND ITS INFLUENCE ON WORK OUTCOMES
}

\author{
Philip R. Ivanov ${ }^{1}$ \\ Mariana N. Usheva ${ }^{2}$
}

\begin{abstract}
The current paper is aimed at investigating and proving the link between motivation and various outcomes such as - a propensity for staying in the company; psychological tension among employees; pride of working in the current company; engagement; work satisfaction; initiative in work. Our main goal is to prove the direct link between, the so-called "match factor" and the work outcomes. The study was held in the form of a survey among two groups, totalling 596 respondents in various sectors of the economy. And the results were tested with regression analysis for proving a significant influence of the match factor. Based on the result testing, we concluded that there is a direct link between motivation and work outcomes.
\end{abstract}

Keywords: Motivation, work outcomes, workplace motivation

JEL Codes: M12, M54

\section{Introduction}

Ever since human behaviour started to interest scholars, motivation was the main topic. The problems of motivation are ever actualizing in numerous aspects, one of which is motivating people in their workplace. The tremendous interest in motivation in both social and work aspects has led to the formulation of numerous views when defining the term. For example, Latham and Pinder (2005), describe motivation as a psychological process, resultant from the interaction of the human and the environment (p. 486). This view is part of the theoretical current, accepting motivation as a constant interaction between humans and the environment. Alternately, Deckers (2010) describes motivation as a process of initiating, directing and maintaining goal-directed behaviour (p. 6). Hence, motivation can be a process, directing one's behaviour in a certain way, which could guarantee a given desired outcome. Pinder (2008), describes the motivation in the work process as a set of energetical powers, initiating the work behaviour and determining its power, direction, intensity and duration (p. 13). Therefore, motivation in the workplace could cause behaviour, which eventually could lead employees in a certain direction. The goal of human resource managers is to set the circumstances in such a way, that the directed behaviour is in favour of the company. Another way of viewing motivation is as a constant chase of certain goals, which are a result of a given physiological or psychological needs. Motivation as well can be described as a process of taking a voluntary decision to undertake a particular purposeful action or inaction under given circumstances. It is subjective, runs within an individual's mind, and is reduced to the personal appraisal of all the impacts on him/her, of the signals sent by the economic, organizational and social environment of the enterprise (Dimitrova \& Sotirova, p. 168).

\footnotetext{
${ }^{1}$ Department of Management and Marketing, Faculty of Economics, SWU "Neofit Rilski” Blagoevgrad, PhD student, e-mail: filip.ivanov.1@abv.bg

ORCID iDhttps://orcid.org/0000-0002-5335-0317

${ }^{2}$ Department of Management and Marketing, Faculty of Economics, SWU "Neofit Rilski" Blagoevgrad, assoc. prof., PhD, e-mail: m.usheva@abv.bg

ORCID iDhttps://orcid.org/0000-0001-8626-2762
}

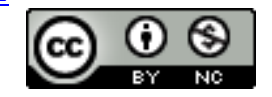

This work is licensed under a Creative Commons Attribution-Non Commercial 4.0 International License. 
Consequently, motivation is a vastly complex problem within managing people, which at the same time is of great importance. Ivanov and Usheva (2021a) combined the most popular views and defined motivation as directing psychological processes, built by various energetic powers, having the goal to affect behaviour in a way, determining the direction, intensity and persistence of an individual's behaviour (p. 98). There are many more views in the field, but further investigating on the matter is not necessary for the current paper.

Namely, the big importance of the current topic has led to tremendous interest in motivation among scholars. Many theories and theoretical currents are formulated through many years of work. In the further part of the paper, we will give examples of the most popular theories in motivation along with a brief intro into each of them. Later, we will give examples of a certain influence of motivation in work outcomes, which is namely our main goal in the current study.

Our aim in the paper is to investigate and provide proof of the influence of ineffective motivation in work on certain work outcomes. For doing so, we surveyed various organizations. The greater part of the respondents was a part of a railway company, located in Bulgaria. There were respondents from various kinds of companies, data of which will be provided below. For evaluation of motivation in work, we formulated a coefficient, which had the goal to describe the difference between employees' desires and their acquisitions in work. Hence, we were able to investigate the influence of motivation on the outcomes, that we chose to study. Therefore, our main hypothesis in the study is that there is a statistically significant influence of motivation on work outcomes.

\section{Motivational influences in workplace environment}

Many authors have proven the direct link between motivation and peoples' performance in their work (Latham, 2012). Therefore, human motivation could have a serious effect on the execution of labour. In the practical environment, motivation could be influenced by vastly diverse factors. Such as - personality traits (Bipp, 2010, p. 29); autonomy support (Gillet at all, 2017, p. 1167); leadership empowerment (Zhang \& Bartol, 2010, p. 17); age and lifespan (Kanfer \& Ackerman, 2004, p. 455456), social interaction and cultural dependencies (Wood \& Bandura, 1989, p. 378-380), (Bandura, 2002, p. 280-282), (Roe et all, 2000, p. 675-677). Based on the last, Ivanov and Usheva (2021b), concluded that many of the factors influencing motivation can have a great influence on work outcomes, namely because of the strong connection between work motivation and work outcomes (p. 86). Therefore, bearing in mind, the above mentioned and empirically proven factors, influencing motivation, we can state, that everything linked with motivation is of great importance for human management practice.

To underline the vast interest in the field of motivation theory and research, we would like to pay attention to the different motivational theories, formulated in the past. Of course, this will be only a brief intro to the most influential theories, which has had great influence not only to the theory of Behavioural psychology but as well on the theory of Management.

Maybe the most influential and popular view of motivation is the theory of Maslow. Maslow (1954) defined the whole process of motivation as a constantly chasing of the fulfilment of certain needs. He groups the needs into five categories, which are hierarchal ordered and the only possible way for an individual to go to a higher level is to fulfil his "lower needs". This is known as a frustration-progression process. For the time being, Maslow's theory of motivation had his applications.

Based on his critic of the hierarchy of motivation, Alderfer (1969) formulated his theory. He acknowledges three groups of needs - defines three groups of needs - Existence; Relatedness; Growth (pp. 142-175). The most important aspect of his theory is the frustration-regression process, which means, that the individual will try to fulfil his most concrete needs. This, in often cases, means to leave the "higher needs" to fulfil the needs, which at this moment are more concrete.

Another author, which had a great influence on the theory of motivation is Herzberg (1968). $\mathrm{He}$ is one of the first authors, which researched within a work environment. Based on his famous study among engineers and accountants, he formulated his theory and stated that motivation is a 
process of constant synergy between motivational and hygiene factors. According to his work, hygiene factors are only a reason for a lack of dissatisfaction and cannot lead to satisfaction. Vice versa, motivational factors are the only expedient path for work satisfaction.

The work of McClelland influenced the field of motivational theory in a significant way as well. The basic statement in his theory is that the levels of motivation are highly dependent on the urge to achieve. Or as the author states - people with the high necessity for achievement get faster to promotions, because of the active seeking of ways for working better. Companies, in which there are many such individuals, grow faster. Countries, in which there are many such fast-growing companies, usually, achieve above the average economic growth (MacClelland, 2013). Consequently, achievement motivation among workers could lead to higher diligence in work, higher engagement and overall better results.

Not all scholars view motivation as the process of ever actualizing needs which the individual need to fulfil to get satisfaction. Some such as Lawler and Porter (1967); Locke, Latham and Erez (1988); Latham and Pinder (2005); Oldham and Hackman (1981); etc. Describe motivation as a constant interaction between the individual and the environment. Nonetheless, further investigation in all theories is not necessary for the current study.

Work outcomes could be highly influenced by the application of the motivators in the aspect of the previously mentioned views of motivation. The results of the annual survey of the organization "World at work", proved, that in the modern world, the most common practically applied form of motivation is the material stimulation, based on the scheme, known as "Pay for performance" (World at work, 2019, p. 12). Although the data provided is from 2019, this tendency is maintained through 2020 and the beginning of 2021. The scheme "Pay for performance", can be described as paying more for better performance. Hence, there is a linear correlation, in this simulation model, between performance and material stimulations in work. Nonetheless, ever since the work of Maslow and especially Herzberg, it has been acknowledged that material stimulation is not a source of work satisfaction among a certain group of employees. Some authors go even further and state that material stimulation could suppress human motivation in a significant way (Deci \& Ryan, 2000, p. 229); (Gagne \& Deci, 2005). Furthermore, scholars have proven that most of the positive work outcomes are positively correlated with intrinsic motivation and negatively related to negative work outcomes. Controversially, external motivation is not associated at all or negatively associated with positive work outcomes and positively associated with negative work outcomes (Kuvaas, Buch, Weibel, Dysvik \& Nerstad, 2017, p. 251). Hence, material stimulation can have an insignificant work improvement or even could lead to a significant decline in work performance. Consequently, workrelated motivational schemes should acknowledge the wide variety of human needs, material and non-material. In addition, practitioners must apply such forms of stimulation, which have the potential to lead to a higher state of human development and skill improvement.

Pay is a vital part of human motivation. Yet, as we stated, it cannot be the only source of human motivation. There are certain lines of work, where schemes, that include pay for performance incentives are vital for better performance of employees. For example, Kuvaas, Buch, Gagne and Dysvik, (2016) conducted a study among salespeople, concluded that pay for performance schemes are positively related to self-reported work effort and negatively related to turnover intentions among workers (p. 672). Hence, among salespeople pay can play a vital role while striving for better work results. Moreover, in certain conditions, pay for performance is expected to positively influence positive work outcomes and negatively influence negative outcomes.

Additionally, there is proof for the controversially. For example, Olafsen, Deci and Halvari (2017) state, that people are not motivated by the results, which are a consequence of the taken action and the good execution of the task. They tend to take actions, which are interesting and have more deep meaning for them (p. 179). Hence, in some conditions pay could not lead to higher effort. Moreover, Deci and Ryan (2000) report a meta-analytic study, examining the influence of material rewards on intrinsic motivation. The study proves that not only all monetary rewards but also all tangible rewards, significantly diminish intrinsic motivation (p. 234). Therefore, payment must be 
applied very careful while motivating employees. While it comes to intrinsic motivation, which is often described as more stable within the workplace, leaders have to use monetary stimulation, only in a certain way, while leaving the possibilities of higher human development.

Leadership is one of the most influential aspects in practice, which can have a significant role and form certain motivational paradigms in the workplace. It can affect the values in work in such a way that they could influence significantly the requirements in the motivational aspect of the employees. In line with this, Van Tuin, Schaufeli and Van den Broeck (2021), conducted a study providing evidence that engaging leadership can positively affect intrinsic values, through need satisfaction, as well as it could result in higher engagement in work (p. 15). Consequently, leadership can have a serious effect on motivation, when it comes to values forming and need satisfaction in the workplace. In line with the work of Van Tuin et. all (2021), Van Tuin, Schaufeli and Van Rhenen (2020), stated that engaging leadership is associated with work motivation and engagement through needs satisfaction and autonomy satisfaction in particular because autonomy fosters positive outcomes and decreases adverse outcomes (p. 19). Hence, leaders could play a vital role in the motivation of the personnel. Leaders can contribute significantly to better results through better motivational practices, but they can also diminish almost every good effort of workers if they apply unsuitable forms of motivation to practice. Moreover, the managers are the ones who need to investigate and implement the most effective forms of motivation. Therefore, it can be concluded, that the goal of the manager is to motivate the employees so that they perform the work in the best way to achieve the goals of the company. (Filipova, 2011, p. 137). In addition, Yaneva claims, that an integral part of the strategic decision-making process in the organization is the study of the indicators related to the employees' development and motivation (2021, p. 170).

Feedback is a part of the work environment that can have a significant influence on the motivation of the personnel. Providing certain levels of feedback in work could diminish or flourish human performance. For example, in a meta-analytic study Fong, Patall, Vasquez and Srauberg (2019), concluded that in numerous of the empirical studies they have examined, the negative feedback undermines intrinsic motivation in a significant way (p. 124). Hence, once the negative feedback is applied in the workplace, it could lead to a serious diminish of the intrinsic motivation, and consequently to less effort in work in the future. Furthermore, Belschak and Hartdog (2009), concluded that positive feedback, publicly or privately given, will lead to positive effects on the emotional state of the workers. Controversially, negative feedback will lead to a negative emotional state, even more so, if given publicly. Therefore, feedback as a part of the work environment can have a significant influence on human motivation and accordingly on work performance. Moreover, Dimitrova (2020) argues, that positions with higher quality that provide feedback, opportunities for self-control and learning are a good opportunity to strengthen the internal motivation of employees.

Human motivation is a very complex process, influenced by a wide variety of factors within the work environment. As we examined above, motivation can be the source either of greater work effort and better overall work results, or a hindrance of such. We concluded that the factors, which influence motivation, have the power also to influence work outcomes in the process of applying labour force in the company. Therefore, we formulated our study from the foundation of these postulates. As we will examine in the further sections of the current article, motivation can have a significant influence on the work outcomes, which we examined.

\section{Methodology}

Our study was held in two different forms, examining two different groups of respondents. In the first part respondents were part of a wide variety of industries (manufacturing industry, transport and logistics, energy, trade and commerce, IT, etc.) $(\mathrm{n} 1=145)$. The second part of the respondents is part of a governmentally owned railway company ( $\mathrm{n} 2=451)$. The type of industries and the actual respondents were chosen with a random selection. The main goal for which, was to provide enough vastly diverse results when examining the motivation in the workplace. The number of the 
respondents has been calculated from the total fully and properly filled surveys for each group separately. The research was held for two months in the year 2020.

In our study, we examined motivation by selecting numerous motivators in the workplace environment. For a better understanding of the motivation in the companies at hand, we divided the motivators into 6 modules, as follow - 1. Work Environment (WE); 2. Remuneration (R); 3. Safety (S); 4. Personal development (PD); 5. Affiliation and social aspects (ASP); 6. Respect and selfrespect Interest and challenge, autonomy and leadership (RS; IC; AL).

In the first part of the survey, we asked our respondents for the most subjectively valuable motivators for them. We achieved this using a five-point Likert scale, allowing us to analyse the results quantitatively. Hence, we were able to calculate the average attestation for each of the modules. In the second part of the survey, we asked respondents to report the actual application in their work of the formally mentioned modules. Lastly, we compared the results, formulating a coefficient, which we called "Match factor", which had the goal to describe the actual match between the preferred forms of motivation and the applied in the workplace. The formulation of the formerly mentioned coefficient is fully an idea of the author and does not profess full and undisputable clarity and unconditional application in motivational theory. The formulation of the coefficient is an attempt to attestation the effectiveness of the motivation in our response groups. Calculation of the "Match factor" is made by dividing the total average from the results of the subjective attestation for the importance of a given element of the formulated module and its actual application in the work environment. These calculations were performed for each of the respondents, allowing us to achieve also a regression analyses between the coefficient for the effectiveness of motivation and the work outcomes. The formulation and calculation of the match factor led to the conclusion that if the match factor is with value 1 , there is a perfect match between the preferred and applied motivational elements. Consequently, if the match factor is greater than 1, there is a mismatch in favour of more preferred elements and less applied. Controversially, if the match factor is less than 1, there is a mismatch in favour of more applied elements than preferred.

The third part of our survey had the goal to evaluate in subjective means the opinion of the workers regarding certain work outcomes, we formulated for the study. Namely, they are - the propensity for staying in the company (PSW); psychological tension among employees (PSYTENS); pride of working in the current company (PRIDE); engagement (ENGAGE); work satisfaction (SATISF); initiative in work (INIT). Each of the outcomes was evaluated by asking the respondents, questions and inviting them to evaluate each with a scale. The questions for each outcome are as follow:

- Propensity of staying at work - If it is up to you, you will work in your current company after 5 years.

- Psychological tension - Do you have the feeling that you are working in a psychologically tense environment.

- Pride of working in the company: It is a pride for you to work in the current company.

- Engagement - To what degree do you feel engaged with the work and overall results of your company.

- Satisfaction - Please evaluate your overall satisfaction from work!

- Initiative - Please express your readiness for engaging in a task and overall initiative!

After the evaluation of the work outcomes, we conducted a regression and correlational analysis to find any statistically significant influence of the match factor in the aspect of motivation in the workplace and the formally mentioned work outcomes.

Hence, we formulate the following hypothesizes:

Hypothesis 1: The match factor is influencing the propensity of staying in the company.

Hypothesis 2: The match factor is influencing the psychological tension in the company.

Hypothesis 3: The match factor is influencing the pride of working in the company.

Hypothesis 4: The match factor is influencing engagement in work. 
Hypothesis 5: The match factor is influencing work satisfaction.

Hypothesis 6: The match factor is influencing work satisfaction.

For testing the hypothesizes, we conducted a simple regression analysis, using Microsoft Excel. In our analysis, the independent variable is the match factor and our dependent variables are the work outcomes. For better clarity and better results, we conducted regression analysis separately for each work outcome.

\section{Results and discussion}

We conducted the analyses in the two groups separately. We provide the results in tables as follows below.

Table 1: Regression results of the match factor and work outcomes in first group

\begin{tabular}{|l|l|l|r|r|r|r|}
\hline $\begin{array}{c}\text { Significants } \\
\text { and } \\
\text { correlation }\end{array}$ & PSW & PSYTENS & \multicolumn{1}{c|}{ PRIDE } & \multicolumn{1}{c|}{ ENGAGE } & \multicolumn{1}{c|}{ SATISF } & \multicolumn{1}{c|}{ INIT } \\
\hline $\mathbf{P}$ & 0,0007 & 0,12 & $8,53471 \mathrm{E}-05$ & 0,65 & 0.0003 & 0.05 \\
\hline $\mathbf{r}$ & $-0,31$ & 0,02 & $-0,13$ & 0,0019 & -0.11 & -0.03 \\
\hline
\end{tabular}

Source: Own research

The results shown in Table 1 are relevant to the group which had respondents with various employment. As we can see first-hand, we can either prove or reject the hypothesizes. As it is known from the statistical science, if the P-value (statistical significands) is higher than 0.05 , we accept the null hypothesis, which states that there is no significant influence by the dependent invariable, in our case the match factor, and the depended variable, in our case the work outcomes.

Therefore, in the first group, we can accept our first hypothesis because the results proved a statistically significant influence by the match factor and the propensity of staying in work. As we can see by the correlation coefficient the influence is negative. Hence, with the increasing mismatch in motivation within our first group of respondents, the propensity of staying in the company decreases. It wasn't found any significant influence from the match factor on the psychological tension. Therefore, we reject our second hypothesis in the first group of respondents. Based on the results, we can accept our third hypothesis, because there was a proven statistically significant influence by the match factor on the pride of working for the company. We reject our fourth hypothesis, as there was no proven statistically significant influence by the match factor on engagement in our first group. We accept our fifth and sixth hypotheses, as we proved a statistically significant influence by the match factor on satisfaction from work and initiative. As we can see, in both cases the correlational coefficient describes a negative connection. Hence, with the increase of the mismatch in the motivation in our first group, there will be an expected decline in satisfaction and initiative.

There were some differences within the results in the two groups of respondents. We represent the results for the group of respondents, employed in a governmentally owned railway company in Table 2 below.

Table 2: Regression results of the match factor and work outcomes in second group, employed in governmentally owned railway company

\begin{tabular}{|l|c|c|r|r|r|r|}
\hline $\begin{array}{c}\text { Significands } \\
\text { and } \\
\text { correlation }\end{array}$ & PSW & $\begin{array}{c}\text { PSYTEN } \\
\text { S }\end{array}$ & PRIDE & ENGAGE & \multicolumn{1}{c|}{ SATISF } & \multicolumn{1}{c|}{ INIT } \\
\hline $\mathbf{P}$ & $1,1708 \mathrm{E}-14$ & $1,33 \mathrm{E}-08$ & $2,2043 \mathrm{E}-08$ & $3,93568 \mathrm{E}-07$ & $4,1092 \mathrm{E}-12$ & $6,7047 \mathrm{E}-06$ \\
\hline $\mathbf{r}$ & $-0,13$ & 0,07 & $-0,08$ & $-0,06$ & -0.11 & -0.03 \\
\hline
\end{tabular}

Source: Own research 
As we can see in Table 2, we can accept Hypothesis 1 to 6 , as there is a statistically significant influence of the match factor on the examined work outcomes. As we can see there is a negative connection between the match factor and propensity of staying in work, pride, engagement, satisfaction and initiative. Therefore, we can conclude that as the mismatch in motivation in our second group increases, the formally mentioned work outcomes, decline. There is a positive connection between the match factor and the psychological tension. We did expect a positive relationship with the psychological tension. Hence, with the increase of the mismatch in work motivation, the sensation of psychological tension in work increases.

Except for the formally mentioned influences by the match factor on the various work outcomes, Ivanov and Usheva (2021b), provided proof of high interdependency between the examined work outcomes. They proved the strong connection between the work outcomes themselves and linking them with one another. Hence, we can conclude that except for the influence of the match factor, the work outcomes could be influenced by the rest of the outcomes described above.

\section{Conclusion}

Motivation is an exceptionally important concept within the management of human resources. There are many views and hence, many different definitions of the term. Nonetheless, most of the authors describe motivation as a set of energetic powers, having the goal to affect behaviour in a way, determining the direction, intensity and persistence of an individual's behaviour. Therefore, motivation should be accepted as an externally for the individual process, which leads him to a certain direction. Motivation should be accepted, as well as, an internally initiated process, coming from the internally initiated personal goals of the individual.

The high interest in motivation among scholars is justified by the high importance on the matter not only in human resource management but as well in organizational psychology and other disciplines. The reasons for the chosen direction of the behaviour can have a significant influence on work performance in almost every industry. A better understanding of motivation can be the source of better motivational programs, better and greater work abilities, and therefore, better work results in general. Consequently, empirical studies, as the one formulated for the current research are of high importance for the practical application of motivational programs in various industries.

Based on the results of our research, we can conclude that there is a ratter low motivational effectiveness through the two groups examined. Moreover, we can state that there is a statistically significant influence by the match factor (motivational effectiveness) on almost every work outcome in the first group and every outcome from our second group of respondents. Hence, almost fully proving our formulated hypothesis in the first group, and fully proving our hypothesis in the second group of respondents. Moreover, as the influence is significant it is negative within the positive work outcomes and positive with the negative work outcomes, such as the psychological tension. Therefore, we can conclude that the ineffectiveness in human motivation can lead to lower levels in the positive work outcomes and higher levels in the negative work outcomes. Eventually, this could lead to higher stress levels, lower engagement with work, turnover intentions, less pride from working for the company, lesser satisfaction and worse initiative from workers. This tendency could eventually lead to worse overall work results and consequently, to worse competitiveness levels. This will be worse in industries, which are highly dependent on the better work of their employees. Moreover, in the current economic conditions, such industries are the majority. Therefore, managers must look into the motivation of their employees, and provide a dynamical synergy between material and nonmaterial stimulation, and at the same time take into account the employee's motivational requirements. 


\section{References}

Alderfer, C. (1969). An empirical test of a new theory of human needs. Organizational behaviour \& human performance, 4(2), 142-175. https://doi.org/10.1016/0030-5073(69)90004-X.

Bandura, A. (2002). Social cognitive theory in cultural context. Applied psychology: An international review, 51(2), 269-290. https://doi.org/10.1111/1464-0597.00092.

Belschak, F., \& Den Hartog, D. (2009). Consequences of positive and negative feedback: The impact on emotions and extra-role behaviours. Applied psychology: An international Review, 58(2), 274-303. https://doi.org/10.1111/j.1464-0597.2008.00336.x.

Bipp, T. (2010). What people want from their jobs? The big five, core self-evaluations and work motivation. International journal of selection and assessment, 18, 28-39. https://doi.org/10.1111/j.1468-2389.2010.00486.x.

Deci, E., \& Ryan, R. (2000). The "What" and "Why" of goal pursuits: Human needs and the selfdetermination of behaviour. Psychological inquiry, 11(4), 227-268. https://doi.org/10.1207/S15327965PLI1104_01.

Deckers, L. (2010), Motivation: Biological, psychological, and environmental. Boston, MA, Allyn \& Bacon.

Dimitrova, M. (2021). Working conditions - a factor for retaining and attracting highly qualified human capital. Leadership, Society, Strategic Visions, 147-164. Retrieved from http://ojs.nbu.bg/ojs/index.php/LSSV/article/view/460.

Dimitrova, R. \& Sotirova, A. (2020). Human resource management within the context of innovational development of the enterprise. In: Management - Tourism - Culture, Studies and Reflections on Tourism Management, Ignatianum University Press, Kraków, pp 161174, ISBN 978-83-7614-468-9.

Filipova, M. (2011). Functional Special Feature in Management of the Tourism Company. SWU Press, Blagoevgrad.

Fong C., Patall, E., Vasquez, A., \& Stauberg, S. (2019). A meta-analysis of negative feedback on intrinsic motivation. Educational psychology review 31, 121-162. https://doi.org/10.1007/s10648-018-9446-6.

Gagne, M., \& Deci, E. (2005). Self-determination theory and work motivation. Journal of Organizational behaviour, 26(4), 331-362. https://doi.org/10.1002/job.322.

Gillet, N., Fouquereau, E., Vallerand, R. J., Abraham, J., \& Colombat, P. (2018). The role of workers' motivational profiles in affective and organizational factors. Journal of happiness studies, 19(4), 1151-1174. https://doi.org/10.1007/s10902-017-9867-9.

Herzberg, F. (1968). One more time: How do we motivate employees? Harvard Business Review January-February, 53-62.

Ivanov, P., \& Usheva, M. (2021a). Influence of the hierarchy positon and education degree on the preferences of motivators in the modern enterprise. Economics and Management 18(1), 96108. doi: 10.37708/em.swu.v18i1.8. 
Ivanov, P., \& Usheva, M. (2021b). Workplace outcomes, the example of Bulgarian corporations. Ekonomicko-manazerske spektrum, 15(1), 84-96. DOI: dx.doi.org/10.26552/ems.2021.1.8496.

Kanfer, R., \& Ackerman, P. (2004). Aging, Adult Development, and Work Motivation. Academy of Management Review, 29(3), 440-458. https://doi.org/10.5465/amr.2004.13670969.

Kuvaas B., Buch R., Gagne M., \& Dysvik A., Do you get what you pay for? Sales incentives and implications for motivation and changes in turnover intention and work effort. Motivation and emotions, 40, 667-680. https://doi.org/10.1007/s11031-016-9574-6.

Kuvaas, B., Buch, R., Weibel, A., Dysvik, A., \& Nerstad, C. (2017). Do intrinsic and extrinsic motivation relate differently to employee outcomes? Journal of Economic Psychology, 61, 244-258. https://doi.org/10.1016/j.joep.2017.05.004.

Latham, G. (2012) Work motivation: History, theory, research and practice. Thousand Oaks, CA: Page Publications, 82-100.

Latham, G., \& Pinder, G. (2005). Work motivation theory and research at the dawn of the TwentyFirst Century. Annual Review Psychology, 56(1), 485-516. DOI: 10.1146/annurev.psych.55.090902.142105.

Lawler, E., \& Porter, L. (1967). The Effect of performance on job satisfaction. Industrial Relations, 7(1), 20-28. https://doi.org/10.1111/j.1468-232X.1967.tb01060.x.

Locke, E., Latham, G., \& Erez, M. (1988) The determinants of goal commitment. The Academy of Management review, 13(1), 23-39. https://doi.org/10.2307/258352.

McClelland, D. C. (2013). That urge to achieve. Readings and Exercises in Organizational Behavior, 70-76.

Maslow, A. (1954). Motivation and personality. Harper \& Row publishers, London.

Olafsen, A., Deci, E., \& Halvari, H. (2017). Basic psychological needs and work motivation: A longitudinal test of directionality. Motivation and emotion 42, 178-189.

DOI:10.1007/S11031-017-9646-2.

Oldham, G., \& Hackman, J. (1981). Relationships Between Organizational Structure and Employee Reactions: Comparing Alternative Frameworks. Administrative science quarterly, 26(1), 6683. Retrieved from https://www.jstor.org/stable/2392600?origin=JSTOR-pdf\&seq=1.

Pinder, C. (2008). Work motivation in organizational behaviour, New York, Psychology press.

Roe, R., Zinovieva, I., Dienes, E., \& Ten Horn, L., A. (2000). A comparison of work motivation in Bulgaria, Hungary and the Netherlands: Test of a model. Applied Psychology: An international review, 49(4), 658-687. https://doi.org/10.1111/1464-0597.00039.

Van Tuin L., Schafeli W., \& Van Rhenen W. (2020). The satisfaction and frustration of basic psychological needs in engaging leadership. Journal of leadership studies, 14(2), 6-23. https://doi.org/10.1002/jls.21695. 
Van Tuin, L., Schaufeli, W., \& Van den Broeck, A. (2021). Engaging leadership: Enhancing work engagement through intrinsic values and need satisfaction. Human Resource Development Quarterly, 1-23. DOI: 10.1002/hrdq.21430.

Wood, R., \& Bandura, A. (1989). Social Cognitive theory of organizational management. Academy of management review, 14(3), 361-384. https://doi.org/10.5465/amr.1989.4279067.

World at work. (2019). Inventory of total rewards program \& practices. Retrieved from https://worldatwork.org/media/Survey/Survey\%20BriefTotal\%20Rewards\%20Inventory\%202019.pdf

Yaneva, D. (2021). Strategic decisions in the management of the marketing activity of the enterprise. University Publishing House "N. Rilski”, Blagoevgrad.

Zhang, X., \& Bartol, K. (2010). Linking empowering leadership and employee creativity: The influence of psychological empowerment, intrinsic motivation, and creative process engagement. The academy of management review, 53(1), 107-12.

https://www.jstor.org/stable/25684309. 


\title{
CAPITAL FLOWS AND ECONOMIC GROWTH. EVIDENCE FROM VIETNAM
}

\author{
YEN HAI NGUYEN ${ }^{1}$ \\ PHAM XUAN HUNG ${ }^{2}$
}

\begin{abstract}
The study examines the impact of foreign capital flows on economic growth in Vietnam over the period 1989-2019 using autoregressive distributed lag (ARDL). The findings indicate that there exists a long-run relationship between economic growth and foreign capital flows. Foreign direct investment stimulates economic growth both directly and indirectly since the findings indicate that in both the short and long run, foreign direct investment has significantly positive effects on economic growth. Foreign direct investment can also indirectly affect growth through appreciation of human capital due to the existence of a bi-directional Granger causality relationship between human capital and foreign direct investment. Our findings suggest that foreign direct investment and human capital are complementary to improving economic growth and Vietnam should promote foreign direct investment with enhancing human capital accumulation. External debt, however, has an insignificant impact on growth and the impact of foreign aid is also negative. Vietnam, therefore should not rely on external debt in the long run and allocate the effectiveness of foreign aid to achieve the optimal target.
\end{abstract}

Keywords: foreign capital flows, economic growth, ARDL, Vietnam

JEL Codes: A10, E22, F43

\section{Introduction}

Developing and less developed nations have some traits in common as lower per capita income and inadequate domestic resources to finance public investments for economic growth. Low savings and budget deficits lead to a significant financing gap then hinders public investment. Therefore, closing the saving investment gaps is one of the targets for sustainable development of developing countries and Vietnam is no exception. Most developing countries have received a large number of foreign capital inflows from some sources, namely foreign direct investment (FDI), foreign aid as official development assistance, and external debt from developed nations to fill the gap of inadequate capital.

As one of the leading investment destinations in Southeast Asia, Vietnam has attracted a large amount of FDI flows in recent years, based on competitive advantages of geography, unexplored sectors, a growing consumer market and labour force. The Vietnam economy has benefited immensely from significant foreign direct investment flows for more than three decades with the high contribution of FDI flows to economic growth. During the last two decades, it has witnessed the rapid growth rate of Vietnam, and one of the significant determinants of its miracle growth rate is the large inflows of foreign capital from international organizations. According to the General Statistics Office (2019), during the period from 1991

${ }^{1}$ Lecturer, University of Economics, Hue University, 99 Ho Dac Di street, Hue City 49000, Vietnam, e-mail: nguyenhaiyen@hueuni.edu.vn

ORCID IDhttps://orcid.org/0000-0003-2379-8388

${ }^{2}$ Senior Lecturer, University of Economics, Hue University, 99 Ho Dac Di street, Hue City 49000, Vietnam, email: pxhung@hueuni.edu.vn

\section{ORCID iDhttps://orcid.org/0000-0001-9817-3863}

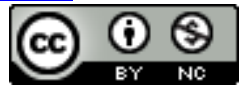

This work is licensed under a Creative Commons Attribution-Non Commercial 4.0 International License. 
to 2019 , the estimated average of FDI flows in Vietnam is 6.88 US\$ billion, hitting a record in 2019 with US $\$ 20.38$ billion. Figure 1 illustrates the relation between GDP growth and foreign direct investment and foreign aid (\% of GDP) in Vietnam over the period 1989-2019. The first group has a strong positive association between GDP growth and FDI (\% of GDP). By contrast, the second groups between GDP growth and AID (\% of GDP) seem to be relatively flat.

Figure 1. FDI, AID as a share of GDP
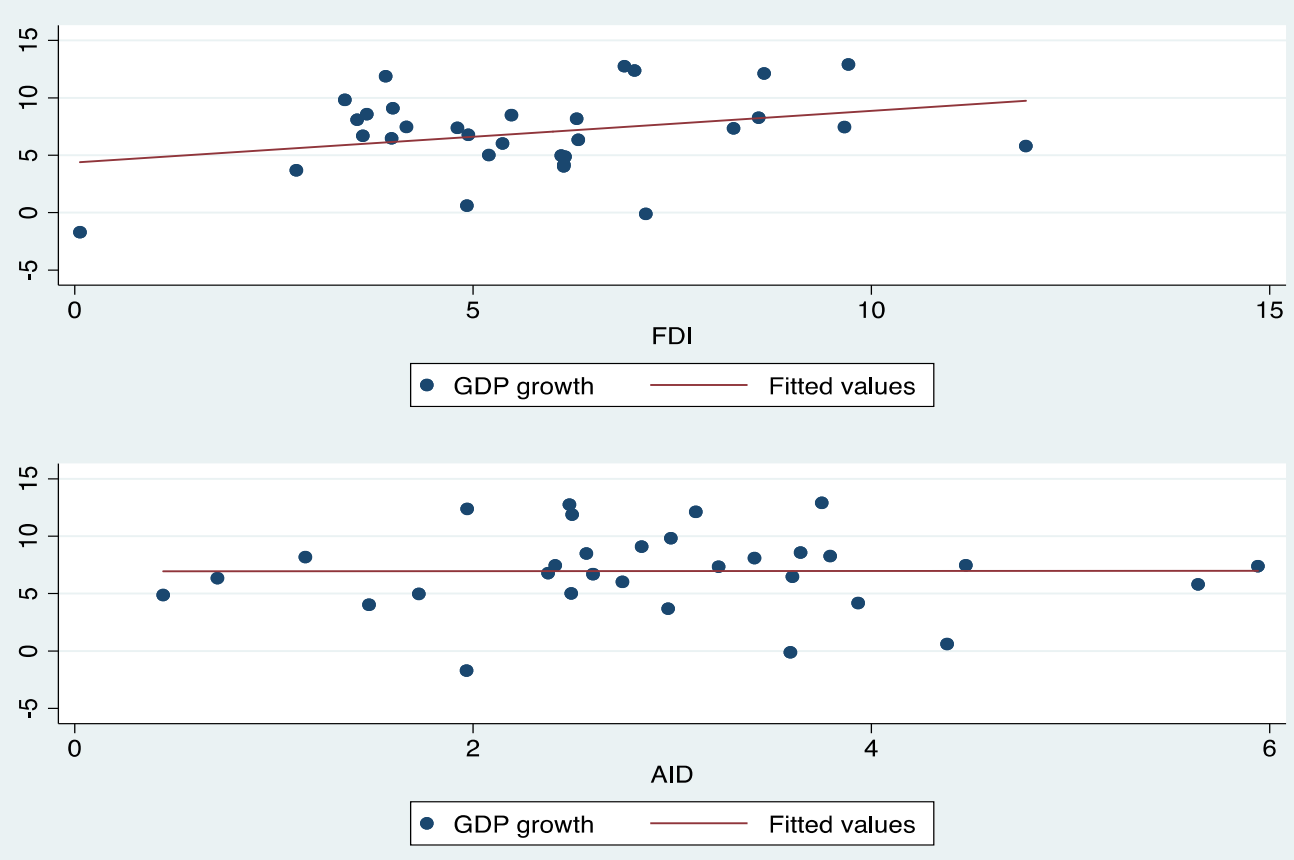

Source: Author's calculations based on World Development Indicators and Penn World Table 10.0

In comparison with other international capital flows, the dominant contributor to economic growth is FDI flows and followed by foreign aid which seems to be a flat line. Foreign capital flows, therefore, have received substantial attention in recent years among academics and policymakers in Vietnam. Besides, human capital is considered to be an important pillar of economic growth (Mankiw, Romer, \& Weil, 1992), developing countries hence facilitate the development of human capital through attracting foreign capital flows due to their limitations about education and social welfare, in the belief that foreign capital flows can increase human capital accumulation in host countries through growth effect of foreign flows. The critical role of human capital on the determinant of economic growth is depicted in Figure 2, which show the association between GDP growth, FDI and human capital for Vietnam in the period 19892019. As for the GDP growth and human capital, the relationship seems to be relatively flat. By contrast, the second group between FDI share of GDP and human capital have a strong positive relationship. 
Figure 2. GDP growth, FDI and human capital in Vietnam
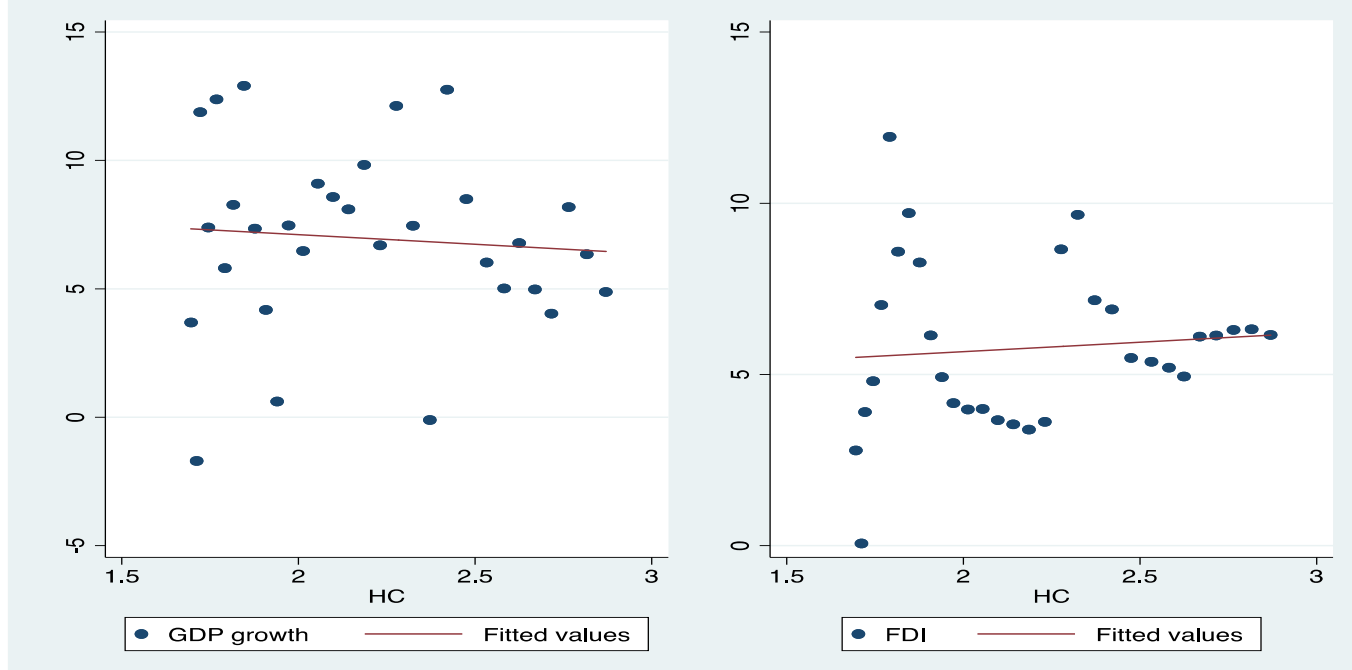

Source: Author's calculations based on World Development Indicators and Penn World Table 10.0

Vietnam has received substantial capital flows and has experienced impressive economic growth during recent years. However, Vietnam has still faced significant challenges to achieve the sustainable growth target by keeping a high level of growth rate, increasing income per capita and reducing the extreme poverty rate. Rare studies examine the link between foreign capital flow and economic growth in Vietnam, and others focus on the relationship between FDI and economic growth in Vietnam with mixed results. Nguyen (2016) investigates the relationship between international capital flows including foreign direct investment FDI, foreign aid ODA and economic growth during the period 2007Q1- 2015Q3 by applying ARDL methodology. The results show that FDI has a positive impact in the shortrun but weak effect on long-run economic growth while ODA is a significant positive effect in the long run. By applying Johansen (1988) methodology to investigate the long-run relationship between FDI, ODA, trade openness and economic growth in Vietnam from 19902014, Nguyen and Pham (2016) reveal that FDI has an insignificantly impact on economic growth while ODA has a significant positive effect on economic growth. Therefore, the relationship between foreign capital inflows and economic growth remains unclear in Vietnam.

The key issue addressed by this paper is whether an immense increase in capital flows has promoted economic growth. This question is still subject to examination of empirical research. Our purpose is to examine the differential impact of the various capital flows, including FDI, foreign aid, and external debt on economic growth in Vietnam. Thus, this study contributes to the literature in two ways. First, to examine the impact of foreign capital flows such as foreign direct investment, foreign aid, external debt on economic growth in Vietnam given the extensive argument above. Secondly, we deploy ARDL methodology with complete data on all the key variables of interest.

The rest of the paper is structured as follows: the second section examines the theoretical and empirical literature on foreign inflows and economic growth. This is followed by section three, where data resources and descriptive statistics are discussed. The fourth section presents the methodology and model specification, while section five highlights the empirical results and the final part provides concluding remarks and policy implications of the study.

\section{A theoretical and empirical literature review}

Foreign capital inflows refer to all sorts of capital from a country to another country, which could be namely foreign direct investment, foreign aid, external debt, technical assistant 
(Jhingan, 2010). The primary role of foreign capital flows in economic growth has been traced to neoclassical economics, which supported that international capital can boost domestic investment and spur economic growth for capital-scarce nations due to the allocative efficiency of capital. Liberalization allows to efficiently allocate capital from developed countries, where the return of capital is too low, to capital-scarce countries, where the return is too high (Fischer, 1997). The main points are that resource flows complement the domestic resources, close the investment financing gap and supplement domestic savings. Both neoclassical and endogenous growth theories agreed that foreign capital flows are the essential factor in accumulating capital and bringing technological progress in economic development. Foreign capital plays a vital role in economic growth for developing countries due to providing a level of technology transfer, increasing the skill levels in labor, and knowledge spillovers (Grossman \& Helpman, 1991; Mankiw et al., 1992). According to Todaro and Smith (2011), foreign capital flows are an essential factor in economic development growth since foreign capital can close the savinginvestment gap, as well as fill the technology and skills gap when host countries receive technology and training for skilled labor thorough process of learning by doing from developed countries. Therefore, foreign capital flows have been considered as one of the major conduits of technology transfer and closing the saving-investment gap because foreign capital consists of knowledge of new technologies and can be complemented capital for developing countries achieving economic growth targets.

On the other hand, there are some critics of these theories that the inflows of international capital have some detrimental effects on economic growth instead of promoting growth through crowding out domestic investments. Another analysis of the negative impact is associated with the collapse of the domestic firms in the case of competitive advantages of the multinational firms over domestic firms in terms of technology and managerial capabilities (Tang, Selvanathan, \& Selvanathan, 2008). In addition, Morrissey (2012) and Ndikumana and Sarr (2019) concluded that the contribution of international capital flows in African growth in terms of employment and welfare has been limited due to the absence of significant linkages among externalities, technology spillovers and domestic economy. They claimed that the consequences of African dependence on the international flows could expose the economy to risk in export instability and growth volatility.

Though many empirical studies have been conducted on the relationship between foreign capital flows and economic growth, there is no consensus on the real impact of its foreign inflows on developing countries. While some research showed the positive effect of some components of foreign capital flows such as FDI, foreign loans, foreign aid on economic growth, others showed that these factors of foreign capital have no significant positive effect on growth rate (Goh, Sam, \& McNown, 2017; Gunby, Jin, \& Robert Reed, 2017). Therefore, the effect of foreign capital on economic growth is still a subject of debate in the field of empirical research.

There is also a strand of research literature that examines the impacts of official development aid on growth since significant volumes of foreign aid have been channelled to developing nations for more than five decades. Official development aid is one of the major sources of foreign capital flows to developing countries and it is considered as a significant element for less developed countries to fund their developmental programs. Foreign assistance is able to affect economic performance due to some reasons as follows. Firstly, foreign aid can stimulate physical and human capital in developing countries where there is less physical capital and less high-skilled labor. Second, foreign aid can boost productivity through technological transfers as well as promote local business. Third, underdeveloped countries close the saving-investment and technological gaps to achieve economic growth and provide resources such as managerial skills, organizational capacity, and market access (Morrissey, 2001). In empirical studies, foreign assistance and economic growth are still great attention to 
many economists and policymakers due to mixed results. Mallik (2008) examined the effectiveness of foreign aid in economic growth in six very poor African countries by applying Johansen's cointegration test, the results provide that the impact of aid on economic growth was significantly negative. Recently, dynamic time-series evidence for African countries (Juselius, Møller, \& Tarp, 2014) supported that foreign aid is associated with economic growth, particularly from the perspective of positive aggregate developmental role and a similar conclusion from meta-relationship (Mekasha \& Tarp, 2013) also revealed the aid-growth relationship. In addition, Ekanayake and Chatrna (2010) tested the effect of foreign aid in 85 developing countries between Asia, Africa, Latin America and the Caribbean from 1980 to 2007. They concluded that mixed impact of foreign aid on economic growth are found in these countries and the majority of factors lead to the success of aid as economic policies, human capital development.

Our study is also related to foreign direct investment literature, which focuses the examining the effect of FDI on growth. The relationship between FDI flows and economic growth is not a new phenomenon and the existing literature have extensively concerned and debated the relationship. FDI is a significant component of foreign capital inflows that developing countries expect to attract from developed countries. From theories point of view, as one of the main mechanisms to boost productivity, host countries seek FDI with the expectation to benefit from it through knowledge spillover. There are different ways of knowledge spillovers, including technology transfers or bringing the latest processes or managerial skills to the domestic market. Much work has been done to investigate the relationship between FDI and economic growth, however the results have long been a subject of debate because of mixed consensus. Some empirical concluded that FDI is considered as a fundamental engine in the growth of developing countries due to its technology transfer and capital (Anwar \& Sun, 2011; Iamsiraroj, 2016; Keho, 2015; Lean \& Tan, 2011; Sunde, 2017; Tahir, Estrada, \& Afridi, 2019). Alfaro, Chanda, Kalemli-Ozcan, and Sayek (2010) highlighted the important role of the financial market as a mechanism to further enable FDI flows affecting growth. They confirmed that an increase in volumes of FDI flows produces additional gains for financially developed economies. Another strand of the literature is the argument of no positive impact of foreign direct investment on growth (Adams, 2009; Adams \& Opoku, 2015; Akinlo, 2004; Durham, 2004; Gunby et al., 2017; Lean, 2008; Mencinger, 2003; Temiz \& Gökmen, 2014). They explained that the level impact of foreign direct investment on host countries depends on the level of absorptive capacity of its countries, including the level of technological advancement, macroeconomic stability and human capital development.

Recently, many empirical studies have mainly focused on the relationship between foreign debt and economic growth but the impact of external debt accumulation on investment and growth remains questionable for policymakers. It has been witnessed in the last three or four decades that some emerging and developing countries have been using foreign currency loans to promote their economic performance because external debt provides capital inflows to be used for expenditures that can accelerate the pace of economic growth in these countries. On the other hand, the main theories which are the leading explanation for the negative effect between foreign debt and economic growth are called the debt overhang hypothesis of Krugman (1988) and Sachs (1989) then advocated by Cohen (1993). These groups have mainly focused on the negative effect of debt overhang, which is defined as a situation in which the expected returns from any additional investment are low due to the debt service obligations of the debtor countries. The empirical evidence is far from conclusive either supporting or rejecting the external debt-led growth hypothesis. Empirical on both effect sides of external debt are mixed. While there is relatively more evidence in support of the negative effect of the overhang hypothesis between debt and the growth of recipient economies, evidence on positive effects is very limited. The empirical studies on the effect of foreign loans and economic 
growth have found similar findings that foreign loans had negative impact on economic growth (Adams \& Atsu, 2014; Dreher, 2006; Ehigiamusoe \& Lean, 2019; Hameed, Ashraf, \& Chaudhary, 2008). Changyong, Jun, and Chen (2012) claimed that debt would be the most formidable barrier to renewed economic growth when the debt-GDP ratio crosses a certain limit. Afonso and Jalles (2013) reported that higher debt level would higher the expected future tax that adversely affects the growth outcome and employment of the economy owing due to its effect on consumption and investment.

The review of the literature showed that foreign capital inflows with some components bring a significantly positive impact on developing countries. The fact is that there are different kinds of determinants and effects of foreign capital flows on economic growth. Consequently, our paper contributes to the literature by investigating the differential effects of foreign capital flows on economic growth with specific characteristics and the policy environment in Vietnam. The descriptive statistics and data resources are described next.

\section{Data resources and description of variables}

The descriptive statistics and correlation of Vietnam time-series data during the 19892019 period are shown in Table 1 and Table 2 respectively, the former presents the descriptive statistics, and the latter is a correlation analysis of the six variables. GDP is real gross domestic product as a proxy for economic growth measured by the difference of the log of GDP per capita (y) and log of GDP per capita at the initial year ( $\left.\mathrm{y}_{0}\right)$. Foreign capital flows include foreign direct investment (FDI), foreign aid (AID) and external debt (ED), in which variable FDI is foreign direct investment measured by net flows (\% of GDP), AID is foreign aid as a ratio of gross national income GNI, ED is the external debt as a ratio of GNI, GOV is government consumption expenditure as a ratio of GDP, $\mathrm{HC}$ is human capital. All variables are transformed into natural logarithms before analysis. The dataset is mainly collected from the World Development Indicator database of the World Bank except for human capital and GDP which are gathered from Penn World Table version 10.0 developed by Feenstra, Inklaar and Timmer (2015).

Table 1. Descriptive statistics of variables in the period 1989-2019

\begin{tabular}{lcccccc}
\hline & GDP & FDI & AID & ED & GOV & HC \\
\hline Mean & 6.967 & 5.771 & 2.935 & 3.13 & 6.803 & 2.1923 \\
Maximum & 12.907 & 11.939 & 5.941 & 7.909 & 12.339 & 2.87 \\
Minimum & -1.7 & 0.0647 & 0.4437 & 1.466 & 5.465 & 1.696 \\
Std.Dev. & 3.556 & 2.406 & 1.24 & 1.623 & 1.362 & 0.373 \\
Skewness & -0.381 & 0.347 & 0.312 & 1.300 & 2.308 & 0.302 \\
Kurtosis & 3.165 & 3.469 & 3.338 & 4.349 & 9.765 & 1.773 \\
\hline
\end{tabular}

Source: Author's calculations

The results of the correlation matrix reveal that a negative correlation exists between GDP with ED, GOV and HC while a positive correlation between FDI and HC, GDP and FDI. Some studies have concerned the possible existence of high multicollinearity among the explanatory variables that caused estimates to contradict the economic theories (Agung, 2011; Hamsal, 2006). According to Iyoha (2004), the correlation value is more than $0.95 \%$, which makes the multicollinearity among variables. Therefore, there is impossible for multicollinearity among independent variables because all the correlation coefficients are below $0.95 \%$ based on the result reported in Table 2 . 
Table 2. Correlation among variables

\begin{tabular}{lcccccc}
\hline & InGDP & InFDI & InAID & InED & InGOV & InHC \\
\hline $\operatorname{lnFDI}$ & 0.4305 & & & & & \\
$\ln \mathrm{AID}$ & 0.0795 & 0.1956 & & & & \\
$\operatorname{lnED}$ & -0.1271 & -0.4446 & -0.1009 & & & \\
$\operatorname{lnGOV}$ & -0.1515 & 0.1535 & -0.3861 & 0.2628 & & \\
$\operatorname{lnHC}$ & -0.0785 & 0.3662 & -0.4440 & -0.6713 & 0.1602 & \\
\hline
\end{tabular}

Note: $* * *, * *$ and $*$ indicate statistically significant at $1 \%, 5 \%$ and $10 \%$ respectively.

Source: Author's calculations

\section{Econometric methodology}

We employ the autoregressive distributed lag (ARDL) framework by Pesaran and Shin (1995) and Pesaran, Shin, and Smith (2001) to determine the cointegration relationship between foreign capital inflows and economic growth using 1989-2019 time series data of Vietnam. The ARDL bounds test was chosen in this paper because of its advantages in comparison with conventional methodologies, including Engle and Granger (1987) and Johansen (1988). Firstly, the approach is very useful in case of limited sample data (Pesaran et al., 2001). Secondly, the ARDL model has a flexible order of integration without a condition of the same order integration of the variables, which are purely ordered zero $\mathrm{I}(0)$, order one I(1), or a combination of both.

The ARDL model used in this study is specified as follows: $\mathrm{d}\left(\ln G D P_{t}\right)=a_{01}+$

$$
\begin{aligned}
& b_{11} \operatorname{lnGDP}_{t-1}+b_{21} \operatorname{lnFDI}_{t-1}+b_{31} \ln A I D_{t-1}+b_{41} \ln E D_{t-1}+b_{51} \ln G O V_{t-1}+b_{61} \ln H C_{t-1} \\
&+\sum_{i=1}^{q} a_{1 i} d\left(\ln G D P_{t-i}\right)+\sum_{i=1}^{q} a_{2 i} d\left(\ln F D I_{t-i}\right)+\sum_{i=1}^{q} a_{3 i} d\left(\ln A I D_{t-i}\right) \sum_{i=1}^{q} a_{4 i} d\left(\ln E D_{t-i}\right) \\
&+ \sum_{i=1}^{q} a_{5 i} d\left(\ln G O V_{t-i}\right)+\sum_{i=1}^{q} a_{6 i} d\left(\ln H C_{t-i}\right)+\varepsilon_{t}
\end{aligned}
$$

Where $\operatorname{lnGDP}, \operatorname{lnFDI}, \ln \mathrm{AID}, \operatorname{lnED}, \operatorname{lnGOV}, \ln \mathrm{HC}$ are respectively the natural logarithm of GDP per capita, foreign direct investment, foreign aid, external debt, government expenditure and human capital as defined in section $3, \mathrm{~d}$ is the first difference and $\varepsilon_{t}$ are the error terms, $\mathrm{p}$ and $\mathrm{q}$ are the optimal lag length. This study is incorporated two control variables such as human capital and government expenditure. The coefficients such as $b_{1 i}$, $b_{2 i}, b_{3 i}, b_{4 i}, b_{5 i}, b_{6 i}$ are the long-run multipliers while the short-run multipliers are presented in the coefficients of different terms.

To proceed with the ARDL methodology, the first step is to test stationary between the variables by applying unit root tests to confirm the order of integration of the data in this paper. We then test for the order of integration of these series to be certain that there is a long-run relationship between the variables. The presence of the long-run relationship is to proceduce in the bounds test based on a joint $F$ test with the null hypothesis of no cointegration. The value of $\mathrm{F}$ test statistic is compared with the critical values, which are given in two sets; lower bound I(0) and upper bound I(1). The former of lower critical bound value is assumptions of integration of order zero of the ARDL model, the latter bound is based on the assumption of integration of order one of the models. The null hypothesis of no long-run relationship is rejected if the calculated F- statistic is more than the upper bound $\mathrm{I}(1)$, while we fail to reject the $\mathrm{H}_{0}$ when the value of the $\mathrm{F}$ test falls below the lower bound value. Otherwise, the test turns 
out to be inconclusive. Once the long-run relationship is examined, the long-run model is estimated as follows:

$$
\begin{aligned}
\ln G D P_{t}=a_{0}+ & \sum_{i=1}^{p} a_{i 1} \operatorname{lnGDP_{t-i}}+\sum_{i=1}^{q} a_{i 2} \ln F D I_{t-i} \\
& +\sum_{i=1}^{q} a_{i 3} \ln A I D_{t-i} \sum_{i=1}^{q} a_{i 4} \ln E D_{t-i}+\sum_{i=1}^{q} a_{i 5} \ln G O V_{t-i}+\sum_{i=1}^{q} a_{i 6} \ln H C_{t-i}+\varepsilon_{1 t}
\end{aligned}
$$

Using the ordinary least square (OLS) method, the first equation is to estimate that the lags orders of ARDL model are selected by either the lowest Akaike Information Criterion (AIC) or Schwarz bayesian Criterion (SBC). The maximum of two Lag lengths for annual data is recommended by Pesaran et al. (2001), hence, the lag length is chosen with the lowest AIC. The short-run and long-run Granger causality among the variables are specified with the presence of the error correction model ECM.

$$
\begin{gathered}
\mathrm{d}\left(\ln G D P_{t}\right)=a_{02}+\sum_{i=1}^{p} a_{1} d\left(\operatorname{lnGDP_{t-i})}+\sum_{i=1}^{q} a_{2} d\left(\ln F D I_{t-i}\right)+\sum_{i=1}^{q} a_{3} d\left(\ln A I D_{t-i}\right)\right. \\
+\sum_{i=1}^{q} a_{4} d\left(\ln E D_{t-i}\right)+\sum_{i=1}^{q} a_{5} d\left(\ln G O V_{t-i}\right)+\sum_{i=1}^{q} a_{6} d\left(\ln H C_{t-i}\right)+\alpha E C T_{t-1}+\varepsilon_{2 t}
\end{gathered}
$$

Where $\alpha$ is the coefficient of the error correction term (ECT) and it represents the convergence speed of the model into the equilibrium. The sign of the error correction term will be negative and statistically significant to be certain of convergence to the long-run equilibrium. Ramsey RESET test is also applied to assess parameters stability in this study.

\section{Empirical results}

\subsection{Unit roots tests}

To determine the level of integration of the model variables, the unit root test is

\begin{tabular}{|c|c|c|c|c|c|c|}
\hline \multirow[b]{2}{*}{ Variables } & \multicolumn{3}{|c|}{ Augmented Dickey-Fuller (ADF) } & \multicolumn{3}{|c|}{ Phillips-Person (PP) } \\
\hline & Level & $\begin{array}{c}\text { First } \\
\text { difference }\end{array}$ & Remark & Level & $\begin{array}{c}\text { First } \\
\text { difference }\end{array}$ & Remark \\
\hline $\operatorname{lnGDP}$ & $-5.351 * * *$ & - & $\mathrm{I}(0)$ & $-5.919 * * *$ & & $\mathrm{I}(0)$ \\
\hline $\operatorname{lnFDI}$ & -2.217 & $-4.106^{* * *}$ & $\mathrm{I}(1)$ & -2.125 & $-14.113 * * *$ & $\mathrm{I}(1)$ \\
\hline $\ln \mathrm{AID}$ & -0.082 & $-3.405^{* *}$ & $\mathrm{I}(1)$ & -2.255 & $-10.396^{* * *}$ & $\mathrm{I}(1)$ \\
\hline $\operatorname{lnED}$ & -1.466 & $-2.783^{*}$ & $\mathrm{I}(1)$ & -0.77 & $-5.166 * * *$ & $\mathrm{I}(1)$ \\
\hline $\operatorname{lnGOV}$ & $-4.383^{* * *}$ & - & $\mathrm{I}(0)$ & $-4.49 * * *$ & & $\mathrm{I}(0)$ \\
\hline $\ln \mathrm{HC}$ & $-4.416^{* * *}$ & - & $\mathrm{I}(0)$ & $-5.734 * * *$ & & $\mathrm{I}(0)$ \\
\hline
\end{tabular}
conducted by using both Augmented Dickey-Fuller (ADF) and Phillips-Perron (PP) unit root tests.

Table 3. Unit root tests results

Note: $(* * *),(* *)$, and $(*)$ denotes $1 \%, 5 \%$ and $10 \%$ levels of statistical significance.

Source: Author's calculations

Table 3 indicates that GDP, government expenditure GOV and human capital HC variables are integrated at order zero $\mathrm{I}(0)$ at $1 \%$ significant level by both ADF and PP tests 
while foreign direct investment FDI, foreign aid AID and external debt ED variables are integrated at order one I(1) at $1 \%$ level of significance. With the confirmation of a mixture of I(0) and I(1) variables, ARDL cointegration methodology is an appropriate methodology to examine a long-run relationship between the variables in this study.

\subsection{ARDL bounds tests for cointegration}

To empirically analyze the existence of a long-run relationship and short-run dynamic interaction among the variables in this study, the autoregressive distributed lag (ARDL) cointegration method is applied, which was developed by Pesaran and Shin (1995) and Pesaran et al. (2001). One of the two main advantages of this methods comparison with other conventional integration methods is that all variables under study in ARDL model need not to be of the same order of integration. All variables are able to integrate order one or order zero. The second advantage is that ARDL technique is also helpful for both estimations of short-run and long-run models without biased estimates.

Table 4: Cointegration test results

\begin{tabular}{|c|c|c|c|}
\hline $\begin{array}{c}\text { Dependent } \\
\text { variables }\end{array}$ & Functions & F-statistic & Decision \\
\hline $\operatorname{lnGDP}$ & $\begin{array}{c}\ln G D P=f(\operatorname{lnFDI}, \ln \mathrm{AID}, \ln \mathrm{\operatorname {ln }}, \ln \mathrm{GOV}, \\
\ln \mathrm{HC})\end{array}$ & $6.597 * * *$ & Cointegration \\
\hline $\operatorname{lnFDI}$ & $\begin{array}{c}\operatorname{lnFDI}=\mathrm{f}(\ln \mathrm{GDP}, \ln \mathrm{AID}, \ln \mathrm{\operatorname {ln }}, \ln \mathrm{GOV}, \\
\ln \mathrm{HC})\end{array}$ & $39.242 * * *$ & Cointegration \\
\hline $\ln A I D$ & $\begin{array}{c}\ln A I D=f(\ln G D P, \ln F D I, \ln E D, \ln G O V, \\
\ln H C)\end{array}$ & $4.797 * * *$ & Cointegration \\
\hline $\operatorname{lnED}$ & $\begin{array}{c}\ln E D=f(\ln G D P, \ln F D I, \ln A I D, \ln G O V, \\
\ln H C)\end{array}$ & 2.859 & No cointegration \\
\hline
\end{tabular}

Critical values

\begin{tabular}{ccc}
\hline Significant level & $\begin{array}{c}\text { Lower bounds } \\
\mathbf{I}(\mathbf{0})\end{array}$ & $\begin{array}{c}\text { Upper bounds I(1) } \\
1 \%\end{array}$ \\
$5 \%$ & 3.41 & 3.68 \\
$10 \%$ & 2.62 & 3.35
\end{tabular}

Note: $(* * *),(* *)$, and $(*)$ denote $1 \%, 5 \%$ and $10 \%$ levels of statistical significance, respectively, the null hypothesis of no evidence of cointegration. The optimal lag is determined by AIC. Lower and upper-bounds critical values are obtained from Pesaran et al. (2001).

Source: Author's calculations

In this study, our ARDL model is chosen based on the Akaike Information Criteria (AIC) for lag selection criteria. The results of ARDL- bounds test with estimated F statistics 
values is presented in Table 4. The bounds test results reveal that there is the existence of a cointegration relationship between economic growth and the regressors in all the models except the external debt variable when this variable is the dependent variable as in equation ( 1 ). The results in Table 4 reveal that the F-statistics value exceeds the upper critical bounds value at $1 \%$ level of significance. That means the existence of cointegration among the variables. However, the external debt variable (ED) is used as the dependent variable, the null hypothesis of no cointegration is not rejected because the calculated $\mathrm{F}$ statistics is less than the lower critical value at the $5 \%$ level.

\subsection{Granger short-run and long-run causality tests}

The results of the long-run model are shown in Table 5. The estimated coefficients of the long-run relationship are significant for foreign direct investment FDI, foreign aid AID and human capital but not significant for external debt ED and government consumption expenditure GOV. Foreign direct investment has a significant positive impact on economic growth at the 5\% level. The long-run results indicate that a $1 \%$ increase in foreign direct investment is associated with a $1.26 \%$ increase in growth. The foreign aid variable has a negative sign and is significant at the 5\% level. This is quite surprising but is consistent with Ehigiamusoe and Lean (2019), Adams and Atsu (2014) and Kodama (2012) that these studies showed negative effect of aid flows occuring in many developing nations because foreign aid is wasted. Baafi Antwi (2010) reported that flows of international aid become additional capital to domestic resources, which speed the growth process of the economy. However, the author noted the poor performance of foreign aid in the long run because donor conditionality has some effects on loan efficient allocation and thus leads to poor impact of aid on growth. While the insignificant impact of external debt on economic growth found in this study is consistent with most previous studies.

Table 5. Estimated Long Run Coeffecents using the ARDL Approach- ARDL $(1,1,1,0,0,1)$ based on AIC

\begin{tabular}{cccc}
\hline Variable & Coefficient & t-Statistic & Probability \\
\hline $\ln F D I$ & $1.26^{* *}$ & 2.17 & 0.043 \\
$\ln \mathrm{AID}$ & $0.89^{* *}$ & -2.11 & 0.048 \\
$\operatorname{lnED}$ & 0.488 & 1.18 & 0.250 \\
$\operatorname{lnGOV}$ & -1.045 & -0.71 & 0.485 \\
$\ln H C$ & $3.38^{* *}$ & 2.27 & 0.035 \\
$\mathrm{C}$ & 0.163 & 0.11 & 0.917 \\
R-squared & 0.48 & - & - \\
F-statistic & $2.02^{* *}$ & - & 0.0421
\end{tabular}

Note: $(* * *),(* *)$, and $(*)$ denotes $1 \%, 5 \%$ and $10 \%$ levels of statistical significance.

Source: Author's calculations

Regarding the control variables included in the model, the results indicate that human capital has a significant impact on economic growth at 5\% level of significance and this is consistent with the economic theory about the relationship between human capital and economic growth (Barro, 1991; Mankiw et al., 1992) and empirical studies (Aghion, Bacchetta, Ranciere, \& Rogoff, 2009; Dinh Su \& Phuc Nguyen, 2020; Ehigiamusoe \& Lean, 2019). 
However, government consumption expenditure is not significant and has a negative impact on economic growth in Vietnam, which is consistent with some empirical studies (Lean \& Tan, 2011; Rousseau \& Yilmazkuday, 2009; Samargandi, Fidrmuc, \& Ghosh, 2015). There are comment consequences in most developing countries with inefficient and unproductive government expenditure (Rousseau \& Yilmazkuday, 2009). According to Samargandi et al. (2015), an increase in government expenditure could distort some effects such as an increase in the burden on citizens in the future that leads to decreasing private spending and investment, therefore government expenditure could negatively impact economic growth.

Table 6. Short Run Results

\begin{tabular}{cccc}
\hline Variable & Coefficient & t-Statistic & Probability \\
\hline $\mathrm{d}(\ln F D I)$ & $0.731^{* *}$ & 2.24 & 0.037 \\
$\mathrm{~d}(\ln \mathrm{nID})$ & -0.88 & -1.64 & 0.117 \\
$\mathrm{~d}(\ln \mathrm{N})$ & 0.4189 & 1.16 & 0.258 \\
$\mathrm{~d}(\operatorname{lnGOV})$ & -0.901 & -0.72 & 0.482 \\
$\mathrm{~d}(\ln H C)$ & $3.481^{* *}$ & 2.29 & 0.033 \\
$\mathrm{C}$ & 0.1627 & 0.11 & 0.917 \\
ECT(-1) & $-1.16^{* * *}$ & -6.89 & 0.000 \\
R-squared & 0.77 & - & - \\
F-statistic & $7.07 * * *$ & - & 0.000 \\
\hline
\end{tabular}

Note: $(* * *),(* *)$, and $(*)$ denotes $1 \%, 5 \%$ and $10 \%$ levels of statistical significance.

Source: Author's calculations

The estimated short-run coefficients are reported in Table 6 . The error correction factor measures the speed of adjustment back to the long-run equilibrium. The coefficient of the lagged error correction term is significant at $1 \%$ level with the expected sign. When the value of the error correction term is between -2 and -1 then the lagged error correction term will be in a damping manner about the equilibrium path. Its value is estimated at 1.15 , which implies that instead of monotonically converging back to the equilibrium path directly, the error correction process fluctuates around the long-run value in a damening manner before convergence to the equilibrium path.

To employ the stability of the long-run coefficient in ARDL modelling, the short-run relationship is examined by testing residuals. Once the ECM model has been conducted, the squared cumulative sum of recursive residuals (CUSUM) test is examing to assess the stability of long-run parameters (Pesaran \& Pesaran, 1997). The CUSUM test result has been examined and the graph is plotted as given in Figure 3. The graph showed that the estimated line is lying inside the critical bands of the $5 \%$ confidence interval of parameter stability. Therefore, the results reported earlier are reliable and stable. 
Figure 3. Stability tests result

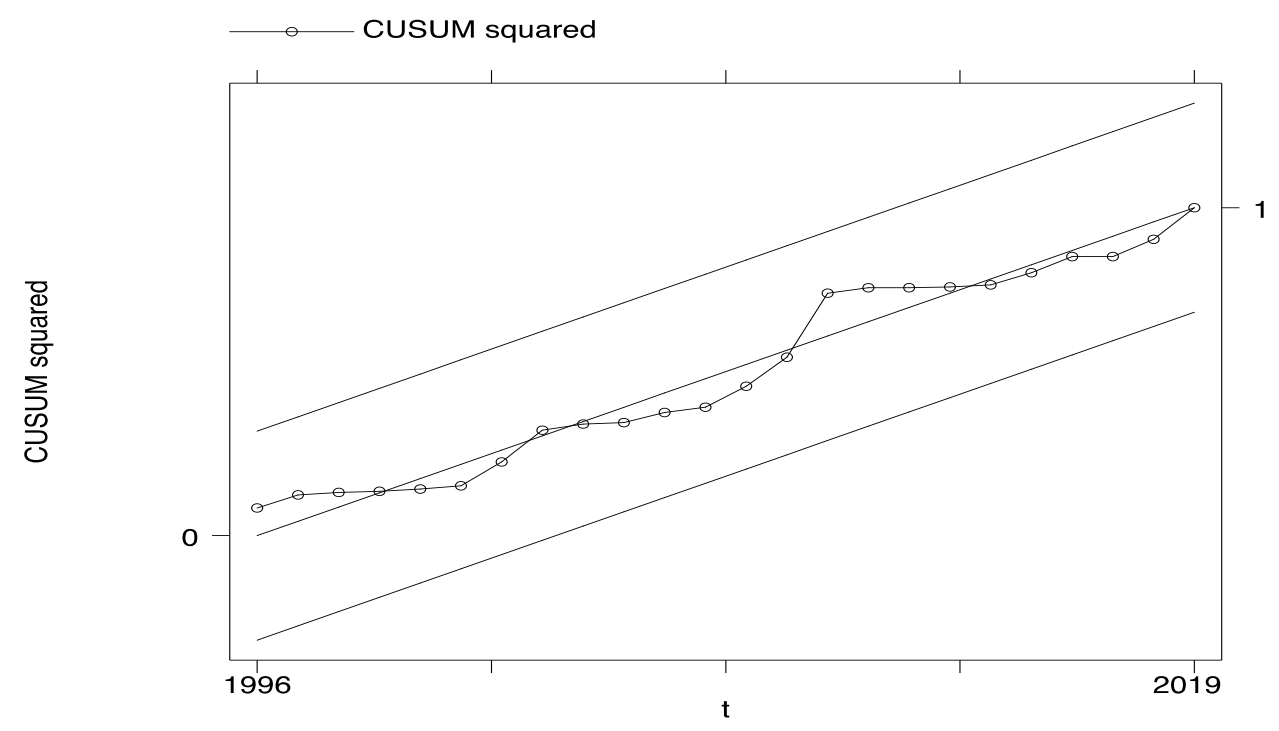

Source: Author's calculations

The results of the short-run Granger causality tests are shown in Table 7. Granger causality is only investigated in the models having cointegration relationship, therefore causality is not examined in the equation with external debt as the dependent variable. In the short run, the value of F-statistics on the independent variables suggests that at the $10 \%$ level or better there is bi-directional Granger causality between foreign direct investment and government, between human capital and foreign direct investment and between external debt and foreign direct investment. It is interesting that the existence of bi-directional causality between foreign direct investment and human capital confirm the widespread belief that FDI can generate positive productivity externalities for a host country and generate positive spillovers in case of the mobility of well-trained labour channel. The finding means that foreign direct investment and human capital are complementary in producing productivity growth in Vietnam. Human capital, therefore becomes productive in absorbing FDI inflows. The finding is in line with the study of $\mathrm{Vu}$ (2008), which found evidence of the significant effect of FDI on human capital in Vietnam. As such, it is necessary to boost human capital since skilled workers have been sufficient to attract foreign direct investment. Besides, the unidirectional Granger causality running from foreign direct investment to economic growth is interesting and indicate that FDI promotes growth in the short run and is one of the main drivers of economic growth in Vietnam.

Table 7. Granger Causality test results

\begin{tabular}{|c|c|c|c|c|c|c|c|}
\hline \multirow{2}{*}{$\begin{array}{c}\text { Dependent } \\
\text { variable }\end{array}$} & \multicolumn{6}{|c|}{ F statistics } & \multirow{2}{*}{$\begin{array}{c}\text { Direction of } \\
\text { causality }\end{array}$} \\
\hline & d(InGDP) & d(InFDI) & d(lnAID) & $\mathbf{d}(\operatorname{lnED})$ & d(InGOV) & $\mathbf{d}(\mathbf{H C})$ & \\
\hline $\mathrm{d}(\operatorname{lnGDP})$ & --- & $4.441 * *$ & 0.2557 & 0.085 & $2.887 *$ & 0.339 & $\begin{array}{l}\mathrm{FDI} \rightarrow \mathrm{GDP} ; \\
\mathrm{GOV} \rightarrow \mathrm{GDP}\end{array}$ \\
\hline
\end{tabular}




\begin{tabular}{|c|c|c|c|c|c|c|c|}
\hline $\mathrm{d}(\operatorname{lnFDI})$ & 1.266 & ---- & 0.1761 & $2.888^{*}$ & $4.942 * *$ & $5.744^{* *}$ & $\begin{array}{c}\mathrm{ED} \rightarrow \mathrm{FDI} ; \\
\mathrm{GOV} \rightarrow \mathrm{FDI} ; \\
\mathrm{HC} \rightarrow \mathrm{FDI}\end{array}$ \\
\hline $\mathrm{d}(\ln \mathrm{AID})$ & 0.3012 & 1.113 & ----- & 0.292 & 1.074 & $6.729 * * *$ & $\mathrm{HC} \rightarrow \mathrm{AID}$ \\
\hline $\mathrm{d}(\ln \mathrm{GOV})$ & 0.196 & $5.645^{* *}$ & 0.271 & $23.456 * * *$ & ----- & $21.791 * * *$ & $\begin{array}{l}\mathrm{FDI} \rightarrow \mathrm{GOV} ; \\
\mathrm{ED} \rightarrow \mathrm{GOV} ; \\
\mathrm{HC} \rightarrow \mathrm{GOV}\end{array}$ \\
\hline $\mathrm{d}(\operatorname{lnHC})$ & $6.4578 * *$ & $5.683^{* *}$ & 1.915 & $16.148 * * *$ & 2.398 & ------ & $\begin{array}{c}\mathrm{GDP} \rightarrow \mathrm{HC} \\
\mathrm{FDI} \rightarrow \mathrm{HC} \\
\mathrm{ED} \rightarrow \mathrm{HC}\end{array}$ \\
\hline
\end{tabular}

Note: $(* * *),(* *)$, and $(*)$ denotes $1 \%, 5 \%$ and $10 \%$ levels of statistical significance.

Source: Author's calculations

Table 8. Results of diagnostic tests

\begin{tabular}{lccc}
\hline \multicolumn{1}{c}{ Diagnostics } & Null hypothesis & $\chi^{2}$ statistic & Conclusion \\
\hline $\begin{array}{c}\text { Breusch-Godfrey serial } \\
\text { correlation test }\end{array}$ & $\mathrm{H}_{0}$ : no serial correlation & $0.622(0.4305)$ & Don't reject $\mathrm{H}_{0}$ \\
& & & \\
White Heteroskedsticity test & $\mathrm{H}_{0}$ : no heteroskedasticity & $(0.414)$ & Don't reject $\mathrm{H}_{0}$ \\
& & & Don't reject $\mathrm{H}_{0}$
\end{tabular}

Note: P-values are in parenthesis.

Source: Author's calculations.

Some diagnostic tests have been conducted in this study to check the validity of the estimated ARDL model based on some tests, namely, serial correlations (Breusch-Godfrey test), normality of errors (Jarque-Bera test) and heteroscedasticity test. Results of the diagnostic tests presented in Table 8 suggest that there is no evidence of autocorrelation in ARDL model. The model also all passes the normality test and normality of errors.

\section{Conclusions and recommendations}

This research investigates the impact of international capital flows on economic growth in Vietnam among the series of economic growth, foreign direct investment, foreign aid, external debt, government consumption expenditure and human capital for the period 19892019. We employ ARDL bounds testing framework to investigate the existence of a long-run relationship among the above noted series, and Granger causality to test the direction of causality between the variables. The results show that the components of foreign capital flows in Vietnam have different effects on outcomes. Foreign direct investment emerged as the most significant contributor to economic growth, while foreign aid has a negative effect on economic 
growth. The current trends in international capital flows and their challenging prospects could raise major issues for Vietnam that must continue to depend on substantial external financing to achieve economic growth and social objectives. Together with improvement of aid implementation and absorption, Vietnam must deal with a majority of problems to create conducive environment to attract stable international capital flows.

First, the findings of this study on the relationship between foreign aid and economic growth in Vietnam shows that the foreign aid received by Vietnam over the years has detrimental effects on the growth in the long run, which is consistent with the results of Fasanya and Onakoya (2012), Adams and Atsu (2014), Klobodu and Adams (2016) and Ehigiamusoe and Lean (2019) who demonstrated that the effectiveness of aid should promote in a host country. As a developing country, Vietnam is facing a shortage of capital, therefore, foreign capital are important determinants that drive economic growth. Foreign aid, however, is necessary but not a sufficient condition for growth as the study's finding, therefore, Vietnam should reform to achieve the effectiveness of aid because aid effectiveness depends on the policy space. Policymakers should improve to deepen financial openness to enhance the effectiveness of aid because deepening financial absorptive capacity allow monetary management to mitigate the negative incentive effects of aid flows. Ang (2010) and Nkusu and Sayek (2004) found that financial openness can play a facilitative role in enhancing economic growth because the interaction variable between aid and financial liberalization is significant and positively correlated with economic growth. Vietnam needs to rely on international flows such as foreign aid to meet the external financing requirement for the by itself is not enough to promote growth but rather the policy and macroeconomic environment for growth.

Second, aside from attracting international capital flows, Vietnam should place on the labor-intensive export-oriented project as the priority in project licensing to gain productivity and lead to sustained growth based on the development of human capital, away from investment in capital-intensive import-substitution and domestic consumption industries. The paper's findings show that human capital has a positively significant impact on economic growth in the long run and there is existence in the bi-directional Granger causality between human capital and foreign direct investment. Therefore, rather then make some mistake of locking into inefficient capital stock which has led to economic decline as in some African countries, policymakers should provide vocational training to increase high skilled workers. Besides, the strong foundation for human resources with the educated program is an advantage for Vietnam in case of attracting international capital flows especially foreign direct investment because high skilled resources tend to absorb technology transfer, management skills and gain productivity. With industrious labour, Vietnam should enhance the development impact of international capital flows, especially the beneficial effect of FDI associated with the efficiency of resources can be raised. Vietnam should diversify international investment having linages with many sectors of the economy in order to favour synergies that gain productivity through spillover effects.

Finally, on the question of how to enhance the development effects and effectiveness of international flows such as foreign direct investment and foreign aid on Vietnamese economy, macroeconomic environment is an essential and key requirement to fulfil the qualify for the effectiveness of international capital flows on economic growth. Institutional infrastructure and government effectiveness are major determinants of the policy environment to reduce corruption and promote economic stability to gain sustained growth. In addition, it is worth mentioning that the insight finding of the study is the bi-directional Granger cause between foreign direct investment and human capital, therefore, policymakers should focus on seeking assistance for productive investment from foreign direct investment flows in sectors of the economy that would gain productivity, revenue and promote growth. 


\section{References}

Adams, S. (2009). Foreign direct investment, domestic investment, and economic growth in Sub-Saharan Africa. Journal of policy modeling, 31(6), 939-949. https://doi.org/10.1016/j.jpolmod.2009.03.003.

Adams, S., \& Atsu, F. (2014). Aid dependence and economic growth in Ghana. Economic Analysis and Policy, 44(2), 233-242. https://doi.org/10.1016/j.eap.2014.05.001.

Adams, S., \& Opoku, E. E. O. (2015). Foreign direct investment, regulations and growth in sub-Saharan Africa. Economic Analysis and Policy, 47, 48-56. https://doi.org/10.1016/j.eap.2015.07.001.

Afonso, A., \& Jalles, J. T. (2013). Growth and productivity: The role of government debt. International Review of Economics \& Finance, 25, 384-407. https://doi.org/10.1016/j.iref.2012.07.004.

Aghion, P., Bacchetta, P., Ranciere, R., \& Rogoff, K. (2009). Exchange rate volatility and productivity growth: The role of financial development. Journal of monetary economics, 56(4), 494-513. https://doi.org/10.1016/j.jmoneco.2009.03.015.

Agung, I. G. N. (2011). Time series data analysis using EViews: John Wiley \& Sons.

Akinlo, A. E. (2004). Foreign direct investment and growth in Nigeria: An empirical investigation. Journal of policy modeling, 26(5), 627-639. https://doi.org/10.1016/j.jpolmod.2004.04.011.

Alfaro, L., Chanda, A., Kalemli-Ozcan, S., \& Sayek, S. (2010). Does foreign direct investment promote growth? Exploring the role of financial markets on linkages. Journal of development Economics, 91(2), 242-256. https://doi.org/10.1016/j.jdeveco.2009.09.004.

Ang, J. B. (2010). Does foreign aid promote growth? Exploring the role of financial liberalization. Review of Development Economics, 14(2), 197-212. https://doi.org/10.1111/j.1467-9361.2010.00547.x.

Anwar, S., \& Sun, S. (2011). Financial development, foreign investment and economic growth in Malaysia. Journal of Asian economics, 22(4), 335-342. https://doi.org/10.1016/j.asieco.2011.04.001.

Baafi Antwi, J. (2010). Ghana's Economic Growth in perspective: A time series approach to Convergence and Growth Determinants. Retrieved from https://mpra.ub.unimuenchen.de/23455/.

Barro, R. J. (1991). Economic Growth in a Cross Section of Countries. The Quarterly Journal of Economics, 106(2), 407-443. https://doi.org/10.2307/2937943.

Changyong, X., Jun, S., \& Chen, Y. (2012). Foreign debt, economic growth and economic crisis. Journal of Chinese Economic and Foreign Trade Studies. https://doi.org/10.1108/17544401211233534. 
Cohen, D. (1993). Low Investment and Large LDC Debt in the 1980's. The American Economic Review, 437-449. Retrieved from https://www.jstor.org/stable/2117527.

Dinh Su, T., \& Phuc Nguyen, C. (2020). Foreign financial flows, human capital and economic growth in African developing countries. International Journal of Finance \& Economics. https://doi.org/10.1002/ijfe.2310.

Dreher, A. (2006). IMF and economic growth: The effects of programs, loans, and compliance with conditionality. World Development, 34(5), 769-788. https://doi.org/10.1016/j.worlddev.2005.11.002.

Durham, J. B. (2004). Absorptive capacity and the effects of foreign direct investment and equity foreign portfolio investment on economic growth. European economic review, 48(2), 285-306. https://doi.org/10.1016/S0014-2921(02)00264-7.

Ehigiamusoe, K. U., \& Lean, H. H. (2019). Foreign capital inflows and economic growth in Nigeria: any nexus? Journal of African Business, 20(4), 455-471. https://doi.org/10.1080/15228916.2019.1581010.

Ekanayake, E., \& Chatrna, D. (2010). The effect of foreign aid on economic growth in developing countries. Journal of International Business and cultural studies, 3, 1.

Engle, R. F., \& Granger, C. W. J. (1987). Co-Integration and Error Correction: Representation, Estimation, and Testing. Econometrica, 55(2), 251-276. doi: $10.2307 / 1913236$.

Fasanya, I. O., \& Onakoya, A. B. (2012). Does foreign aid accelerate economic growth? An empirical analysis for Nigeria. International journal of economics and financial issues, 2(4), 423-431.

Feenstra, R.C., Inklaar, R., \& Timmer, M.P. (2015). The Next Generation of the Penn World Table. American Economic Review, 105, 3150-3182. Retrieved from http://www.ggdc.net/pwt/

Fischer, S. (1997). Capital Account Liberalization and the Role of the IMF: International Monetary Fund.

General Statistics Office. (2019). Socio-Economic situation in the fourth quarter and the whole year 2019. Retrieved from https://www.gso.gov.vn/en/data-andstatistics/2020/01/socio-economic-situation-in-the-fourth-quarter-and-the-whole-year$\underline{2019 /}$.

Goh, S. K., Sam, C. Y., \& McNown, R. (2017). Re-examining foreign direct investment, exports, and economic growth in asian economies using a bootstrap ARDL test for cointegration. Journal of Asian economics, 51, 12-22. https://doi.org/10.1016/j.asieco.2017.06.001.

Grossman, G. M., \& Helpman, E. (1991). Innovation and growth in the global economy. Cambridge, Mass.: MIT Press. 
Gunby, P., Jin, Y., \& Robert Reed, W. (2017). Did FDI Really Cause Chinese Economic Growth? A Meta-Analysis. World Development, 90, 242-255. https://doi.org/10.1016/j.worlddev.2016.10.001.

Hameed, A., Ashraf, H., \& Chaudhary, M. A. (2008). External debt and its impact on economic and business growth in Pakistan. International research journal of finance and economics, 20(1), 132-140.

Hamsal, M. (2006). The effect of paradoxical strategies on firm performance: an empirical study of Indonesian banking industry. Disertation, Graduate School of Management, Faculty of Economics, Universitas Indonesia.

Iamsiraroj, S. (2016). The foreign direct investment-economic growth nexus. International Review of Economics \& Finance, 42, 116-133. https://doi.org/10.1016/j.iref.2015.10.044.

Iyoha, M. (2004). Applied econometrics. Benin City. Mindex Publishing.

Jhingan, M. (2010). Macroeconomic Theory 12th Edition Vrinda Publishing (p) Ltd. In: Delhi.

Johansen, S. (1988). Statistical analysis of cointegration vectors. Journal of Economic Dynamics and Control, 12(2), 231-254. https://doi.org/10.1016/0165-1889(88)90041$\underline{3}$.

Juselius, K., Møller, N. F., \& Tarp, F. (2014). The long-run impact of foreign aid in 36 African countries: Insights from multivariate time series analysis. Oxford Bulletin of Economics and statistics, 76(2), 153-184. https://doi.org/10.1111/obes.12012.

Keho, Y. (2015). Foreign Direct Investment, Exports and Economic Growth: Some African Evidence. Journal of Applied Economics \& Business Research, 5(4), 209-219.

Klobodu, E. K. M., \& Adams, S. (2016). Capital flows and economic growth in Ghana. Journal of African Business, 17(3), 291-307. https://doi.org/10.1080/15228916.2016.1169784.

Kodama, M. (2012). Aid unpredictability and economic growth. World Development, 40(2), 266-272. https://doi.org/10.1016/j.worlddev.2011.07.015.

Krugman, P. (1988). Financing vs. forgiving a debt overhang. Journal of development Economics, 29(3), 253-268. https://doi.org/10.1016/0304-3878(88)90044-2.

Lean, H. H. (2008). The impact of foreign direct investment on the growth of the manufacturing sector in Malaysia. International Applied Economics and Management Letters, 1(1), 41-45.

Lean, H. H., \& Tan, B. W. (2011). Linkages between Foreign Direct Investment, Domestic Investment and Economic Growth in Malaysia. Journal of Economic Cooperation \& Development, 32(4), 75-96. 
Mallik, G. (2008). Foreign Aid and Economic Growth: A Cointegration Analysis of the Six Poorest African Countries. Economic Analysis \& Policy, 38(2).

Mankiw, N. G., Romer, D., \& Weil, D. N. (1992). A Contribution to the Empirics of Economic Growth. The Quarterly Journal of Economics, 107(2), 407-437.

Mekasha, T. J., \& Tarp, F. (2013). Aid and growth: What meta-analysis reveals. The journal of development studies, 49(4), 564-583. https://doi.org/10.1080/00220388.2012.709621.

Mencinger, J. (2003). Does foreign direct investment always enhance economic growth? Kyklos, 56(4), 491-508. https://doi.org/10.1046/j.0023-5962.2003.00235.x.

Morrissey, O. (2001). Does aid increase growth? Progress in development studies, 1(1), 3750. https://doi.org/10.1177/146499340100100104.

Morrissey, O. (2012). FDI in Sub-Saharan Africa: Few linkages, fewer spillovers. The European Journal of Development Research, 24(1), 26-31. https://doi.org/10.1057/ejdr.2011.49.

Ndikumana, L., \& Sarr, M. (2019). Capital flight, foreign direct investment and natural resources in Africa. Resources Policy, 63, 101427. https://doi.org/10.1016/j.resourpol.2019.101427

Nguyen, P. C., \& Pham, G. Q. (2016). Impact of foreign capital flows and trade openness on economic growth. Banking Review, 6.

Nguyen, T. H. T. B. (2016). The impact of international capital flows on economic growth: the case of Vietnam. International Review of Business Research Papers, 12(1), 159170.

Nkusu, M., \& Sayek, S. (2004). Local financial development and the aid-growth relationship. SSRN. http://dx.doi.org/10.2139/ssrn.879063.

Pesaran, M. H., \& Pesaran, B. (1997). Working with microfit 4.0. Camfit Data Ltd, Cambridge. Retrieved from https://proformas.ljmu.ac.uk/7515AE.pdf.

Pesaran, M. H., \& Shin, Y. (1995). An autoregressive distributed lag modelling approach to cointegration analysis.

Pesaran, M. H., Shin, Y., \& Smith, R. J. (2001). Bounds testing approaches to the analysis of level relationships. J. Appl. Econ, 16(3), 289-326. https://doi.org/10.1002/jae.616.

Rousseau, P. L., \& Yilmazkuday, H. (2009). Inflation, financial development, and growth: A trilateral analysis. Economic Systems, 33(4), 310-324. https://doi.org/10.1016/j.ecosys.2009.06.002.

Sachs, J. D. (1989). Introduction to "Developing Country Debt and Economic Performance, Volume 1: The International Financial System". In Developing Country Debt and 
Economic Performance, Volume 1: The International Financial System (pp. 1-36): National Bureau of Economic Research, Inc.

Samargandi, N., Fidrmuc, J., \& Ghosh, S. (2015). Is the relationship between financial development and economic growth monotonic? Evidence from a sample of middleincome countries. World Development, 68, 66-81. https://doi.org/10.1016/j.worlddev.2014.11.010.

Sunde, T. (2017). Foreign direct investment, exports and economic growth: ADRL and causality analysis for South Africa. Research in International Business and Finance, 41, 434-444. https://doi.org/10.1016/j.ribaf.2017.04.035.

Tahir, M., Estrada, M. A. R., \& Afridi, M. A. (2019). Foreign inflows and economic growth: An emiprical study of the SAARC region. Economic Systems, 43(3-4), 100702. https://doi.org/10.1016/j.ecosys.2019.100702.

Tang, S., Selvanathan, E. A., \& Selvanathan, S. (2008). Foreign direct investment, domestic investment and economic growth in China: A time series analysis. World Economy, 31(10), 1292-1309. https://doi.org/10.1111/j.1467-9701.2008.01129.x.

Temiz, D., \& Gökmen, A. (2014). FDI inflow as an international business operation by MNCs and economic growth: An empirical study on Turkey. International Business Review, 23(1), 145-154. https://doi.org/10.1016/j.ibusrev.2013.03.003.

Todaro, M. P., \& Smith, S. C. (2011). Economic development (11th ed. ed.). Boston, Mass.: Addison-Wesley.

$\mathrm{Vu}, \mathrm{T}$. B. (2008). Foreign direct investment and endogenous growth in Vietnam. Applied economics, 40(9), 1165-1173. https://doi.org/10.1080/00036840600749433.

World Bank. (2021). World Development Indicators. Washington, DC: World Bank. Retrieved from https://databank.worldbank.org/source/world-developmentindicators/preview/ddperror.aspx\#. 


\title{
LEGAL PROTECTION FOR DEATH PENALTY CONVICTS WHO ARE NOT EXECUTED IMMEDIATELY AFTER THE PERMANENT LEGAL FORCE
}

\author{
ABDUL AZIS MUHAMMAD ${ }^{1}$ \\ PRIJA DJATMIKA ${ }^{2}$ \\ DHIANA PUSPITAWATI ${ }^{3}$ \\ NURINI APRILIANDA ${ }^{4}$
}

\begin{abstract}
The purpose of this research is to determine the concept of legal protection for death penalty convicts who are not executed immediately after permanent legal force in the future. This research is a normative legal research with the approach of Law, History, Comparison, Philosophy and Cases. The legal materials used are primary, secondary and tertiary with analytical techniques using perspective analysis. The results of this research indicate that at the Judicial Review stage, the Criminal Code Procedure must set a time limit for submitting a judicial review application since the decision has permanent legal force (inkracht van gewijsde). The execution of the judge's decision that imposes the death penalty on the convict who submits the application for judicial review and clemency must be strictly regulated.
\end{abstract}

Keywords: Human Right, Legal Protection, death penalty convict, legal force

JEL Codes: K15, K23, K38, K42

\section{Introduction}

Basically all forms of conviction are seizure for people's rights. Dead criminal is the heaviest criminal in Indonesia's positive law (Sapardjaja, 2007). Therefore, in the application of die criminal providing facilities in the form of legal efforts in the judicial process that must be passed, such as appeal, cassation, review and clemency. The right to life is not a rule without limitation (absolute). Dead criminal is still necessary if the actions of criminals are very cruel and do not take into account the aspects of humane and equitable life.

According to the International Convention on Civil and Political Rights (International Covenant on Civil and Political Rights/ICCPR), the right to life is a right that cannot be reduced (non derogable rights). Similarly, the United Nations Human Rights Commission always issued a resolution calling for countries that have not eliminated the dead criminal commitorium of execution. Indeed, the International Covenant on Civil and Political Rights (ICCPR) does not forbid about the possibility of the implementation of the criminal dead. Some countries that are still applying die criminal in its positive law include Indonesia, China, Iran, Iraq, Pakistan, Sudan and even the United States who are trusted as supporters of human rights and democracy still retain punishments in 38 of the 50 states in the United States.

\footnotetext{
${ }^{1}$ Student at Faculty of Law, Brawijaya University, Malang City, Indonesia, e-mail: abdulazis.fhub@gmail.com ORCID iD https://orcid.org/0000-0001-5864-0543

${ }^{2}$ Lecturer, Faculty of Law, Brawijaya University, Malang City, Indonesia, e-mail: prija.djatmika@ub.ac.id ORCID iD https://orcid.org/0000-0002-5259-1522

${ }^{3}$ Lecturer, Faculty of Law, Brawijaya University, Malang City, Indonesia, e-mail: dhiana@ub.ac.id ORCID iD https://orcid.org/0000-0003-2515-9061

${ }^{4}$ Lecturer, Faculty of Law, Brawijaya University, Malang City, Indonesia, e-mail: nurini.aprilianda@ub.ac.id ORCID iD https://orcid.org/000-0003-3956-3081
}

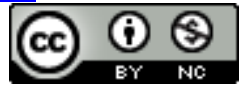

This work is licensed under a Creative Commons Attribution-Non Commercial 4.0 International License. 
The country of Indonesia executed his citizens some time ago, with the execution of the death penalty convicts of Fabianus Tibo, Dominggus Da Silva, and Marinus Riwu on September 21, 2006, for being indicted in the case of Poso riots, Sulawesi. Executed after 2 (two) years since receipt of the notification of the court decision which has a permanent legal force or around 5 (five) years since it was decided by the Palu District Court on April 5, 2001 with Decision No. 459/pid.b/2000/pn.pl. The concerned has submitted a judicial review attempt to the Supreme Court to then apply for a clemency, but was rejected by the President.

Based on the incident the criticism of Indonesia came from various parts of the world and members of Amnesty International in various countries (Supandi, 2008). Likewise, criminal execution of the Bali Bombing I, Amrozi bin H. Nurhasyim, Ali Ghufron and Imam Samudra with a long time of waiting in prison for more than 5 (five) years. Likewise with the Sumiarsih case who committed murder plans in Surabaya against a family with his waiting period in prison for more than 15 (fifteen) years and finally executed. This long time interval provides legal uncertainty to the convicts, such things must be improved so that the implementation of the death penalty is fair for the convicts. The delay in the execution of the execution until the period cannot be determined due to the unclear the legal basis of the time the execution is actually seen as a violation of human rights. The implementation of dead punishment that is delayed without clear reasons and a firm deadline is actually a form of judgment. It can be imagined that in question has been stated by the court that he will be sentenced to death, all the struggles through legal efforts, namely appeal and cassation, a review and clemency have been taken without results. However, when will be executed or run criminal dead, I don't know (Sahetapy, 2007).

The issue of die in Indonesia is also related to its formal law that regulates the implementation of the criminal death after the verdict obtains permanent legal force. The waiting period of the implementation of dead criminal execution is quite time consuming, therefore the existence of a criminal death becomes a phenomenon and becomes widely questioned by various circles about its effectiveness and its relevance to the crime prevention and against the rights of convicts, because the waiting period of convicts for the implementation or execution of death can reach 25 years. Another case example was a criminal execution of death against Kusni Kasdut and Hengki Tupanla in 1980 which awaited more than 25 years before finally executed. The case of Liong Wie Tong and Tan Tian Tjoen in Karawang, the newly dead criminal execution was held in 2009 after being held in prison for 25 years (Arifin, 2009). Problems in Indonesia today regarding protracted dead criminal executions are getting special attention. This happens because of the absence of rules that determine when the time of implementation or criminal execution dies after the court decision that has a permanent legal force.

This condition collides with the rights of convicts or his family to submit extraordinary legal efforts in the form of PK (judicial review) to the Supreme Court and a clemency request to the President. Article 2 Paragraph (3) Law Number 22 Year 2002 concerning Clemasi Mention: "Application for clemency as referred to in paragraph (1) can only be submitted 1 (one) time except in terms of: (a) the convict that has been rejected the request for a climate and has passed 2 (two) years from the date of the clemic application, or (b) convicted which was once given a clemency from a criminal dead became a life imprisonment and had passed 2 (two) years from the date of decision to grant clemency received".

Although submission of clemency is limited to only 1 (one) times with the exception of Article 2 paragraph (3) of Law Number 22 of 2002 concerning the clemency, there needs to be provisions for legislation that regulates the maximum deadline for submission of extraordinary legal efforts in the form of PK (Review) or clemency by convicts from receipt of the notification of court decisions that have permanent legal force, thus the convict also obtained legal certainty about criminal execution imposed on him. The criminal execution of 
death against convicts with the decision of the judge who sentenced him to death since the receipt of the court decision that had permanent legal force and after submitting a judicial review effort until the clemency was rejected by the President. Based on the case as described above, the period of waiting for convicts before being executed is very diverse, and as if there is no certainty. The death penalty convicts has indeed done a crime and causes casualties and suffering. But don't let the country and the community revenue resulting in excessive suffering.

The linkage of legal protection against death penalty convicts that are not immediately executed after permanent legal force, is not only related to the rights of the convict to submit extraordinary legal efforts but also up to clemency. This is one of the original research originality, so that Igin's writer discusses further about the concept of legal protection against death penalty convicts that are not immediately executed after legal force in the future,

\section{Research Method}

The type of research used in this study is normative legal research, which is a research in the form of an inventory of the applicable legislation, to seek the principles of the legislation, so this research seeks to make legal findings that are in accordance with a particular case (Diantha, 2016). The research approaches in this study include the statute approach, the case approach, historical approach, comparative approach, and the philosophical approach. The legal materials used are Primary, Secondary, and Tertiary Legal Materials (Soekanto \& Mamudji, 2011). The legal materials as referred to in succession consist of: Legislative Provisions (ius contitutum and ius constituendum), international provisions such as the UDHR and the ICCPR; Draft Bill on the 2012 Criminal Code, Draft Bill on the 2015 Criminal Code; and most recently the Draft Bill on the 2019 Criminal Code as the ius constituendum; Indonesian dictionaries, English dictionaries, law dictionaries, encyclopedias and legal journals.

The collection of legal materials is carried out using internet searches and literature studies (Marzuki, 2010). All legal materials that have been collected and to make it easier to document the archiving of legal materials are adjusted to their respective groupings. The analysis of the legal material is carried out prescriptive analytically, which aims to produce a prescriptive on what should be the essence of legal research as a legal scientist who is a legal scientist (Setiono, 2004). Guided by the characteristics of legal science as an applied science, the prescriptive provided must be applied as far as possible. The collected legal materials will then be identified by referring to the quality or quality of the data presented.

\section{Results and Discussion}

\subsection{Comparison of power gives clemency in several countries}

The concept of forgiveness in the United States consists of Pardon and Commutation. In this case the office of the Affairs Affairs Lawyer (The Office of the Pardon Attorney) helped the President to carry out the clemency process. Based on the constitution, the power of the President in providing clemency only applies to federal criminal acts. Specifically the provisions in gratification are regulated in the Rules Governing Petitions for Executive Clemency, October 18, 1993, Vol. 58, No. 199, At Pages 53658 and 53659. Generally, clemency can be given based on the good behavior shown by the applicant for a long period of time. In the concept of replacement of punishment in the United States, a change of punishment reduces the period of detention, but does not mean forgiving criminal acts or crimes. Requests for replacement of punishment cannot be made by the convicts that are submitting legal efforts through appeal. In general, changes in punishment are extraordinary forgiveness that is very rarely given. The right reason for considering the change of punishment is the inequality or severity of the punishment that is not supposed to be, critical illnesses that are difficult to cut off or old age. Justice factors can also provide a basis for recommending punishment in certain 
cases context. The amount of time the punishment that has been undertaken and the availability of other legal efforts is very calculated in deciding whether to receive clemency or reject it. The power to forgive is only owned by the President and cannot be canceled by any other government institutions. In this case, a President is more synonymous with a king than elected public officials (Kiger, 2021).

Japan is a country that adheres to a constitutional monarchy system such as Britain and Canada. This limits the power of the Japanese Emperor. As the Head of Seremonial State, the position of the emperor is regulated in the Japanese Constitution as a "state symbol and unifying people". In its history, the concept of forgiveness was given during important empire events, such as the marriage of the crown prince or coronation of the new Emperor. Then based on Article 73 of the Japanese Constitution, the Cabinet has the power to forgive criminals. The Cabinet has also provided forgiveness at imperial families, besides national important events, such as enforcing the post-world war peace agreement in 1952 and the return of Okinawa from the United States in 1972 (Zhang, 2019). Specifically the provisions regarding gratification in Japan are regulated in Pardon Act No. 20 of 1947 (has been changed with ACT No. 49 of 2013) Jo. Ordinance for Enforcement of the Pardon Act (Ministry of Justice Ordinance No. 78 of 1947). The convicted convict can apply for clemency to the National Offenders Commission Rehabilitation Commission (National Office Rehabilitation Commission) through a correctional or prosecutors after a certain period of time and depending on the type of punishment dropped. The Cabinet sets a special criteria for clemency and removes time limits regarding a clemency request.

The concept of forgiveness in the Philippines was carried out by the President. The Philippine President has the power to give a clemency or forgiveness to the inmates of the recommendations of the Board of Pardons and Parole (Board and Parole), he can provide forgiveness, replacement of punishment or suspension of the execution of punishment. Giving clemency by the President is regulated in the Philippine Constitution in Article VII Section 19. The President can provide a suspension or delay, replacement of punishment and forgiveness, and cancel the penalty and ransom, after being decided in the final and binding, except in the case of impeachment (Sugiharto, 2008). The President also has the power to provide amnesty with the majority approval of Congressman. Regarding cases related to violations in elections, the provision of forgiveness by the President must be with the approval of the Constitutional Commission as stated in Article IX Section 5. In carrying out his duties, the President is assisted by a body/council called the parole for forgiveness and liberation (Board of Pardons and Parole) under the Ministry of Justice. Based on Law No. 4103 dated December 5, 1933 and Executive Order No. 83 dated January 11, 1937, the Board was in charge of providing parole and recommended to the President regarding all forms of clemency for someone or prisoners who were entitled to get it. The function of the Board includes conducting studies and reviews and discussions of prisoners who qualify for parole and presidential clemency and review reports submitted by the Parole and Probation Administration and make necessary decisions. During 2008, the Board of Pardons and Parole had handled 4,882 cases of applications, 390 of them the rest of the cases from 2007, 3,073 cases were received in 2008 and 1419 cases for replication requests. 4,528 cases have been resolved for the petition of parole and forgiveness from the president. 21 Cases are returned to the Bureau of Corrections and 7 for serious health cases and seniors delegated to the Presidential Office (Sisanthe, 2010). Then in 2009, the BPP handled approximately 5,056 cases, and disconnected 4,894 cases for petition for parole, suspension of punishment, clemency and including serious health cases and seniors who were delegated to the presidential office.

Whereas in Indonesia, after the amendments to the 1945 Republic of Indonesia, the position of Clemency is increasingly strengthened in the constitution as the highest hierarchy in laws and regulations. Article 14 Paragraph (1) of the Republic of Indonesia State 
Constitution in 1945 stated that, "The President gives clemency and rehabilitation by taking into account the consideration of the Supreme Court". This provision indicates that the President in its functions as a head of state has a prerogative (prerogative) authority to provide clemency and rehabilitation on the basis of the Supreme Court's consideration. The mandate of this constitution was then managed into Law Number 22 of 2002 concerning Clemency (State Gazette of the Republic of Indonesia in 2002 Number 108) which was passed by President Megawati Soekarnoputri on October 22, 2002 in lieu of Law Number 3 of 1950 concerning a clemency application considered not in accordance with the development of the constitution and the needs of the community's law.

On August 20, 2010, President Susilo Bambang Yudhoyono ratified Law Number 5 of 2010 concerning Amendments to Law Number 22 Year 2002 concerning Clemency (State Gazette of the Republic of Indonesia in 2010 Number 100). This change was carried out because of several reasons, one of which was related to the limitations of the time of submitting a clemency application for convicts, namely 1 (one) year after the verdict obtained a permanent legal force as defined by Article 7 paragraph (2). In its development on June 15, 2016, the Constitutional Court through Decision No. 107/PUU-XIII/2015 then annulled Article 7 paragraph (2) which was considered to be able to hurt a sense of justice (sense of justice) for justice seekers (Yustisabel) (Apriani, 2010). This provision is considered to ignore the principles and values of material justice, the principle of legal state that guarantees the basic rights of citizens to fight for justice, and contrary to the concept of legal renewal. Basically, the clemency request submitted by the convict did not delay the implementation of the court's decision, but it was excluded for the death criminal decision as determined by Article 3 Jo. Article 13 of the Clemency Law. Prosecutor as the executor must be able to ensure that the death rights have used their rights, especially the right to apply for a clemency to the President. In this case, the clemency is seen as a remedium ultimum, because if a clemency request submitted by the death penalty convicts was rejected by the President, and the Presidential Decree on the rejection was received by the convict, then the executor was allowed to immediately conduct a criminal execution of death against the concerned death penalty convicts.

\subsection{The Concept Of Legal Protection For Death Penalty Convicts Who Are Not Executed Immediately After Permanent legal force}

The time limit in the provision of a decision on the submission of a review request was explained as follows, a review of the decision that had a permanent legal force (inkracht van gewijsde) was opened after an ordinary legal effort in the form of an appeal or cassation was closed. That is, there are no more ordinary legal efforts that must be passed again or because the deadline for submitting ordinary legal efforts has been exceeded. The court ruling that can be requested by the review is a court ruling at all levels, namely the decision of the first level court (District Court), the decision of the appeal court (High Court) and the decision of the Cassation Level Court (Supreme Court), provided that the decisions in each level have been obtain permanent legal power. If the review institution is faced with a judge's verdict that imposes the criminal dead, there is a legal uncertainty caused by the absence of a time limit for the decision to the ruling petitioned by the death conviction as determined in Article 264 paragraph (3) of the Criminal Code Procedure If viewed from the length of the detention period before the legal status that will still require a few hours. The detention period (waiting period) that can be calculated from the start of the investigation process up to the release of the cassation verdict is for 700 days (23 months 10 days) as predetermined article 24, 25, 27, 28 and 29 of the Caught, even this has not been added with a detention period when the request for review. 
In Article 23 of Law Number 4 of 2004 concerning Judicial Power, (currently Law Number 48 of 2009), regulates definitively regarding the review of the court verdict with permanent legal force. In the article, the review can be made if there are certain things or circumstances. For example, new evidence was found (Novum) and/or a mistake of judges in applying the law (Manalu, Sinambela, \& Manalu, 2010). Special Review submitted by the prosecutor, until now it is still debated by experts, because based on the provisions of the law, specifically in a criminal case, the review request can only be carried out by the convicts or heirs (article 263 paragraph (1) of the Criminal Code Procedure . But until mid-2009, there have been three cases of prosecutors who were accepted and discouraged by the Supreme Court, namely the defendant Pollycarpus Priyanto, Muhdi PR and Syahril Sabirin, in addition to Mukhtar Pakpahan and Natalegawa. With regard to a review, according to the author, it does not inhibit the execution of dies as partly argues.

While the time limit in the administration of the verdict on the submission of the clemency application was explained as follows, the implementation of the clemency before and after the changes in the Constitution in 1945 lies in the need for consideration of the Supreme Court in any request for clemency, with the consideration of the Supreme Court in a period of 30 (thirty) After submitting a request or a copy of the clemency request received by the Supreme Court, it can provide legal certainty to each clemency applicant. The gift of these considerations increases the role of the judicial institution in carrying out a check and balances mechanism, but does not reduce the power of the President.

The consideration of the Supreme Court plays a considerable role in influencing a decision of the presidential clemency. In the period 2004-2010 as data described earlier, there were 191 requests for clemency, which produced 62 presidential decisions, including 51 refuse decisions and $11 \mathrm{Kabul}$ decisions. The clemency decision granted a request from 60 convicts and rejected the request from 131 convicts. The Presidential Decree that takes into account the consideration of the MA numbered 53, while the Presidential Decree that did not follow the consideration of the MA numbered 9, meaning the percentage of the president in terms of taking into account the consideration of the MA of $85.5 \%$. Then the percentage did not pay attention to the consideration of the MA of $14.5 \%$. This shows that the MA consideration is quite influential in a clemency decision making by the President. Article 14 Paragraph (1) of the 1945 Constitution of the 1945 Constitution as the Legal Platform and Check and Balances in terms of implementation are granted or refusing the clemency has been running as (Aryanto, 2011).

The analysis of the provisions of the review can be explained as follows, extraordinary legal efforts (judicialion) can be carried out on court ruling that has permanent legal force. Article 263 paragraph (2) of the Criminal Code Procedure (2). Then Article 263 paragraph (3) of the Criminal Code Procedure (3) determines that on the basis of the same reason as in paragraph (2) of a court ruling that has obtained legal forces can still be submitted a review request if in the decision, an acquired deed is stated to have been proven but not followed by a chance. The right to submit a review of a review of a court ruling that has obtained a permanent legal force is the rights of convicts or heirs as determined by Article 263 paragraph (1) of the Criminal Code Procedure. Based on the explanation of Article 23 of Law Number 4 of 2004, a review can be made if there are certain things or circumstances after the decision is dropped, for example, new evidence (Novum), and/or the mistake of judges in applying the law. When compared with Law Number 19 of 1964, the provisions of Article 21 of Law Number 14 of 1970, finally Law No. 48 of 2009 Increases the provision that the review can be proposed both in the Civil Case and Criminal Congress and Judicialization Submitted to the Court Agung (Anjari, 2015). Especially in a criminal case, the term last review contained in Law Number 8 of 1981 concerning Criminal Code Procedure Law, which is as stipulated in Chapter XVIII, the second part, Article 263 to Article 269 of the Criminal Code Procedureuever. In Article 
263 of the Criminal Code Procedure Code was stated, "against the court ruling that has obtained a permanent legal force, except for free verdict or escape from all lawsuits, convicts or heirs can submit a request for a review of the Supreme Court". After the release of the Criminal Code Procedure Code in 1981, the term review was stretched again in Law Number 14 of 1985 concerning the Supreme Court, as contained in Article 28, Article 34 and Article 66 to Article 77. In addition to Law Number 14 of 1985 it also contained in Article 23 and Article 24 of Law Number 48 of 2009 concerning Judiciality.

While the practice in the trial in Indonesia, a long-known review and enforced. What is meant by a review in Positive Law Indonesia, in some positive laws it is only mentioned that the court ruling that has obtained legal forces can still be requested by the Supreme Court with several requirements. A court decision can be said to have obtained a permanent legal force (Inkracht van Gewijsde), in the law of criminal events that are now valid and in Government Regulation Number 27 of 1983 concerning the Implementation of Criminal Code Procedure, not at all regulating it. But in the decision of the Minister of Justice Number M.14-PW.07.03 of 1983 concerning the Additional Guidelines for Implementation of the Criminal Procecision, it was stated that the decision of the new court was declared to have a permanent legal force if the deadline for thinking was exceeded 7 (seven) days after the first level court decision and 14 (fourteen) days after appeal court ruling.

Doctriner there are two important reasons in submission of judicial review, namely the existence of "Conflict van rechtSpraak" and the existence of "Novum" (Wajayanta, 2014). Conflict van rechtspraak is the existence of different decisions with conditions declared proven, but it turns out that one another is contradictory. Whereas Novum is the existence of a new situation that causes strong allegations, if it is known that the situation at the time of the trial is still ongoing the result will be a free decision or escape the lawsuits or the demands of the public prosecutor cannot be accepted and also the case is applied to lighter criminal provisions.

Analysis of the provisions of clemency is explained as follows, in Indonesia, in accordance with the provisions of Article 14 paragraph (1) of the 1945 Constitution which is subsequently regulated in Law Number 22 of 2002, amended by Law Number 5 of 2010, the President has authority Give clemency after paying attention to the consideration of the Supreme Court. This authority comes from rights attached to the position of the President as Head of State which is generally also owned by the Head of State in other countries. This right is exclusive so it is referred to as prerogative and therefore the consideration of the Supreme Court is not binding even though the procedural side must still be traversed.

Provisions regarding clemency do not determine what crime can or cannot be given clemency so that in principle all convicts can be given clemency. Provisions also do not determine the reasons that can be used by the applicant to apply for a clemency or reason for the President to grant the request.66 In practice, the reason for the application and granting of clemency is not much different from the reason for the remission, namely the conditions and behavior of convicts. The convicted conditions are a humanitarian reason, namely the health of the rally or mentally good convicted, while the reasons for behavior are changes in attitudes and behavior of convict in the more positive direction. This is in accordance with the piercing paradigm that prioritizes more popularity compared to condemnation.

Giving clemency is regulated in Article 14 of the 1945 Constitution which reads, "The President gives clemency, rehabilitation, amnesty and abolition". The article reflects the authority of the President who is independent and absolute. In providing forgiveness, the President does not require approval and consideration from government branches or other institutions. This power is very large and the President has full power to do so. According to the explanation of the 1945 Constitution, in this power the President acted as head of state. Clemasi by the President is basically not a legal action, but a non-legal action based on the prerogative of a head of state, thus gration is forgiveness in the form of reducing criminal 
(starfvermiderend) or creating criminalization or the elimination of the criminalization that has been decided and permanent legal force (Eddyono \& Wagiman, 2007). When referring to the results of the study, there is a difference in the implementation of clemency in Indonesia with the United States and Japan, while the implementation of clemency in the Philippines is almost similar to the practice of implementing clemency in Indonesia. In America, Pardon was given after the convict was finished serving his sentence. The forgiveness was given after the convict through the waiting period of 5 (five) years and institutions that gave recommendations to the President was the office of the clemency attorney (The Office of the Pardon Attorney).

In Japan, clemency or forgiveness is classified as general forgiveness and special forgiveness for certain people and is assessed based on evaluations carried out by the Minister of Justice obtained based on the recommendations provided by the National Offenders Rehabilitation Commission. Public forgiveness can be given to all convicts that commit crimes as specified in the Cabinet command. In the Philippines, the President in giving clemency is assisted by a body or council called the parredons and parole liberation (Boardons and Parole) led by a chairman of the Executive Director and Deputy Executive Director who is under the Ministry of Justice. This council provides recommendations for the President regarding all forms of clemency for a prisoner who has the right to get it. In addition, this council is also tasked with conducting studies and reviews for inmates who are qualified to obtain forgiveness from the President. In each of these countries, submitting a clemency application is handled by the institution responsible for providing recommendations to the President (America and the Philippines) or the Cabinet of Prime Minister (Japan) after fulfilling the requirements and standards of consideration in providing clemency.

Indonesia requires consideration of the Supreme Court, while the implementation of clemency in the United States, Japan and the Philippines is carried out without consideration or interference from the branch of the judicial institution. In other words, America, Japan and the Philippines have a special independent institution that serves to provide recommendations to the head of state in considering clemency. According to the author, in Indonesia the dead criminal decision will result in a criminal execution of death if the internal and extraordinary legal efforts have been taken by the convict but do not meet the expectations as desired, unless there is a presidential intervention that has prerogative rights in its function as a head of state regarding the law or reject the request for clemency proposed by convicts. Article 3 Jo. Article 13 of Law No. 22 of 2002 which has been amended by Law No. 5 of 2010 must be the last gate for the executor of the executor before carrying out the judge's verdict (criminal execution of death). In this case, the state is required to guarantee the right to death rights to submit a clemency has been fulfilled before the relevant facing a firing team.

The concept of a recent review is explained as follows, a review is a filter from the Supreme Court, while clemency is a filter from the President. Without going through alternatives or cumulative from these two filters, the execution of death cannot be carried out by the prosecutor as the executor. The right to apply for a review as an extraordinary legal effort is the first shield for the death penalty convicts in order to change the decision of the court that has obtained legal force remains as an embodiment of the Due Process of Law principle.

The issue arose on the case of convicts that was convicted of dead criminals did not have a time limit when the death penalty convicts submitted an extraordinary legal reinforcement. According to the author, if the death penalty convicts do not propose their rights to make a review effort, then with the transfer of clemency law from previously with Law No. 5 of 2010 concerning clemency (last clemency law), in this case the rights of death rates who do not submit PK can be exceeded directly using their rights to apply for clemency to the President since the court's decision has obtained a permanent legal force (Wantu, 2007). 
While the concept of clemency in the future described as well as the following, criminal plotning, especially with the execution of dead crimes is important in criminal law and criminal justice in Indonesia. Therefore, the process, activities and imposition of decisions must be stipulated wisely, selectively and objectively, and there is no difference in treatment of convicts. Dead criminal plotning is not only to suit the law of the event but also related to justice, the certainty of law and human rights and the objectives of the politics of a country and politics. In the opinion of the author, the request to submit a clemency is the rights of convicts that must be taken and on the other hand refusing and receiving a clemency request is the right of the president constitutionally. If the death penalty convicts does not apply for a clemency, according to the provisions of the Law Number 5 of 2010, "For the benefit of humanitarian and justice, the minister in charge of government affairs in the field of law and human rights can ask the parties to apply for clemency and ministers intended to examine and Carry out the process of submitting clemency by submitting a request to the president who submitted a long time for a period of 1 (one) year after the verdict obtained permanent legal force ". Based on this, the President must provide certainty limits of time, in this case the author argues, which is 10 (ten) years since the verdict in Kracht Van Gewijsde. Therefore, a period of 10 (ten) years according to the author is the ideal time so that the concept of humanistic and equitable conviction.

From this description of the concept of concepts that the author stated, the execution of death against the convicts is expected to no longer be in the waiting period of 10 (ten) years, and also no more under 10 (ten) years. Basic consideration of the Supreme Court to be accepted or refused by the president's clemency, according to the author of the President must truly pay attention to the legal considerations of the Supreme Court intended, if the Supreme Court provides a consideration that the crimes committed by the convicts are very dangerous to the lives of Indonesian people, for example narcotics crimes (convicted as suppliers, Especially as a factory owner), on the basis of the consideration of the Supreme Court to be rejected by his graduation, thus the President must fulfill these considerations, even though the refusal and refusal of clemency is the president's prerogative, because it greatly influences the criminal justice system. Besides that it is also important to pay attention to the objectives of the distribution by balancing between absolute theory and relative theory.

Likewise with the issuance of the Fiat of the President's execution, it is expected that it does not require too long for the prosecutor's office to immediately submit to the President. The application of life sanctions must be the main alternative, after convict waiting for too long execution. But it does not rule out the possibility of dead crimes will continue to be carried out if noting Article 100 paragraph (5) of the 2019 Criminal Code Bill: If during the trial period for 10 (ten) years do not show the attitudes and actions that are commendable and there is no hope to be repaired, then the dead criminal can carried out on the orders of the Attorney General. Likewise in Article 101 of the 2019 Criminal Code Bill, on the contrary if the request for clemency the death penalty convicts rejected and the dead crime was not carried out for 10 (ten) years not because the convict of escaping, the dead criminal can be changed to a life imprisonment with a presidential decision. From the several provisions above, related to the constitutionality of the waiting period execution for the death penalty convicts is clearly not regulated in legislation, but only regulated about several factors that can be justified juridically to delay execution. Outside of this, if there is an obscurity of the waiting period of execution for the death penalty convicts such as cases that have been described in the previous discussion, then it is an unconstitutional thing in the distribution system. That is, this problem is very impact on the enforcement of criminal law in Indonesia, which is not the achievement of the objectives of convicts.

The arrangement of the waiting period for the death penalty convicts that has been permanent legal force, but has not been executed even though the principle is in order to 
provide legal certainty and legal justice in the law enforcement process for convicts. Because, the defendant who was sentenced to death by the court, had to undergo 2 (two) the basic criminal type of one of the same actions, namely the death and imprisonment. The practice of applying such laws caused legal uncertainty, because the convict did not know the criminality being imposed on it. The uncertainty is very detrimental to the seekers of justice (yustisabel). Even though in addition to the principle of justice, the principle of legal certainty is the next goal. Furthermore, the execution of death if it is not immediately implemented, late or protracted, this is a practice that is contrary to the constitution, the law on human rights and the principles of legal protection for victims, convicts and the community. The uncertainty of the waiting day of execution resulted in the absence of legal certainty for convicts. Moreover, for victims and the community feels the lack of justice, it can even bring up the failure of its main judgment objectives in terms of general prevention.

\section{Conclusion}

At the Judicial Review stage, the Criminal Code Procedure must regulate the time limit for submitting a judicial review application since the decision has permanent legal force (inkracht van gewijsde), so the waiting period is not too long (starting from the investigation process until the decision of the Cassation is issued and added to the detention period). when the applicant has not, or will and will not even apply for reconsideration). In the future there must be uniformity regarding the waiting deadline which is regulated in legislation, which is a period of 10 (ten) years, so that the existence and effectiveness of criminal mature as a means of prevention (repression) and repression can be realized.

The execution of the judge's decision that imposes a criminal dead against the convict that submits a request for a review and clemency must be stated, if it passes from the specified waiting deadline, then the death penalty convicts of the status must be determined, whether the execution will be carried out or changed to the punishment of conditional death, life prison or prison for 20 (twenty) years. This concept is useful in providing opportunities for death penalty convictsers to be assessed by their behavior. This is intended so that the process of legal and non-legal efforts carried out by the convicts, especially the death convict, gets certainty time regarding the implementation of the execution of the judge's decision that imposes the criminal dead to realize the value of humanistic justice and human rights protection. So that to the government or the President (executive), in terms of granting or rejecting a clemency application, especially to the death penalty convicts, it is fitting to consider carefully the recommendations of the Supreme Court (Judiciary) and the waiting period that has been undertaken by the death penalty convicts in detention, and the social impact that will be potential arises due to the decision taken by the President, so that the power of the president's judicial possessed, especially in granting or rejecting a clemency application can realize humanistic justice and not only based on political assumptions and pressure alone. 


\section{References}

Anjari, W. (2015). Penjatuhan Pidana Mati Di Indonesia Dalam Perspektif Hak Asasi Manusia. E-Journal Widya Yustisia, 1(2): 107-115. Retrieved from https://media.neliti.com/media/publications/247155-penjatuhan-pidana-mati-diindonesia-dala-dc4b10c5.pdf

Apriani, L.R. (2010). Penerapan Filsafat Pemidanaan Dalam Tindak Pidana Korupsi. Jurnal Yudisia, 3(1), 1-14.

Arifin, Z. (2009). Eksistensi Pengaturan Pidana Mati Dan Pelaksanaannya Dalam Sistem Pidana Di Indonesia. Bandung, Universitas Padjadjaran.

Aryanto, J. (2011). Legitimasi Hukuman Mati Di Indonesia Dalam Kaitannya Dengan Hak Asasi Manusia. Adil Jurnal Hukum, 2(2): 49-56. Retrieved from http://lib.law.ugm.ac.id/ojs/index.php/ajh/article/view/1393

Diantha, I M.P. (2016). Metodologi Penelitian Hukum Normatif Dalam Justifikasi Teori Hukum. Jakarta, Prenada Media Group.

Eddyono, S.P. \& Wagiman, W. (2008). Catatan Atas Penggunaan Pidana Mati Di Indonesia. Jurnal Legislasi Indonesia, 4(4), 89-93.

Kiger, P. J. (2021, May 19). How Presidential Pardons Work. Retrieved from https://people.howstuffworks.com/presidential-pardon.htm

Manalu, L. R., Sinambela, C. T. N., \& Manalu, L. R. (2010). Hukum acara pidana dari segi pembelaan. Jakarta, Indonesia: Novindo Pustaka Mandiri.

Marzuki, P.M. (2010). Penelitian Hukum. Jakarta, Kencana.

Sahetapy, J. E. (2007). Pidana Mati Dalam Negara Pancasila. Bandung, Citra Aditya Bakti.

Sapardjaja, K. E. (2007). Permasalahan Pidana Mati Dewasa Ini Di Indonesia. Jurnal Legislasi Indonesia, 4(4),19-34. Retrieved from https://perpustakaan.kpk.go.id/index.php?p=show_detail\&id=3766.

Setiono, (2004). Rule Of Law (supremasi hukum). Surakarta, Universitas Sebelas Maret.

Sisanthe, J. (2010, December 27). Aquino: Govt reviewing guidelines for executive clemency. GMA News Online. Retrieved from https://www.gmanetwork.com/news/news/nation/209195/aquino-govt-reviewingguidelines-for-executive-clemency/story/, (accessed on 14 December, 2020).

Soekanto, S., \& Mamudji, S. (2011). Penelitian Hukum Normatif Suatu Tinjauan Singkat. Jakarta, Rajawali Pers.

Sugiharto, G. (2008, Desember 25). Sistem Hukum Philipina. Gats_shmh. Retrieved from http://wwwgats.blogspot.com/2008/12/sistem-hukum-philipina.html, (accessed on 24, December, 2020). 
Supandi, H. (2008). Eksistensi Pidana Mati Dalam Proses Penegakan Hukum Di Indonesia. Journal of European Studies, 4(2).

Wajayanta, T. (2014). Asas Kepastian Hukum, Keadilan Dan Kemanfaatan Dalam Kaitannya Dengan Putusan Kepailitan Pengadilan Niaga. Jurnal Dinamika Hukum, 14(2), 216226. http://dx.doi.org/10.20884/1.jdh.2014.14.2.291.

Wantu, F. M. (2007). Antinomi Dalam Penegakan Hukum Oleh Hakim. Mimbar Hukum, 19(3), 387-398. https://doi.org/10.22146/jmh.19070.

Zhang, L. (2019, November 5). In Japan: Pardon System Debated | In Custodia Legis: Law Librarians of Congress. Library of Congress. Retrieved from https://blogs.loc.gov/law/2019/11/in-japan-pardon-system-debated/, (accessed on 24 December, 2020).

\section{Law and Regulation}

Indonesia, 1945 Constitution, retrieved from https://www.dpr.go.id/jdih/uu1945

Indonesia, Palu District Court on April 5, 2001 with Decision No. 459/Pid.B/2000/PN.PL. Retreved from https://hukumanmati.id/api/files/16279756873630giz1grq7ccs.pdf

Indonesia, Law Number 22 Year 2002 concerning Clemasi. Rretrieved form https://pih.kemlu.go.id/files/UU\%20Nomor\%2022\%20Tahun\%202002\%20tentang\% 20Grasi.pdf

Indoneisa, Draft Bill on the 2012 Criminal Code. Rretrieved form https://www.dpr.go.id/dokakd/dokumen/RJ1-20181127-110919-8068.pdf

Indoneisa, Draft Bill on the 2015 Criminal Code. Rretrieved form https://bphn.go.id/data/documents/naskah_akademik_tentang_kuhp_dengan_lampiran . $\mathrm{pdf}$

Indoneisa, Draft Bill on the 2019 Criminal Code. Rretrieved form https://www.dpr.go.id/dokakd/dokumen/RJ1-20181127-110919-8068.pdf

Indonesia, Law no. 5 of 2010 concerning Amendments to Law Number 22 of 2002 concerning Clemency. Rretrieved form https://jdih.bumn.go.id/baca/UU\%20Nomor\%205\%20Tahun\%202010.pdf

Indonesia, Constitutional Court through Decision No. 107/PUU-XIII/2015. Rretrieved form https://mkri.id/public/content/persidangan/putusan/107_PUU-XIII_2015.pdf

Indonesia, UU no. 3 of 1950 concerning Applications for Clemency. Rretrieved form https://peraturan.bpk.go.id/Home/Details/25995/uu-no-3-tahun-1950

Indonesia, Criminal Code Procedure. Rretrieved form https://www.bphn.go.id/data/documents/81uu008.pdf

Indonesia, Law no. 16 of 1964 concerning Principal Provisions Of Judicial Power. Rretrieved form

https://peraturan.bpk.go.id/Home/Download/39618/UU\%20Nomor\%2019\%20Tahun \%201964.pdf

Indonesia, Law no. 14 of 1970 concerning concerning Principal Provisions Of Judicial Power. Rretrieved form https://www.bphn.go.id/data/documents/70uu014.pdf

Indonesia, Law no. 8 of 1981 concerning Criminal Procedure Law. Rretrieved form https://kejari-sukoharjo.go.id/file/643dc5c9e3fac7c6452af27d44d1b5ba.pdf 
Indonesia, Law no. 14 of 1985 concerning Supreme Cour. Rretrieved form https://jdih.kominfo.go.id/produk_hukum/view/id/272/t/undangundang+nomor+14+ta hun+1985+tanggal+30+desember+1985

Japan, Japanese Constitution, Article 73 about the cabinet. Rretrieved form https://japan.kantei.go.jp/constitution_and_government_of_japan/constitution_e.html

Pardon, Legal Authority Governing Executive Clemency. Rretrieved form https://www.justice.gov/pardon/legal-authority-governing-executive-clemency

Philippine, Law No. 4103 dated December 5, 1933. Rretrieved form https://lawyerly.ph/laws/view/13d37

Philippine, Executive Order No. 83, s. 1937. Rretrieved form https://www.officialgazette.gov.ph/1937/01/11/executive-order-no-83-s-1937/

Philippine, Philippine Constitution in Article VII Section 19. Rretrieved form https://www.officialgazette.gov.ph/constitutions/the-1987-constitution-of-therepublic-of-the-philippines/the-1987-constitution-of-the-republic-of-the-philippinesarticle-vii/ 


\title{
ДИСЦИПЛИНАРНА ОТГОВОРНОСТ НА ХАБИЛИТИРАНИТЕ ЛИЦА ЗА НАРУШАВАНЕ НА ТРУДОВАТА ДИСЦИПЛИНА СПОРЕД БЪЛГАРСКОТО ЗАКОНОДАТЕЛСТВО
}

\author{
АНДРИЯНА АНДРЕЕВА 1 \\ DISCIPLINARY RESPONSIBILITY OF HABILITATED PERSONS FOR \\ VIOLATION OF LABOR DISCIPLINE UNDER BULGARIAN LEGISLATION
}

\author{
ANDRIYANA ANDREEVA ${ }^{1}$
}

\begin{abstract}
Резюме
В настоящата работа се изследва въпроса за трудовата дисииплина и дисииплинарната отговорност на хабилитираните лица според българското законодателство. Отговорността в сферата на висшето образование е гаранция за високо качество на образователната услуга и за спазване на правата на обучаваните лица. На правен анализ са подложени нормите на относимите нормативни актове Закон за висшето образование и Закон за развитие на акдемичния състав в Република България. На база на извършеното изследване на някои въпроси на дисииплинарните нарушения и дисциплинарните наказания се правят изводи и обобщения за приложение на нормите.
\end{abstract}

Ключови думи: хабилитирани лица, работодателски контрол, дисциплинарни нарушения, дисциплинарни наказания, трудова дисцииллина

\section{Abstract}

The present work examines the issue of the work discipline and the disciplinary liability of the habilitated persons according to the Bulgarian legislation. The liability in the sphere of higher education is warranty for high quality of the educational service and for observation of the rights of the trained persons. The norms of the relevant normative acts - HEA and DASRBA have been subjected to legal analysis. Based on the examination of some issues of the work discipline breaches and disciplinary sanctions conclusions and summaries for the application of the norms are made.

Keywords: habilitated persons, employer control, work discipline breaches, disciplinary sanctions

JEL Codes: K31

\section{Въведение}

Дисциплинарната отговорност е самостоятелен вид юридическа отговорност, която е предвидена в нормите на трудовото законодателство с цел защита на обществените отношения свързани с престирането на работната сила. Чрез нея се

\footnotetext{
${ }^{1}$ Андрияна Андреева, доктор по право, доцент в Икономически университет - Варна, ръководител катедра „Правни науки“, директор на Център магистърско обучение; Ръководител на Университетски център по медиация; научни интереси: трудово право и обществено осигуряване, нормативна уредба на висшето образование. e-mail: a.andreeva@ue-varna.bg ORCID iDhttps://orcid.org/0000-0001-6632-3695
}

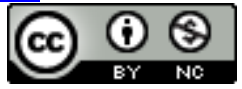

This work is licensed under a Creative Commons Attribution-Non Commercial 4.0 International License. 
санкционират онези деяния, които имат относително ниска степен на обществена опасност, както самостоятелно разгледани, така и съпоставени с аналогичните им видове деяния. Същевременно обаче този вид отговорност е с особена значимост за трудовия процес и за гарантиране на качеството на престираната работна сила. Нейната роля е още по-голяма предвид обезпечаването на такава обществена сфера каквато е висшето образование.

Наименованието дисциплинарна отговорност включва няколко компонента. От една страна отразява характера на правонарушението, а от друга страна е обвързано със спецификата на правно въздействие на трудовото право. За всяка една трудова дейност е от основополагащо значение спазването на установения ред за полагането на труда. Посредством това се гарантира както високо качество на трудовия процес и извличане на ползи за работодателя, така и създаване на безопасни условия за всички работници и служители. С оглед на разнообразието на трудовите дейности, респективно сферите на полагането на труд, съществуват особености, които налагат регулирането им посредством специални норми на национално ниво, както и уредба на локално ниво от отделния работодател. На база на предоставената му работодателска власт той управлява трудовия процес и има предоставена дисциплинарна власт да наказва при нарушения на трудовата дисциплина. В правната теория се застъпва становище, което можем да споделим, че дисциплинарната отговорност на работниците бива:

$>$ обща, отнасяща се до всички категории работници и служители и

$>$ специална, отнасяща се за определени категории работници или осъществявана от специални органи (Милованов, 1988 б). Вторият вид се регулира от норми на специални закони, съдържащи отклонение от режима на КТ.

Висшето образование е сфера с особено значение, предвид което то попада в рамките на нормативното регулиране на специалното административно право. Същевременно една немалка част от въпросите, касаещи трудовите правоотношения на академичния състав, респективно отговорността за нарушаване на трудовата дисциплина са обект на регламентиране от трудовоправните норми.

Актуалността на изследваната тема се свързва със завишените изисквания на обществото спрямо академичния състав предвид изпълнението на възложените функции. Още в по-голяма степен това е относимо спрямо хабилитираните лица, намиращи се на върха на академичната йерархия (Банов, 2018 в).

Предвид протичащите реформи в сферата на висшето образование въпросът за дисциплинарната отговорност на този етап остава извън законодателния интерес, но авторът счита за значимо поставянето му на полето на доктриналните изследвания.

Цел на настоящата разработка е въпроса за трудовата дисциплина и дисциплинарната отговорност на хабилитираните лица в Република България. Отговорността в сферата на висшето образование е гаранция за високо качество на образователната услуга и за спазване на правата на обучаваните лица. На правен анализ са подложени нормите на относимите нормативни актове - Закон за висшето образование (ЗВО) и Закон за развитие на акдемичния състав в Република България (ЗРАСРБ). На база на извършеното изследване на дисциплинарните нарушения и дисциплинарните наказания се правят изводи и обобщения за приложение на нормите.

Настоящата работа съчетава изследователски методи, ползвани в правната доктрина, като нормативен, сравнителноправен, индукция и дедукция.

Авторът поставя органичение в изследването, като се анализират някои въпроси на дисциплинарната отговорност само на хабилитираните лица предимно в нейния материалноправен аспект. Процесуалните въпроси са засегнати в базисни моменти и без претенции за изчерпателност. Материальт е съобразен с националното законодателство към 15 ноември 2021 г. 


\section{1. Трудова дисциплина в сферата на висшето образование}

Трудовата дисциплина в академичните среди е изключително важна, тъй като се явява компонент на сложни взаимовръзки. Наред с класическите трудови отношения, които предполагат взаимодействие между работника или служителя и работодателя, при предоставянето на труд във висшето образование, т.е. за образователния и изследователския процес се наслагват още компоненти (Банов, 2018 а). Членовете на академичния състав са призвани да осигурят високо ниво на предоставяната образователна услуга, респективно качество на провежданите научни изследвания. С оглед на това изискванията, които са заложени спрямо техния труд предполагат към тях да се прилагат завишени критерии за качество на престираната работна сила (Банов, 2018 б), което от своя страна се отразява върху рейтинга на висшето училище, към чийто състав те се числят. Контролът в областта на образователния процес е сложно изграден и единият от базовите компоненти е вътрешният контрол, осъществяван от работодателя - висше училище, спрямо академичния състав. При констатирани нарушения механизмът за реакция както за защита интересите на конкретния работодател, така и на обществения интерес, е дисциплинарната отговорност.

Изясняването на дисциплинарната отговорност на хабилитираните лица е част от комплексния въпрос за отговорността на членовете на академичния състав, тъй като законодателят не е предвидил конкретни норми, които да са приложими само спрямо хабилитирани лица. Този подход считаме за правилен, тъй като именно залагането на високи изисквания на всички йерархични нива в системата на академичния състав егаранция за качеството на висшето образование и научна дейност.

Изясняването на специфичните правни въпроси, свързани с дисциплинарната отговорност в сферата на висшето образование (в т.ч. на хабилитираните лица), изисква анализиране на някои базисни момента, а именно - понятието трудова дисциплина, характер на нарушението, чрез което тя се нарушава и което се явява юридическият факт, водещ до реализиране на отговорността, както и кръга от субекти, спрямо които тя се реализира.

Този подход е обоснован и предвид източниците на дисциплинарна отговорност за хабилитираните лица. Те са комплекс от норми на специалния ЗВО и общия нормативен акт - Кодекс на труда (КТ).

В случая обаче, за разлика от класическия принцип - lex specialis derogat lex generalis, сме в хипотеза на допълване на нормите. Наред с основанията в специалния закон, отразяващи спецификата на трудовата дейност в образователната сфера, спрямо хабилитираните лица действат и нормите на КТ, по аргумент от чл. 59 от ЗВО. Това е така предвид законодателната техника, ползвана при изграждане на института на дисциплинарната отговорност. КТ съдържа комплекс от материални и процесуални норми, обединени в институти, които указват както въпроси, свързани с правонарушението, систематика на видовете, система на наказанията, така и реда за реализиране на отговорността и последиците за субекта на нарушението. С това се дават основите на дисциплинарната отговорност, над която в специалните източници се извършва надграждане, съобразно спецификата на труда, полаган в конкретната сфера, респективно особености на нарушенията, приложими за този кръг работници и служители.

Тази последователност ще бъде следвана и в настоящото изложение, а именно изясняване на основни понятия на дисциплинарната отговорност, над които да бъде извършен и надграден нормативен анализ на актуалните норми в специалния закон. Предвид предмета на изследването общите въпроси ще бъдат представени в базисните 
им параметри, а акцент ще се постави на спецификата на отговорността при членовете на академичния състав в това число и хабилитираните лица.

В обобщение може да се направи извод, че дисциплинарната отговорност на хабилитираните лица:

$>$ е относима към общата отговорност, тъй катопри нея не се проявява действието на изключването (lex specialis derogat generali), приложимо при специалната дисциплинарна отговорност;

$>$ обогатена е с норми, които отразяват спецификата на престирания труд и трудовата функция, осъществявана от членовете на академичния състав;

$>$ прилага се по общият ред на КТ и се реализира от органите, представляващи работодателя.

Трудовата дисциплина и дисциплинарната отговорност е предизвиквала интереса на редица видни български учени, които в свои трудове изследват различни аспекти. Сред тях са Кругер Милованов (1988 б; 1967; 1977), Васил Мръчков (1971), Илия Янулов (1955), Тръпко Танев (1961), Димитьр Киров (1957), Румяна Асланова (1994), Лариса Тодорова (2017), Андрей Александров (2011 a; 2011 б; 2016 a; 2016 б), Владимир Данев (2021), Христо Банов (2020 б, 2020 в) и много други. Анализирането в исторически план на дисциплинарната отговорност като вид юридическа отговорност показва нейното еволюиране, което пряко се влияе от съответния етап от развитието на страната, респективно от развитието на трудовото законодателство (Банов, 2020 а) и специалното законодателство в областта на висшето образование.

В първия период от развитието на българското висше образование от Освобождението до 1944 г. университетските преподаватели имат статут на чиновници (държавни служители) $)^{2}$. Закона за чиновниците и Закона за държавните служители ${ }^{3}$ са относими в уредбата на правоотношенията, които възникват между хабилитираните лица и висшето училище, а в това число и при реализирането на дисциплинарната отговорност. В този период административната власт на министьра на народното просвещение е централизирана и силна и се разпростира и върхудисциплнарното производство в случаите на нарушения от страна на преподавателите.

В периода на социалистическо развитие този правен институт е идеологизиран, натоварен с множество политически аспекти и противопоставян на института в западните (капиталистически държави). В този етап в българското трудово право системата от наказания е и най-многобройна, съпоставена с актуалната нормативна уредба. Въпреки тези критики спрямо доктрината в социалистическия период не може да не се отчете приносьт на учените, работещи в областта на дисциплинарната отговорност за изясняване, както същността на редица понятия, така и за развитието на законодателството.

\footnotetext{
2 В тази посока могат да се откроят текстовете на някои от нормативните актове, където това изрично е посочено: Закона за университета от 1907 г.: „Лицата от университетския персонал, които се назначават от министъра в дисциплинарно отношение се подвеждат под постановленията на Закона за чиновниците“; съгласно Наредба-Закон за висшето търговско училище в гр. Свищов „Д. А. Ценов“ от 1936 г.: „Всички преподаватели и служители във висшето търговско училище се приравняват в права и задължения на държавните служители“; съгласно Закона за Държавното висше училище за финансови и административни науки - София от 1940 г.: „Редовните преподаватели и административните чиновници се считат за държавни служители“.

3 Закон за чиновниците. // ДВ, № 123, 1882; Закон за държавните служители. // ДВ, № 243, 1922.
} 
Изясняването на дисциплинарната отговорност предполага изясняването на няколко понятия, които са взаимосвързани. На първо място сред тях е трудовата дисциплина ${ }^{4}$.

Актуалният анализ на института на трудовата дисциплина по КТ показва, че той е регламентиран с императивни норми на КТ. Субект на задължението за спазване на трудовата дисциплина е работникът или служителят по трудово правоотношение. Понятието се използва от законодателя в няколко аспекта.

На първо място, като съвкупност от задълженията на работника или служителя по трудовото правоотношение (чл. 186 КТ).

На второ място, като подчиненост на работника или служителя на работата (чл. 126, т. 7 КТ), при спазването на които се изпълнява трудовата функция. Това значение на понятието отразява разпоредителните правомощия на работодателя при организация на трудовия процес.

На трето място, трудовата дисциплина отразява начина на изпълнение на трудовата функция (чл. 124 КТ), т.е. това е качествена характеристика на възложеното изпълнение на трудовите задължения. Всеки един от тези компоненти има свое специфично правно съдържание и нюансирана правна уредба (Милованов, 1985) (Милованов, 1988 а)

Понятието трудовата дисциплина е обобщаващо и се конкретизира чрез комплекс от конкретни задължения. Законодателят е поставил нормативната основа чрез общо формулираното задължение за спазване на трудовата дисциплина. От своя страна работодателят извършва допълнителна конкретизация съобразно особеностите и спецификите в конкретното предприятие посредством Правилника за вътрешния трудов ред, както и с нареждания на съответните ръководители на трудовия процес (Андреева \& Йолова, 2010).

Неизпълнението на задължението за спазване на трудовата дисциплина е обвързано със специфичен вид юридическа отговорност, наречена дисииплинарна. Тя е самостоятелен вид юридическа отговорност, която се прилага успоредно с останалите видове отговорност, предвидени от наказателното, административното и гражданското право. Дисциплинарната отговорност е заложена като санкция за виновното неправомерно поведение на работника или служителя по трудово правоотношение, свързано с нарушаване на трудовата дисциплина. Тя се изразява в налагане на предвидените в КТ дисциплинарни наказания и задължение на работника или служителя да претърпи определени неблагоприятни последици. КТ урежда този специфичен вид отговорност, като установява основанието, съдържанието и реда за налагане на дисциплинарните наказания.

Като вид юридическа отговорност дисциплинарната отговорност се характеризира със следните белези: тя е отговорност на работника или служителя за виновно неизпълнение на задължения по трудовото правоотношение; отговорността има личен характер; реализира се от работодателя в рамките на специално дисииплинарно производство.

Дисииплинарната отговорност се свързва с метода на правната принуда (Милованов, 1988 а). При виновно неизпълнение на трудовите задължения възниква

\footnotetext{
${ }^{4}$ В българската правна доктрина в различните периоди няма единомислие на авторите за съдържанието и съотнасянето на елементите. Така например според Кругер Милованов „Правната уредба на трудовата дисциплина обхваща три съставки - уредба на задълженията на работника към предприятието в областта на трудовата дисциплина, уредба на наградите за образцова работа, и уредба на дисциплинарната отговорност на работника“. Вж. Милованов, Кр. Цит . съч., С., 1988, с. 6.
} 
възможността за работодателя да наложи дисииплинарно наказание с цел да се въздейства възпитателно и превъзпитателно спрямо работника или служителя.

За да възникне и да се осъществи успешно дисциплинарната отговорност, е необходимо кумулативно да са налице ${ }^{5}$ няколко предпоставки (Данев, 2021): съществуващо трудово правоотношение, запознаване на работника или служителя с неговитетрудови задължения и установените правила при работодателя - т.е. с трудовата дисциплина, изискване на обяснения, както и в предвидените в чл. 194 от КТ срокове:

1/ установяване на извършено нарушение на трудовата дисциплина,

2/ издаване на мотивирана заповед за налагане на някой от видовете дисциплинарно наказание,

3/ връчване на заповедта за налагане на дисциплинарно наказание.

За разлика от правонарушенията в другите правни отрасли /административно, наказателно право/ законодателят в КТ не дава в завършен вид цялостно легално определение на понятието нарушение на трудовата дисциплина ${ }^{6}$. Обобщавайки основните му качества, може да изведем следното определение - дисиииллинарното нарушение е това деяние /действие или бездействие/, чрез което се нарушават трудовите задължения на работника или служителя /включени в трудовата дисциплина/, извършено е виновно и е наказуемо с дисциплинарно наказание, налагано от работодателя по дисииплинарен ред.

Съгласно чл. 56, ал. 2 и ал. 3 ЗВО в съответствие с принципа на академичната автономия, висшето училище има право в правилник да определя ${ }^{7}$ работното време на членовете на академичния състав, обема и вида на учебните и другите им задължения, условията за тяхното изпълнение, както и да поставя и други допълнителни условия или изисквания. Предвид изложеното, приетият от висшето училище правилник, с който се установяват правила и нормативи за формиране, планиране и отчитане на общата нормативна заетост на академичния състав, е вътрешен акт със задължително по отношение на академичната му общност действие.

Спецификата на работата на преподавателите във висшето училище и различните компоненти, от които се формира общата им нормативна заетост (учебна дейност, учебно-методическа и научноизследователска дейност), обуславят особеностите в организацията на работното време, както и в отчитането и заплащането на труда. В този смисъл, разпоредбите на правилника, касаещи планирането, формирането и реда за отчитане на индивидуалната нормативна заетост на всеки преподавател, както и условията, при които се дължат други допълнителни трудови възнаграждения за отчетената за определен период над норматива дейност, в това число и размерите на тези възнаграждения, имат значението на "вътрешни правила" по смисъла на субсидиарно приложимите чл. 242, чл. 244 КТ, чл. 13, ал. 1, т. 4 и чл. 22, ал. 1 от Наредбата за структурата и организацията на работната заплата. ${ }^{8}$

\footnotetext{
${ }^{5}$ В случаите, когато е приложим КТ, по аргумент от чл. 58а, ал. 2 от 3ВО. По-подробно виж по-долу препратка 246.

6 Чл. 186 от КТ дефинира словосъчетанието „нарушение на трудовата дисциплина”, като въвежда съществен признак - наличие на вина, за определяне на дадено деяние като нарушение на трудовата дисциплина. В този смисъл няма пълно дефиниране на понятието и доктрината го доразвива.

7 „В това се изразява и нормотворческата власт на работодателя като част от управленската му власс“, Данев, В. Правният институт на дисциплинарното наказание според българското трудово право. Дисертационен труд за придобиване на образователната и научна степене „доктор“, Русе, 2021, с.145

8 Решение № 176 от 10.01.2019 г. на ВКС по гр. д. № 3658/2017 г., IV г. о., ГК, докладчик съдията Маргарита Георгиева.
} 
Дисциплинарната отговорност на хабилитираните лица е от категорията обща по вида си отговорност, освен в случай на установяване на други правила от работодателя за установяването й, по аргумент от чл. 58a, ал. 2 от $3 \mathrm{BO}$ и то за нарушения по чл. 58а ал. 1 , но отразява и редица специфики. С оглед на пълнота на изследването ѝ можем да кажем, че тя се характеризира със следните белези:

$>$ тя е израз на държавната принуда;

$>$ вид юридическа отговорност, която се прилага за виновно неизпълнение на задължения произтичащи от трудово правоотношение на хабилитираното лице с висшето училище/ научната организация;

$>$ тя е лична отговорност на хабилитираното лице пред висшето училище/ научната организация;

$>$ налага се с определена цел - да се превъзпита нарушителя на трудовата дисциплина и да се въздейства предупредително и възпитателно върху останалите членове на академичния състав, както и другите работници или служители на висшето училище/ научната организация.

Интерес представлява въпросьт кой е компетентен да реализира дисциплинарната отговорност спрямо ректора, като член на академичния състав, в това число хабилитирано лице и отделно в качеството му на Ректор.

С оглед на реда на възникване на трудовото му правоотношение като ректор, а именно сключване на допълнително споразумение с председателя на Общото събрание на висшето училище след проведени избори, считаме че в тази хипотеза би следвало лицето, подписало трудовия договор от името на висшето училище, да се яви друг орган, оправомощен със закон (Данев, 2021) по смисъла на чл. 192 ал. 1, предл. 3 от КТ. В този случай председателят на ОС ще има дисциплинарната власт спрямо Ректора като хабилитирано лице на основанията, предвидени в 3ВО, а за неуредените случаи - КТ, но когато се прилага КТ, възможните за налагане дисциплинарни наказания са само „забележка“ и „предупреждение за уволнение“. Когато дисциплинарната власт се упражнява спрямо Ректора като представляващ висшето училище, то тогава дисциплинарната власт следва да се реализира само по реда, предвиден в КТ (по аргумент от чл. 59 от КТ), при което ще важи казаното в предходното изречение относно правомощията за ангажиране на дисциплинарна отговорност ${ }^{9}$.

Специалната нормативна уредба на ЗВО е лаконична и съдържа регламентация само в нормата на чл. 58a, ал. 1 3ВО.

\section{2. Дисциплинарни нарушения и наказания}

Субект на нарушението на трудовата дисциплина, съгласно нормата е “член на академичния състав или на останалия персонал на висшето училище“. От тук може да се направи извода, че законодателят не прави деление на хабилитиран и нехабилитиран състав. Следователно за извършването на деянията по чл. 58а, ал. 1 ЗВО хабилитираните лица попадат в групата на първата категория лица, а именно членовете на академичния състав. Те придобиват това си качество от момента на възникване на трудовото правоотношение с висшето училище, респективно то се загубва в момента на неговото прекратяване. Това качество се запазва и лицето може да се яви субект и по всяко време от действието на трудовото правоотношение, включително и когато реално не се престира труд, например по време на почивка, отпуск и др. (Милованов, 1988 a).

\footnotetext{
${ }_{9}^{9}$ Интерес представлява съотнасянето на дисциплинарната отговорност на ректора с отговорността му при нарушаване на договора за управление, сключен между висшето училище и МОН. Този въпрос обаче изслиза от кръга на изследването и ще бъде бект на самостоятелно изследване.
} 
В нормата са посочени дисциплинарни нарушения, които законодателят е счел за такива с висока степен на опасност за трудовата дисциплина и като цяло за образователния и научния процес. Предвид това те са основание за налагане на найтежкото дисциплинарно наказание -уволнение. Като форма на вина деянието следва да бъде извършено виновно, като е възможно да се изпълни и в двете разновидности - пряк или евентуален умисъл. В системата на нарушенията по чл. 58а 3ВО са включени три деяния:

$>$ постави изпитна оценка без да е проведен изпит10;

$>$ изпита и постави оценка на лице, което няма право да се яви на изпит при него;

$>$ издаде документ от името на висшето училище, на негово основно звено и/или филиал, който невярно отразява завършени етапи в обучението на студент, докторант и специализант.

Процедурата за установяване на нарушенията по ал. 1 се определя от Правилника за дейността на висшето училище.

Дисциплинарните наказания се налагат по определен ред (Сталев, 1965).

Член на академичния състав, за който е доказана по установения ред проява на корупция, се уволнява дисциплинарно.

Специалните основания за освобождаване от длъжност на преподавателите във висшите училища по ЗВО не изключват общите основания за прекратяване на трудовото правоотношение по КТ, когато те са осьществени, но за хабилитраните лица важат ограниченията, предвидени в чл. 339 от КТ. Прекратяването на трудовото правоотношение с научните работници (Банов, 2019) се извършва със заповед на ръководителя на научната организация след решение на научния съвет за освобождаването им от длъжност на основанията, предвидени в чл. 58 и чл. 58а от 3ВО, а за неуредени случаи, когато се прилага КТ, важат ограниченията, предвидени в чл. 339 от КТ. При налагане на дисциплинарни наказания за нарушаване на трудовата дисциплина ректорьт действа като представляващ работодателя ${ }^{11}$, но е допустимо да упъномощи длъжностно лице с ръководни функции (Данев, 2021) за провеждане на дисциплинарно производство и налагане на дисциплинарно наказание, по аргумент от чл. 59 ЗВО във връзка с чл. 192 от КТ.

Сроковете за оспорване от страна на наказаното лице на наложено дисциплинарно наказание са посочени в чл. 358 , ал. 1, т. 1 и т. 2 КТ - 2 месеца за наложено дисциплинарно наказание „уволнение“ и „предупреждение за уволнение“ и 1 месец за наложено дисциплинарно наказание „забележка“.

Споровете се разрешават от Районния съд по избор на наказаното лице - там където е мястото на работа на служителя или по адрес на седалището на ВУЗ/ научната организация в особена процедура по чл. 310 от ГПК, наричана „Бързо производство“ чрез изготвяне на нарочен документ, именуван „искова молба“ със съдържание предвидено в чл. 127 от ГПК, насочена срещу работодателя. Решението на Районен съд подлежи на обжалване от страната, която не е доволна от решението, пред съответния местно компетентен Окрьжен съд, чието решение подлежи на обжалване пред трета, последна инстанция само по спорове за отмяна на наложеното най-тежко дисциплинарно наказание „уволнение“, а за останалите видове наказания, решението на ОС е окончателно ( чл. 280, ал. 1, т. 3 от ГПК).

От особено доктринално значение за изложението по настоящия раздел е обсъждане на два важни въпроса със съществено практическо приложение възможността работодателят по свой почин да отмени издадена от него заповед за

\footnotetext{
${ }^{10}$ Вж. Ппределение № 1579 от 1.04.2014 г. на Административен съд - София по адм. д. № 3185/2014 г.

${ }^{11}$ В този смисъл: Решение № 9593 от 19.07.2017 г. по адм. д. № 8312/2016 г., VII отд. на ВАС.
} 
налагане на дисциплинарно наказание (чл. 344, ал. 2 от КТ) и възможността за иницииране на производство по медиация.

Първият въпрос, свързан с възможността за отмяна на издадена заповед за налагане на дисциплинарно наказание уволнение, не е бил предмет на обсъждане от съществуващата до 2021 г. доктрина, като достойно внимание й е обърнато от д-р В. Данев в неговия дисертационен труд „Правният институт на дисииплинарното наказание според българското трудово право“ (стр.199-201), както и в изготвен от него доклад (Данев, 2020). Според цитирания автор, освен отмяна на наложено дисциплинарно наказание „уволнение“, е допустимо да се отменят и по-леки наложени дисциплинарни наказания, което гледище се споделя от автора надисертацията.

В контекста на обсъдената възможност подобно действие от страна на работодателя може да е мотивирано от различни обстоятелства:

- $\quad$ когато се установи, че по време на провеждане на дисциплинарното производство са били допуснати пропуски;

- след издаване на заповедта се открият нови обстоятелства, от

съществено значение за ангажиране на дисциплинарната отговорност на служителя;

- $\quad$ работодателят прецени, че наложеното от него наказание е несъотносимо на извършеното нарушение;

- $\quad$ работодателят има нужда от съответния служител, порадивременна липса на друг служител, който да изпълнява тази функция.

Отмяната на заповед за наложено дисциплинарно наказание може да изхожда от личната инициатива на дисциплинарния орган или с оглед на подадена молба / искане / жалба от служителя.

За отмяна на издадена заповед за налагане на дисциплинарно наказание може да се говори само след връчена на служителя заповед, тъй като преди това този документ не произвежда ефект в правната сфера на служителя.

Срокът за отмяна на заповедта е до момента, в който служителят оспори заповедта пред съд.

Отмяната на заповед за налагане на дисциплинарно наказание следва да се извърши с нова заповед, която трябва да бъде връчена на служителя, за да произведе своето правно действие.

\section{Заключение}

В резултат на проведеното изследване на дисциплинарната отговорност на хабилитираните лица според актуалното българско законодателство могат да бъдат направени някои изводи и обобщения.

Дисциплинарната отговорност по своя характер има белезите на общата отговорност за нарушаване на трудовата дисциплина по КТ, но отразявайки спецификите на специалната образователна дейност, се отличава и с редица особености.

Трудовата дисциплина за хабилитираните лица, като част от академичния състав на висшето училище (научна организация) се явява комплексно понятие, което същетава наред с традиционните изисквания заложени спрямо работниците и служителите по общия закон и завишените образователни и научноизследователски изисквания, като специфични за висшето образование. В този смисъл наред с националните норми, важен източник се явяват вътрешните актове на висшите училища (научни организации), в които са заложени конкретни норми в съответствие с принципа на академичната автономия.

$>\quad$ В уредбата на дисциплинарната отговорност законодателят е съобразил от една страна целта на дисциплинарното наказание по общия ред с високите изисквания, 
които се поставят спрямо хабилитираните лица предвид дейността, която те извършват. Въпреки, че целта не е изрично посочена нито в общия, нито в специалните актове тя се извлича от общия анализ на приложимите норми.

Дисциплинарните нарушения по специалните източници са съобразени с осъществяваната образователна дейност и отразяват различните етапи на преподавателския процес. 


\section{Литература (References)}

Александров, А. (2011 а). Материалноправни въпроси на дисциплинарната отговорност с важно практическо значение. Труд и право, 2, 11-18 [Aleksandrov, A. (2011 a). Materialnopravni vaprosi na distsiplinarnata otgovornost s vazhno praktichesko znachenie. Trud i pravo, 2, 11-18].

Александров, А. (2011 б). Практически проблеми на дисциплинарното производство. Труд и право, 2011, 3, 19-26 [Aleksandrov, A. (2011 b). Prakticheski problemi na distsiplinarnoto proizvodstvo. Trud i pravo, 3, 19-26].

Александров, А. (2016 а). Практически проблеми на трудовото право, свързани с дисциплинарната и имуществената отговорност на работника или служителя.

Труд и право, 5, 5-12 [Aleksandrov, A. (2016 a). Prakticheski problemi na trudovoto pravo, svarzani s distsiplinarnata i imushtestvenata otgovornost na rabotnika ili sluzhitelya. Trud i pravo, 5, 5-12].

Александров, А. (2016 б). Съдебен контрол върху законността на дисциплинарното уволнение. Труд и осигуряване, 10(141), 2-9 [Aleksandrov, A. (2016 b). Sadeben kontrol varhu zakonnostta na distsiplinarnoto uvolnenie. Trud i osiguryavane, 10(141), 2-9].

Андреева, А., \& Йолова, Г. (2010). Юридическа отговорност и контрол за спазване на трудовото и осигурително законодателство. Изд. Цани Калянджиев, ИУВарна [Andreeva, A., \& Yolova, G. (2010). Yuridicheska otgovornost i kontrol za spazvane na trudovoto i osiguritelno zakonodatelstvo. Izd. Tsani Kalyandzhiev, IUVarna].

Асланова, Р. (1994). Дисциилинарна отговорност на работника и служителя по Кодекса на труда. Дикта-интелект, С. [Aslanova, R. (1994). Distsiplinarna otgovornost na rabotnika i sluzhitelya po Kodeksa na truda, Dikta-intelekt, Sofia].

Банов, X. (2018 а). Довършване на откритите процедури за придобиване на научни степени след промените от април 2018 г. в Закона за развитието на академичния състав в Република България. Норма, 4, 64-88 [Banov, H. (2018 a). Dovarshvane na otkritite protseduri za pridobivane na nauchni stepeni sled promenite ot april 2018 g. v Zakona za razvitieto na akademichniya sastav v Republika Balgariya. Norma, 4, 64-88].

Банов, X. (2018 б). Същност на промените от 2018 г. в правната уредба на развитието на академичния състав и тяхното значение за довършването на откритите процедури за придобиване на научни степени и за заемане на академични длъжности. Законодателството за академичното развитие в Република България (с. 67-146). София: Институт за държавата и правото - Българска академия на науките [Banov, H. (2018 b). Sashtnost na promenite ot 2018 g. v pravnata uredba na razvitieto na akademichniya sastav i tyahnoto znachenie za dovarshvaneto na otkritite protseduri za pridobivane na nauchni stepeni i za zaemane na akademichni dlazhnosti. Zakonodatelstvoto za akademichnoto razvitie v Republika Balgariya (67-146). Sofiya: Institut za darzhavata i pravoto - Balgarska akademiya na naukite]. 
Банов, X. (2018 в). Същност на промените от април 2018 г. в Закона за развитието на академичния състав в Република България и тяхното значение за довършването на откритите процедури за заемане на академични длъжности. Общество $u$ право, 4, 29-47 [Banov, H. (2018 c). Sashtnost na promenite ot april 2018 g. v Zakona za razvitieto na akademichniya sastav v Republika Balgariya i tyahnoto znachenie za dovarshvaneto na otkritite protseduri za zaemane na akademichni dlazhnosti. Obshtestvo i pravo, 4, 29-47].

Банов, X. (2019). Правни проблеми при заемането на академичните длъжности в Българската академия на науките. Общество и право, 4, 44-67 [Banov, H. (2019). Pravni problemi pri zaemaneto na akademichnite dlazhnosti v Balgarskata akademiya na naukite. Obshtestvo i pravo, 2019, 4, 44-67].

Банов, Х. (2020 а). Историческо развитие на индивидуалните субективни трудови права в българското право. Защита за индивидуалните субективни трудови права (на работника или служителя) (с. 59-83). Варна: Наука и икономика Икономически университет - Варна [Banov, Н. (2020 a). Istorichesko razvitie na individualnite subektivni trudovi prava $\mathrm{v}$ balgarskoto pravo. Zashtita za individualnite subektivni trudovi prava (na rabotnika ili sluzhitelya) (59-83). Varna: Nauka i ikonomika - Ikonomicheski universitet - Varna].

Банов, Х. (2020 б). Развитието на академичния състав и проблемите от извънредното положение. София: Лекс [Banov, H. (2020 b). Razvitieto na akademichniya sastav i problemite ot izvanrednoto polozhenie. Sofia: Leks].

Банов, Х. (2020 в). Трудов договор за обучение по време на работа. Изд. Нова звезда [Banov, H. (2020 c). Trudov dogovor za obuchenie po vreme na rabota. Sofia: Nova zvezda, 2020].

Данев, В. (2021). Правният институт на дисциплинарното наказание според българското трудово право (Дисертационен труд, Русенски университет „Ангел Кънчев“), стр.184 - 199 [Danev.V. (2021). Pravniyat institut na distsiplinarnoto nakazanie spored balgarskoto trudovo pravo (Disertatsionen trud, Rusenski universitet „Angel Kanchev“), str.184 - 199].

Данев, В. (2020). Институтьт на отмяна на заповед за налагане на дисциплинарно наказание уволнение според Кодекса на труда. Правото и бизнесът в съвременното общество, 126-135. Варна, България: Наука и икономика при ИУ- Варна [Danev, V. (2020). Institutat na otmyana na zapoved za nalagane na distsiplinarno nakazanie uvolnenie spored Kodeksa na truda. Pravoto i biznesat $v$ savremennoto obshtestvo, 126-135. Varna: Nauka i ikonomika“ pri IU- Varna].

Киров, Д. (1957). Социалистическа трудова дисцииллина. Профиздат, София [Kirov, D. (1957). Sotsialisticheska trudova distsiplina. Profizdat, Sofia].

Милованов, Кр. (1967). Дисичилинарно уволнение. Наука и изкуство, София [Milovanov, Kr. (1967). Distsiplinarno uvolnenie. Nauka i izkustvo, Sofia]. 
Милованов, Кр. (1977). Правни средства за укрепване на трудовата дисциплина.

Наука и изкуство, София [Milovanov, Kr. (1977). Pravni sredstva za ukrepvane na trudovata distsiplina. Nauka i izkustvo, Sofia].

Милованов, К. (1985). Трудовата дисииплина като задължение по трудовото правоотношение. БАН, София [Milovanov, К. (1985). Trudovata distsiplina kato zadalzhenie po trudovoto pravootnoshenie. Sofia: BAN].

Милованов, К. (1988 а). Трудово право, Част I. НИИПП Г. Димитров, София [Milovanov, K. (1988 a). Trudovo pravo. Chast I. NIIPP “G. Dimitrov”, Sofia].

Милованов, Кр. (1988 б). Дисииплинарна отговорност. Профиздат [Milovanov, Kr. (1988 b). Distsiplinarna otgovornost. Profizdat].

Мръчков, В. (1971). Правна защита срещу неправилно уволнение. Българска академия на науките, София [Mrachkov, V. (1971). Pravna zashtita sreshtu nepravilno uvolnenie. Balgarska akademiya na naukite, Sofia].

Сталев, Ж. (1965). Производството, като динамичен фактически състав. Годишник на CY, 56(2), 109-154 [Stalev, Zh. (1965). Proizvodstvoto, kato dinamichen fakticheski sastav. God. Na SU, 56(2), 109-154].

Танев, Тр. (1961). Нарушения на трудовата дисииплина и дисичилинарни наказания. Профиздат - Издателство на ЦС на профсьюзите, София [Tanev, Tr. (1961). Narusheniya na trudovata distsiplina i distsiplinarni nakazaniya. Profizdat Izdatelstvo na TSS na profsayuzite, Sofia].

Тодорова, Л. (2017). Защита правата на работодателя от назначението до уволнението. Второ преработено и допълнено издание, Cофия [Todorova, L. (2017). Zashtita pravata na rabotodatelya ot naznachenieto do uvolnenieto. Vtoro preraboteno i dopalneno izdanie, Sofia].

Янулов, И. (1955). Социалистическа дисциплина и самодисциплина на труда, Българска академия на науките, София. [Yanulov, I. (1955). Sotsialisticheska distsiplina $i$ samodistsiplina na truda. Balgarska akademiya na naukite, Sofia]. 


\title{
ACTIVE POLICIES AT THE EUROPEAN LABOUR MARKET DURING THE COVID-19 PANDEMIC
}

\section{MARIANA DIMITROVA ${ }^{1}$}

\begin{abstract}
The Covid-19 pandemic has shown European economies that they need a clear plan for the future with a focus on labour market needs. The crisis has significantly affected certain groups of the population and employers in specific types of sectors. The existence of a flexible system of active employment policies and the possibility for the implementation of innovative projects and measures is a prerequisite for successful assistance to the most affected persons and enterprises. The paper presents good practices and successful approaches in the pandemic situation, examines innovations of public employment services and programs for active support of employed and unemployed people in the EU.
\end{abstract}

Keywords: active labour market policies, employment, unemployment, Covid-19 and labour market

JEL Codes: J68, J08, J21

\section{Introduction}

The present paper examines the experience of EU member states in solving labour market problems during the COVID 19 pandemic through the use of active labour market policies. A more successful recovery of labour markets in the EU depends on taking swift and adequate measures to support all those affected by the labour market. Adherence to policies that provide systematic and strong support in priority areas is the basis for the rapid recovery of the EU economy and employment in the short and long term.

The paper regards good practices of European countries for active employment policies. Beside the immediate goals persued by these policies, they have also tended to support the recovery of economies and the implementation of social protection for vulnerable groups of the working population. As there will be maybe at least one more year left to the end of the pandemic, in order for each Member State's national labour market policy to be more successful, it should definetly meet certain conditions. For example, they will have to target vulnerable groups, to anticipate changes in the model of communication and management of active employment programs, to focus on the long-term needs of the labour market, to anticipate the changes in knowledge and skills that will be needed in the labour market after the end of the pandemic. The expected inflation, caused by rising gas and electricity prices, is putting the EU countries to the test. It is certainly a serious reason for the deepening of the crisis, for a higher unemployment and a precondition for impoverishing the population.

On May 25, 2021 the European Commission published specific recommendations on the policies of EU member states in relation to the Covid-19 crisis, three of which are directly relevant to the labour market (European Semester: Recommendations, 2020):

Preservation of jobs by supporting workers affected by the crisis;

\footnotetext{
${ }^{1}$ New Bulgarian University, Chief Assist. Prof. Mariana Dimitrova, Ph.D., Department of Administration and Management, e-mail: m.dimitrova@nbu.bg ORCID iDhttps://orcid.org/0000-0002-9389-3893
}

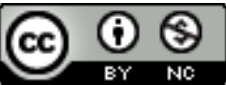

This work is licensed under a Creative Commons Attribution-Non Commercial 4.0 International License. 
Investing in people and their skills;

Support to the corporate sector (especially small and medium enterprises).

In times of crisis, keeping within the above priorities requires a serious rethinking of active labour market policies so that to ensure their maximum impact and the use of public funds in the best possible way. According to Chiodi (2020), the scale of the crisis requires radical changes to ensure the effectiveness of labour market policies through two reforms: a substantial increase in investment and the adoption of an organic design to comprehensively address the labour market's variable structure.

The report of the Organisation for Economic Cooperation "Designing active labour market policies for recovery" (OECD, 2021) sees the active labour market policies as a tool to assist the sustainable and equitable recovery from the COVID 19 crisis. Attention is paid to the right balance of measures aimed at the most at-risk groups and the administrative capacity of labour offices to implement them.

\section{Active labor market policies in European countries during the pandemic}

Since the beginning of the Covid-19 pandemic in 2020 the approach of European countries in the labour market to tackling emerging problems has been anything but a passive wait for the crisis to pass. At the beginning of the pandemic, the active labour market policies played a significant role in job retention, and mitigating the negative effects on loss of income through job retention and subsidy schemes during lock-down periods. The measures have gradually been transformed from temporary to future recovery and they are putting increasing emphasis on the qualification of human capital and the preparation of European countries for the transformations expected after the end of the pandemic.

The European Union is introducing various instruments to combat the economic consequences of the pandemic and to support employment and reduce unemployment. In April 2020 the European Commission has announced the SURE measure (European Commission 2020), which aims at providing temporary support to reduce the risk of unemployment. Guarantee loans have been provided by Member States to support short-term employment schemes and support the self-employed during a pandemic. This type of funding supports human capital in the situation of unemployment and loss of income.

The European Commission is a key player in stimulating the implementation of active labour market policies by requiring such policies to be an integral part of Member States' recovery and development plans for the period 2021-2027. This enables each country to rethink its strategy for overcoming the crisis and to propose long-term political actions to mitigate its negative consequences. The funds provided for in the financial framework amount to some 672.5 billion EUR for curbing the effects of the pandemic. Investment in skills to transform human capital in the Member States supports the digital and green transition. The paper provides examples of the already approved plans in this direction.

The Covid crisis has shown that new skills are needed in the labour markets. In this context, the new European Skills Agenda 2020 has been developed. It focuses on the development of human capital skills through a drastic increase in investment in learning, training and retraining in response to the needs of employers in the labour market and lifelong learning. A key moment that distinguishes it from the 2016 program is the intent to achive compliance between the skills of the human resources, the requirements of the workplaces and the right of education and lifelong learning.

In a recommendation by the European Commission of the 4th of March 2021 on an effective active support to employment following the COVID-19 crisis, attention is drawn to the shift in measures from temporary to job retention to long-term digital economy and green transition to address the longer-term problems of pandemic recovery (Effective active support to employment following the COVID-19 crisis (EASE), 2021)(Commission Recommendation 
(EU) 2021/402 of 4 March 2021). This approach is called "Effective Active Support to Employment" or "'EASE" by its acronym. The period of recovery of the EU economy should include job creation, encourage the development of new skills and support labour market transitions. It is proposed to explicitly include the EASE measures in the recovery and development plans of the EU member countries.

In order for these measures to be successfully integrated, it is important to examine the good practices from the EU Member States. This is done by a study conducted by the European Training Foundation (European Training Foundation, 2021). The report on study presents the innovative practices for ALMPs during the pandemic. At the same time, innovative measures and measures focused on resolving the Covid-19 crisis have been included. The scope of the study is much broader to include just these groups of affected persons who do not register with the labour offices, as well as the established support funds and the innovative active policies that combine more than one measure. An important area of innovation are the services provided by pandemic employment offices, which are undergoing major transformations.

\section{Consequences of the crisis in the eu labour markets}

The crisis caused by COVID-19 has many devastating consequences for the EU and the Eurozone. In addition to the job cuts, it has an impact on reduced economic activity caused by measures to shut down by force temporaly entire sectors of the economy. Unlike previous crises, those who have lost their jobs cannot find another job and have just to stay at home. The fear of infecting the children in those households who have young children either attending school or kindergarten are also barriers to the economic activity.

From a macroeconomic point of view, a higher share of inactive people in the economy at the expense of lower reported unemployment is not such a serious problem. However, the problems of people without income due to the COVID 19 pandemic became exuberant and larger in number in the months of forced inactivity and led to chain and side effects. It turns out that the statistics on employment and unemployment with their available set of definitions and indicators are not enough. The emergence of the crisis has stimulated the appearance of a new approach to the reporting and coverage of people in need.

In the past two years, the improvement of labour market performance in the EU follows the removal of restrictions imposed to combat the pandemic. With each easing of measures against COVID19, the European economies are growing and improving their national labour market performance. The employment in the quarters, when the number of COVID 19 patients decreases and the restriction measures are being levied, is restored to levels close to, but still lower than the pre-crisis levels of 2019. These facts suggest that it is the success to overcome the health crisis that can help the economies and, consequently, the labour markets to recover. The improvement of employment and unemployment indicators in the EU in 2021 softer restrictive measures can also be taken into account compared to the previous year.

The employment at the end of the second quarter of 2021 in the EU was at the average level of $72.7 \%$, and for the same quarter of 2020 it is $71.6 \%$, while in 2019 it was recorded to be $73.2 \%$ (Eurostat, 2021). The officially reported unemployment in the EU for 2019 had been $6.7 \%$ and for 2020 became as high as $7.1 \%$.

Similarly, in 2020 the EU reported a reduction in tax and social security revenues. Absences from work due to reasons other than rest and leave were increasing. In the fourth quarter of 2019 as per data available from Eurostat, some 18.1 million people were absent from work, while only in the second quarter of 2020 they increased to 35.3 million people (Eurostat, 2021). Absences from work has increased enormously in the category of "other reasons" and unplanned absences, which makes it difficult for the companies to respond adequately and ensure a smooth work process. 
The crisis has brought the ordinary people to yet another choice that should not usually face - a compromise, a trade-ff between one's own healthearn income from work. This compromise, this trade-off affects people who generally work in poor conditions, or under flexible employment contracts, or in areas and businesses that are generally not preferred as employment opportunities. And while professionals with better quality jobs have had the opportunity to work remotely according to data from some European studies (Telework in the EU before and after the COVID-19: where we were, where we head to 2020), the problems for all other jobs are getting worse.

The crisis has hit most hardly the young people between the age of 15 to 24 , for whom delaying the start of their first job can have extremely negative consequences in the long run. Youth unemployment in the EU increased three times more between the first and third quarters of 2020. comared to the general unemployment rate. The lack of an adequate policy for young people can lead to a high price to pay in the future. All disadvantaged groups in the labour market have also been severely affected, such as: women, older workers, members of ethnic minorities, migrant workers, the self-employed, people with atypical employment contracts, the long-term unemployed, people with disabilities and others. (Commission Recommendation (EU) 2021/402 of 4 March 2021).

In regard to employment in the separate economic sectors, Eurostat has reported the strongest fluctuations in the number of people employed in the accommodation and catering sectors, which is logically linked to the highest redundancies in these sectors. Another problem is the reorientation of workers to other areas of economic activity and to other sectors of increased demand. Among the seriously affected by the crisis are the persons working in the field of culture and the arts. In 2020, in comparison to 2019, the number of the persons employed in the sector of culture in the EU decreased by 195,000 or in percentage almost twice, i.e. $2.6 \%$ compared to the percentage decrease of $1.3 \%$ in the overall European employment rate (Eurostat Culture statistics - cultural employment, 2021).

The crisis is affecting European countries and their labour markets in a different way. It certainly deepens the problems that have already been part of their development and leads in more rapid pace to the restructuring of the employment in the economies. And this, for sure will have an effect on their long-term development.

\section{The role of the employment services in ensuring active labour market policies and flexible online support}

Each crisis reveals weaknesses in the administrative capacity of the public employment services. At the beginning of the COVID 19 pandemic in 2020, there were difficulties in providing services to users caused by the lockdowns and the social distancing measures. In such a situation, the most visible difficulty is the aggravation of the problems related to ptoviding of public services to an increasing number of citizens and the pressure for ensuring the necessary quality and precision. In addition to increasing the number of people using the employment services, the economic crisis resulting from the COVID 19 pandemic brings alongside the problems of identifying those citizens and companies that need the most support. Lack of response time, high volume of applications and reduced control are prerequisites for omissions and insufficient focus on the most affected groups and individuals.

Being under pressure to rapidly reallocate resources, about two-thirds of countries regarded in an OECD study have been adapting already existing employment policies and programs (OECD Employment Outlook 2021: Navigating the COVID-19 Crisis and Recovery.). About $42 \%$ of countries undertake to rehave reduced social security contributions for all or some employers in order to protect jobs from closure. Some $31 \%$ of them increase their public sector outreach programs, and 22 countries have changed their existing programmes in this regard or have strengthened their own business start-up programs. 
In the same survey, $65 \%$ of respondents from the surveyed countries confirmed that they had increased the budget of public employment services in 2020. Just over half of the respondents $(53 \%)$ have planed such an increase for 2021.

As a rapid response is needed in the context of the economic crisis, this is often linked to the impossibility of a serious transformation of existing programs. However, one possible measure is to focus them better on beneficiaries, who are among the most affected groups in the labour market. States are working in this direction, giving priority to young people, people with disabilities and the long-term unemployed and other vulnerable groups.

The COVID 19 crisis has also led to an unprecedented increase in the use of electronic services - something that was considered important before, but has now taken on different meanings. The most successful are those labour offices where e-services and e-services are available before the pandemic.

A negative finding made by the Organization for Economic Co-operation and Development was that the pople who were most in need of labour offices' services in the COVID 19 pandemic were in fact the ones in least contact with them. The problem of communication with public employment services is not new, but it creates obstacles to receiving targeted and consistent assistance from those most in need. Unfortunately, most of the representatives of the most vulnerable groups do not actively participate in the labour market or do not have the habits and desire to communicate with public employment services. This is the case with young people who traditionally do not have information about PES role and prefer to look for work on their own. At the same time, the share of young people (aged 15 and over) in the total number of those seeking help remains very low and insufficient - $34 \%$ in 2020. According to the OECD data for 2020 in Europe and Turkey, nearly $41 \%$ of the unemployed persons have sought the assistance of the labour offices to find emplyment. And this percentage is even slightly lower incomparison to the one for 2019 which is $45 \%$.

\section{Active labour market policies during the covid 19 pandemic in european countries}

The main priority of the European Commission since the beginning of the COVID 19 pandemic have been the preservation of jobs and the health of workers. In order to achieve this priority, all the instruments available to the European institutions for implementing of the European employment policy have been used. In general, Member States' policies focus on the most vulnerable groups in the crisis, as well as on avoiding mass redundancies. Recovery and resilience plans, which have a time horizon until 2026 are the most important long-term policy document in which active labour market policies are requested. Here, one can point two brief examples, including active labour market policies of approved plans, as well as already implemented active labour market policies in connection with the pandemic.

The approach that the European Commission will follow in drawing up recovery and development plans within the framework of the "NextgenerationEU" and all funds offering funding for human capital programs and measures will be the already mntioned "EASE" approach. It can be used to develop packages of measures that include active labour market policies in three interrelated directions:

- $\quad$ hiring incentives and entrepreneurial support (apprenticeship support, starting your own business, etc.);

- upskilling and reskilling opportunities (vocational training at sectoral and individual level);

- $\quad$ enhanced support by employment services (increasing the capacity of labour offices for targeted and effective support). 
Specific examples can be given with the already approved recovery and development plans of Spain and Greece, in which the provision of funds follows the mechanism of approval of recovery and resilience plans and is based on pre-set criteria. A concrete example can be given by the already approved plan of Spain, which includes measures to support the acquisition of digital skills with an investment of 3.6 billion euros. They will spend on qualification, digital transformation of the educational system and training of specialists in information and communication technologies.

Funds are provided to combat labour market segmentation and to modernize active labour market policies worth of 2.4 billion euros, which include reducing the use of temporary employment contracts, providing individual support to jobseekers through the digitalisation of labour offices, and providing of training opportunities and initiatives for better employment.

Regarding professional qualifications, some 2 billion euros are being provided for retraining and additional qualifications for 135,000 new trainings.

In the Greek recovery and resilience plan, somw740 milion euros are earmarked for employment and social inclusion. Measures are envisaged to strengthen and redesign active labour market policies to increase full-time employment, including the long-term unemployed and people from disadvantaged groups, refugees and Roma. The European Commission has already approved the financing of the plan allocated for grants of 17.8 million euros and loans of 12.7 million euros for the period 2021-2026.

Apart from the level of strategic planning and policy design at the state level, ALMPs are mostly important for the effect they generate in their implementation in specific circumstances and at the local level. The database of the European Foundation for the Improvement of Working and Living Conditions entitled "Policy Watch" (Eurofound, 2021) contains information on active labour market policies undertaken by type of measure and by country in relation to Covid-19. The measures are divided into three major groups: for business, for workers, and for citizens. Out of a total of 1428 published measures in the database, most have been aimed at supproting businesses. These measures include support of the businesses to stay afloat (439), ensuring business continuity and support for essential services (114), reorientation of business activities (76) and supporting businesses to get back to normal (54). Measures aimed at ensuring healthy and safe working conditions, the organization of work, providing work at a distance and preserving jobs predominate in enterprises. In about a one third of the measures, the social partners took part in the development.

The current policies for the last 2 years, showing the use of active labour market policies in the Member States, have been supported by the EU Employment Services Network (European Commission Employment, Social Affairs \& Inclusion 2021). In this database there are published practices that meet certain criteria such as: relevance to the Europe 2020 Strategy, relevance, scope, timescale, evidence-based and potential for learning and replication. Although they were not collected specifically in connection with the Covid-19 crisis, recent examples reflect changes during the pandemic.

In Austria, the practice of "advices for the businesses" (Austria: IBB on demand 2021) offers consulting services to the small and medium-sized enterprises, as well as thr big companies in regards to the COVID 19 pandemic. The areas of consulting include: job protection, training and recruitment. This practice was particularly prevalent in the first lockdown, when face-to-face consultations with employers wr impossible and were carried out either by telephone, intranet, brochures and the Internet. The consultations go through four different phases, as follows:

1. initial consultation;

2. assessment of the current situation in the enterprise;

3. selection of appropriate measures for the specific needs of the employer;

4. providing an approach for implementation of these measures. 
The results of the implementation of this practice show more intensive exchange with the enterprises and an increase in the competencies of the companies for dealing with the situation: preservation of created jobs, training and qualification, transfer of knowledge, etc.

Since the $1^{\text {st }}$ of April 2021 in Lithuania, the Danske Bank has been granting funds to stimulate their employs to work remotely by a computer (the Danske Bank has been giving employees a grant to upgrade their workspace at home 2021). The reason for this program was the presence of two lockdowns in 2020 and from th $16^{\text {th }}$ of Marh 2021 to the $16^{\text {th }}$ of June 2021, which convinced the companies that teleworking is not temporary measure and most companies plan to continue using teleworking after the end of the pandemic. The bank provides an amount of 410 euros per workplace to all the employees willing to work remotely. All the willing employee have been provided with laptops for remote work, and the amount granted by the bank is provided for creating of work environment at home, which will be used for work even after the pandemic. The employer has made a list of companies that sell hardware and furniture at a discount to the bank. Of the approximately 4,000 employees, some 3,200 have applied for the provided by the bank grants.

In Finland, in the first wave of the COVID 19 pandemic due to the lockdown, workers in the restaurant industry were .oosing their jobs because the whole sector was closed $(\mathrm{HOK}$ Elanto transferred 800 employees from restaurants to grocery stores in order to meet the needs of the rapidly changing market 2020). To provide employment, where it was most needed, some 800 workers were redirected to work in supermarkets, where there was an increased pressure and demand for new labour. Since the first lockdown until present, the transfer of workers between the two sectors have been continuesly going on with no final date. These transfers avoid redundancies and dismissals. This practice protects workers from becoming unemployed and receiving unemployment benefits. Instead, they continue to receive the full amount of their salary.

Romania after having introduced changes in its legislation in connection with the first wave of the 2020 COVID 19 pandemic, obliged the employers who cannot provide telework to their employees to apply a phased work schedule Staggered work schedule for companies who cannot apply telework). The measure has targeted companies with more than 50 employees to help eliminate traffic jams on public transport. The measure is effective and is being implemented by most of the organizations within the country. It has also consulted with the social partners.

\subsection{Vocational training/reskilling and upskilling measures}

One of the key areas in the field of active labour market policies is the increase in the activities for qualification and re-qualification of the persons who are the most vulnerable groups on the labour market. In connection with the COVID 19 crisis, the European countries are approaching training and vocational training in various ways. Due to the closure of economies, some countries have decided not to conduct training in the labour market. Others are moving to online training and certification. One of the most important goals of the trainings is to ensure a smooth transition and return to employment, as well as to build new skills for the sectors of the economy that will develop after the end of the crisis. Many of the training programs that have been developed for the classroom are being transformed into online training during the pandemic. At the same time, additional courses are being opened to facilitate access to education and as a direct result of social distancing.

In Spain, public employment services has been offering free training in digital skills. The program started at the end of 2019. Although the trainings are free and accessible to the whole population, they are specifically aimed at SMEs and the unemployed. In addition to the Spanish organization initiator FUNDAE, a network of world-famous companies is included in the program, e.g. such as Amazon Web Services, CISCO, Google and others. With a total of 
567 courses created from the start of the program until October 2021, nearly one million people have visited the platform. The courses are also open to working people. Problems in the implementation of this program are considered to be the need for additional consultation on the choice of courses by those interested and meeting the challenges of including people with less good digital skills.

From March 2020, Greece changeed its legislation in a way that turns its training programs for employed and unemployed people by the use of public entirely to e-distance remote training. All programs co-financed by the EU that require certification of knowledge and skills are given the opportunity to continue to be conducted entirely remotely. On-line certification is performed through the specifications of the National Accreditation System.

The French employment offices offer free access to more than 150 trainings, giving jobseekers access to them and receiving unemployment benefits if they have completed a course provided by the employee services (European Training Foundation, 2021). The courses cover 20 sectors and professions with excellent prospects for development. Companies that implement part-time schemes in the COVID 19 crisis receive a 100\% reimbursement of the costs of training their employees in these courses.

In Sweden, due to the pandemic, aircraft crews are at risk of unemployment (European Training Foundation, 2021). A consortium of public and private companies has been implementing a retraining program for these employees and directing them to the health sector and the social care sector, where the demand for workers is growing rapidly. In cooperation with training companies, Swedish employment offices have developped short five-day internships and online training courses in the agriculture and forestry sectors.

In many employment systems, training is linked to the reduction of workload and aims not only to change the employment sector, but also to create sustainable jobs in connection with the COVID 19 pandemic (European Training Foundation, 2021). Portugal is an example for its efforts to support employment in the SMEs, which make up $99 \%$ of all companies operating. An extraordinary training plan has been developed for those employed in this field, aimed at increasing the professional qualification of employees. Training centers of the labour offices provide the trainings within one month, during which time they have been carried out in regular working hours and are designed with the participation of employers. In the course of the trainings, a funding of the salaries of the employees by public means was provided for those of them, for whom there had been a reduction in the volume of work and suspension of work in connection with the COVID 19 pandemic by up to $50 \%$.

\subsection{Self-employed workers, workers in the informal economy and small and medium-sized enterprises}

Since the beginning of the COVID 19 crisis there has been no substitute for the support of the self-employed, people who have been working in the informal economy and in small and medium-sized enterprises. The reason is that these are groups of people who cannot or do not have a formal reason to seek the support of labour offices. They cannot benefit from shortterm employment schemes, and the social protection provided by social systems is lower than that of other groups of employees. Although many EU countries have announced various packages of measures to support these workers, including direct subsidies, tax and social security deferrals, bank loans and more there are measures that are also applied in the field of active labour market policies.

An example of just such a project that targets these vulnerable groups is a measure that has been introduced in Lithuania. It has been aimed at self-employed people whose activities are specifically affected by the Covid-19 pandemic. The program is active from May to August 2020 and offers 6,950 euros per person affected by Covid-19 to support the launch of another 
activity that, unlike the main one, is not economically affected by the pandemic (Measure to support self-employment for those changing their economic activity 2021).

The measure is aimed at reducing the unemployment of self-employed people who had to quit because of the pandemic. The goal is to redirect them to areas where they can be realized during the crisis, and for this purpose they are allocated up to 7,000 euros to start a new business and purchase equipment. The consultation and approval is done online, and the submission platform is the e-government portal. The funds were provided by the national budget and finance a total of 1,603 applications with 10.4 million euros. The conclusions from the implementation are that the measure is rapidly gaining popularity, even more than expected. This makes it necessary to follow strict criteria for the approval of applications, not allowing the approval of only the first applicants. To receive the grant, applicants must find a job within six months of receiving approval and work in the new job for the next 12 months.

In Malta, as part of a project to train small and medium-sized enterprises after the crisis, the government decided to invest an additional 5 million euro in the very same project (Skills Development Scheme 2020). The name of the project is the Skills Development Scheme, which is offered to small and medium-sized enterprises, micro-enterprises, including the selfemployed. The scheme does not cover trainings such as team building and other activities related to the brand, but includes consulting services to determine the training needs and prepare its program. The additional funds are provided for on-the-spot training in Malta, primarily for companies with up to 50 employees, which lead to the sharing of experiences between older and younger team members.

In Lithuania, in the time of the COVID 19 pandemic, a project for employment of workers in the creative industries was launched (Creative workers employment program 2020). It is characterized by its sectoral and professional orientation, which makes it inapplicable to all self-employed persons, businesses and citizens. The project underwent thourgh several adjustments in connection with the expansion of its scope and improvement for higher efficiency. Funds were provided for a creative project of 1614 euros, but if several criteria are met, related to the restrictions during the pandemic, income received, lack of employment or employment for less than 430 euros per month, as well as the person not to be retired. The project was implemented in the period between July 1 and September 30, 2020. and to expect it to have a lasting effect, which is justified in the submitted documents for a period of 3 years.

\section{Conclusion and recommendations}

The labour market crisis caused by COVID 19 in the EU exceeds initial expectations, which turn out to be more optimistic than in reality. The COVID 19 pandemic is causing an economic shock with extremely negative social consequences. In countries that are neglecting the health crisis, a temporary improvement can be expected. But in the long run, the quality of human capital will deteriorate, and hence the working capacity of the population.

Labour market problems are far from being resolved due to high inflation and the influx of electricity. Small and medium-sized enterprises, which are considered to be the most important source of employment and jobs in the EU, if not supported in this situation, face mass bankruptcies. This, in turn, will reflect on job losses and the employment and income opportunities of many European citizens. At the same time, the likelihood of falling into poverty increases.

In such a situation, labour markets, which traditionally have more developed employment policies, including active ones, are in a better position than EU countries with less developed ones. The European economies will be successful if they are able to offer balanced support to the most vulnerable groups, to the most affected companies and that focus on the long-term recovery of their labour markets, taking into account the green and digital transition. The most effective are the interventions of the countries with a well-developed mix of active 
labour market policies and a strategic vision for the use of financial support for the pandemic in this area. They are an example of the rapid adaptation of measures already in place and their subsequent implementation. The frequent transitions made by people of working age and the dynamics of economic processes place demands for greater flexibility and adaptability of the active labour market policies themselves.

The public employment services with their capacity and capacity to develop, monitor and evaluate active labour market policies, provide mediation services and target the most vulnerable groups and individuals must also develop in parallel with the development of labour markets. A negative finding by the Organization for Economic Co-operation and Development is that those most in need of labour offices during the pandemic were in fact the least in contact with them. The most important challenges for employment offices will be to reach young people, the self-employed, to shed light on the informal economy and to attract small and medium-sized enterprises as users of employment services.

The channels of contact with the citizens have been cut off and considerable time and effort must be invested in communicating with them, so that they can be convinced of the usefulness of the support and be assisted in the most difficult moments when looking for a job and meeting basic needs.

Given how difficult it is to reform public institutions, the external pressure in countries with underdeveloped e-services can even be seen as a positive thing. However, the success of e-services can be called upon question. How sustainable it will be over time and after the COVID 19 pandemic depends on whether the requirements for distance and protection from the pandemic were its only source. If permanent changes have been made during the crisis in the functions performed and the technology of activating the labour offices, the chances for that increase.

The COVID 19 pandemic has become part of everyday life for more than a year after was firstly discovered. However, what remains constant is the aging population in EU countries. This makes it critical for the faster and more dynamic development of skills to work in organizations and to link them to future transformations in European economies, as well as to prevent gaps in education and the provision of employment opportunities. Europe supports the efforts of Member States at national level to build skilled human capital and to develop modern integrated strategies for improving skills and lifelong learning.

The presented plans for resilience and recovery, as well as projects in the field of obtaining of skills prove that the labour markets need modern forms of training related to the new professional knowledge, skilss and competences, and not only in time of economic booms, but also times of a crisis when there is more personal free time for training and qualification.

What successful projects in the active policies at the European labour markets have in common is that they take into account the gaps in the market mechanism, legislation and seek to offer flexible support to participating companies and individuals, tailored to their current needs and problems, so as to maintain their ability to work and develop new opportunities. They provide preservation of the health and working capacity of the beneficiaries, as well as opportunities for adaptive employment. 


\section{References}

Chiodi, Fr. M. (2020, December 16). Transforming active employment policies for an inclusive recovery involving work. Retrieved from https://eurosocial.eu/en/reciprocamente/transformar-las-politicas-activas-de-empleopara-una-recuperacion-inclusiva-y-con-trabajo/.

European Commission. (2021). Commission Recommendation (EU) 2021/402 of 4 March 2021 on an effective active support to employment following the COVID-19 crisis (EASE). Retrieved from https://eur-lex.europa.eu/legalcontent/EN/TXT/PDF/?uri=CELEX:32021H0402\&from=EN.

European Commission. (2020, October). Austria: IBB on demand. Retrieved from https://ec.europa.eu/social/BlobServlet?docId=24835\&langId=en.

European Commission. (2020, May 25). European Semester: Recommendations for a coordinated response to the coronavirus pandemic. Employment, Social Affairs \& Inclusion. Retrieved from https://ec.europa.eu/social/main.jsp?catId=89\&furtherNews=yes\&langId=en\&newsId $=9685$.

European Commission. (2020). European Skills Agenda. Retrieved from https://ec.europa.eu/social/main.jsp?catId=1223\&langId=en.

European Commission. (2020, October) Spain: Free training in digital skills. Retrieved from https://www.cedefop.europa.eu/en/news/spain-promotion-training-digital-skills$\underline{\text { workers. }}$

European Commission. (n.d.). The European instrument for temporary Support to mitigate Unemployment Risks in an Emergency (SURE). Retrieved from https://ec.europa.eu/info/business-economy-euro/economic-and-fiscal-policycoordination/financial-assistance-eu/funding-mechanisms-and-facilities/sure_en.

European Commission. (2021, January). Lithuania: Measure to support self-employment for those changing their economic activity. Retrieved from https://ec.europa.eu/social/BlobServlet?docId=23517\&langId=en.

European Commission. (2021). PES Practices. Employment, Social Affairs \& Inclusion. Retrieved from https://ec.europa.eu/social/main.jsp?catId=1206\&langId=en.

European Commission. (2020). Science for policy brief: Telework in the EU before and after the COVID-19: where we were, where we head to. Retrieved from https://ec.europa.eu/jrc/sites/default/files/jrc120945_policy_brief_covid_and telework_final.pdf.

European Training Foundation. (2021). Mapping innovative practices in the field of active labour market policies during the Covid-19 crisis. Retrieved from https://www.etf.europa.eu/sites/default/files/202110/almps_innovative_practices_during_covid-19_0.pdf. 
Eurofound. (2021). COVID-19 EU Policy Watch. Database of national-level responses. Retrieved from https://static.eurofound.europa.eu/covid19db/index.html.

Eurofound. (2021). Danske Bank gives employees a grant to upgrade their workspace at home, case LT-2021-14/1862 (measures in Lithuania). COVID-19 EU PolicyWatch. Dublin. Retrieved from https://static.eurofound.europa.eu/covid19db/cases/LT-2021$\underline{14 \_1862 . \mathrm{html}}$

Eurofound. (2021, September 17). About COVID-19 EU PolicyWatch. Retrieved from http://eurofound.link/covid19eupolicywatch

Eurofound. (2020). HOK-Elanto transferred 800 employees from restaurants to grocery stores in order to meet the needs of the rapidly changing market, case FI-202012/1353 (measures in Finland). COVID-19 EU PolicyWatch. Dublin. Retrieved from http://eurofound.link/covid19eupolicywatch.

Eurofound. (2020). Staggered work schedule for companies who can't apply telework, case RO-2020-45/1433 (measures in Romania). COVID-19 EU PolicyWatch, Dublin. Retrieved from http://eurofound.link/covid19eupolicywatch.

Eurofound. (2020). Distance learning introduced for public training programmes, case GR2020-11/693 (measures in Greece). COVID-19 EU PolicyWatch. Dublin. Retrieved from http://eurofound.link/covid19eupolicywatch.

Eurofound. (2020). Skills Development Scheme, case MT-2020-24/936 (measures in Malta). COVID-19 EU PolicyWatch. Dublin. Retrieved from http://eurofound.link/covid19eupolicywatch.

Eurofound. (2020). Creative workers employment program, case LV-2020-27/1334 (measures in Latvia). COVID-19 EU PolicyWatch. Dublin. Retrieved from http://eurofound.link/covid19eupolicywatch.

European Union. (2021, March 4). Questions and Answers: Effective Active Support to Employment following the COVID-19 crisis (EASE). Retrieved from https://ec.europa.eu/commission/presscorner/detail/it/qanda_21_971.

European Union. (2021, June 17). NextGenerationEU: European Commission endorses Greece's $€ 30.5$ billion recovery and resilience plan. Retrieved from https://europeansting.com/2021/06/17/nextgenerationeu-european-commissionendorses-greeces-e30-5-billion-recovery-and-resilience-plan/.

Eurostat. (2021, May). Culture statistics - cultural employment. Retrieved from https://ec.europa.eu/eurostat/statistics-explained/index.php?title=Culture_statistics _cultural_employment\#Cultural_employment_E2.80.94_overall_developments.

Eurostat. (2021, December 1). Employment and activity by sex and age - quarterly data. Retrieved from https://ec.europa.eu/eurostat/databrowser/view/lfsi_emp_q/default/table?lang=en. 
Eurostat. (2020, April). Statisctics explained: Absences from work - quarterly statistics.

Retrieved from https://ec.europa.eu/eurostat/statistics-

explained/index.php?title=Archive:Absences_from_work_-_quarterly_statistics.

NextgenerationEU. (2021, June). Spain's recovery and resilience plan European Union.

Retrieved from https://ec.europa.eu/info/business-economy-euro/recovery-

coronavirus/recovery-and-resilience-facility/spains-recovery-and-resilience-plan_en

OECD. (2021). Employment Outlook 2021: Navigating the COVID-19 Crisis and Recovery. OECD Publishing. Paris. https://doi.org/10.1787/5a700c4b-en.

OECD. (2021, July 15). Designing active labour market policies for the recovery, In Tackling Coronavirus (COVID-19): Contributing to a Global Effort. Retrieved from https://read.oecd-ilibrary.org/view/?ref=1100_1100299-

wthqhe00pu\&title=Designing-active-labour-market-policies-for-the-recovery. 